\author{
Universidade de São Paulo \\ Faculdade de Filosofia Ciências e Letras de Ribeirão Preto \\ Departamento de Biologia \\ Programa de Pós-Graduação em Entomologia
}

\title{
"Efeito da fermentação induzida sobre o valor nutritivo de dietas proteicas para abelhas Apis mellifera"
}

Joyce Mayra Volpini de Almeida

Dissertação apresentada à Faculdade de Filosofia, Ciências

e Letras de Ribeirão Preto da USP, como parte das exigências para a obtenção do título de Mestre em Ciências, Área: Entomologia.

RIBEIRÃO PRETO - SP

2013 


\author{
Universidade de São Paulo \\ Faculdade de Filosofia Ciências e Letras de Ribeirão Preto \\ Departamento de Biologia \\ Programa de Pós-Graduação em Entomologia
}

\title{
"Efeito da fermentação induzida sobre o valor nutritivo de dietas proteicas para abelhas Apis mellifera"
}

\author{
Joyce Mayra Volpini de Almeida
}

Orientador: Prof. Dr. David de Jong Dissertação apresentada à Faculdade de Filosofia, Ciências e Letras de Ribeirão Preto da USP, como parte das exigências para a obtenção do título de Mestre em Ciências, Área: Entomologia.

RIBEIRÃO PRETO - SP

2013 
AUTORIZO A REPRODUÇÃO E DIVULGAÇÃO TOTAL OU PARCIAL DESTE TRABALHO, POR QUALQUER MEIO CONVENCIONAL OU ELETRÔNICO, PARA FINS DE ESTUDO E PESQUISA, DESDE QUE CITADA A FONTE.

FICHA CATALOGRÁFICA

Almeida, Joyce Mayra Volpini de

Efeito da fermentação induzida sobre o valor nutritivo de dietas proteicas para abelhas Apis mellifera. Ribeirão Preto, 2013.

93 p.:36 il. $30 \mathrm{~cm}$

Dissertação de Mestrado apresentada à Faculdade de Filosofia Ciências e Letras de Ribeirão Preto/USP - Área de concentração: Entomologia.

Orientador: De Jong, David

Palavras chaves: Apis mellifera; nutrição de abelhas; dietas artificiais; fermentação. 


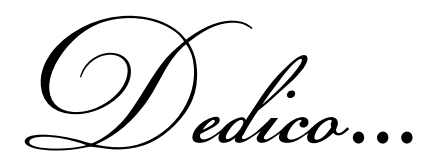

Aos meus amados pais, Que são à base da minha vida!

Pelo amor dado, pelos estudos, Pela dedicação e confiança depositada em mim! Amo vocês incondicionalmente! 


\section{Q $/$ Gradecimentos...}

Ao longo desses anos, observei, escutei e aprendi muitas coisas que a vida e pessoas muito especiais puderam me mostrar. Todos os caminhos trilhados pelo qual passei e passarei são os frutos de um trabalho acadêmico feito em conjunto com Deus e pessoas maravilhosas. Espero que cada um sinta tocado por minhas palavras, pois são sinceras e do fundo do coração! Portanto agradeço...

Ao meu amado senhor Jesus Cristo, para quem oro todos os dias, agradecendo todas as bênçãos que Ele proporcionou em minha vida.

A minha linda irmã Letícia Volpini, pela amizade e pelo amor que temos uma com a outra. Você sempre terá um lugar no meu coração Lulinha!

Ao amor da minha vida, meu futuro marido, Eduardo, com quem posso contar em todos os momentos. Meu amigo, meu amado! Obrigada por ser paciente e me escutar sempre que eu preciso! Te amo para toda a vida!!

Ao Prof. Dr. David de Jong, por ter me acolhido e orientado ao longo desses anos.

A Yara S. R. Sbordoni, mais que amiga. Que me ajudou e me ajuda sempre que preciso... Com seus conselhos e conversas prazerosas!! Sem você amiga, não estaria aqui! Te adoro muitão!

A minha companheira de mesa, de início de mestrado, Clycie. Te adoro demais, você sempre estará guardadinha no meu coração, viu! E vamos pra mais uma etapa juntas!

Ao querido amigo, Rogério Ap. Pereira, por ser um amigo inigualável! Por me ajudar sempre que preciso, tanto pessoalmente quanto profissionalmente...Sem você Rô, nada teria dado certo! E por ser essa pessoa tão abençoada por Deus! Obrigada por ser tão maravilhoso comigo...

A Aline P. Turcatto, minha amiga-irmã. Como dizemos: nos conhecemos a mil anos, pois não é possível nos darmos tão bem!! Obrigada por entrar em minha vida e fazer com que ela se tornasse muito mais divertida! Obrigada pelos ensinamentos e 
ajuda! Muito obrigada pela parceria em tudo, afinal somos o trio da nutrição (Mi, Aline e Joyce), lembra? Te amo muito fubazinha!!

A Michelle M. M. Vátimo, por tudo que vem me ensinado desde quando entrei no mundo das abelhas! Por ter me mostrado como é gostoso e prazeroso nossa profissão! Obrigada por tudo, pelos conselhos e pela amizade que eu zelo com todo meu amor! Você já faz parte dos meus caminhos e minhas conquistas!!!

Ao Prof. Dr. Tiago M. Francoy, pela ajuda e sugestões maravilhosas durante todo o percurso deste trabalho.

Ao amigos do APILAB: Juliana S. G. Teixeira, a baininha doidinha Daiana Almeida (que saudade, volta logo!), Hipólito F. P. Neto, Patrícia Pinhal, Adriana Gerosa, Marcia Issa, Caroline Moretti e tantos outros que passaram por lá e deixaram sua marca. Valeu pessoal por tudo!

Aos professores Zilá L. P. Simões, Lionel S. Gonçalves, Fábio S. Nascimento, pelo apoio em seus laboratórios e pelos ensinamentos.

Ao pessoal do Bloco A: Vera Figueiredo, Karina L. G. Lazzarini, Vanessa Bonatti, Claudinéia P. Costa, Ana Rita Baptistela, Mauro Prato, pela atenção, amizade e grande ajuda no decorrer desses anos.

Aos técnicos Luis Roberto Aguiar e Sr. Pedro, pelos auxílios prestados durante a fase de coleta de dados deste trabalho.

A Renata A. Cavallari e a Vera, secretárias do Programa de Pós-Graduação em Entomologia, pela ajuda e paciência sempre que precisei!

A Susie Nalon e a Silvia, secretárias do Programa de Pós-Graduação do Departamento de Genética, pela atenção e ajuda em todos os momentos!

Ao Programa de Pós-Graduação em Entomologia pelos materiais concedidos.

Ao Departamento de Biologia da Faculdade de Filosofia Ciências e Letras de Ribeirão Preto.

Ao CNPq, pelo auxílio financeiro durante a realização deste trabalho. 


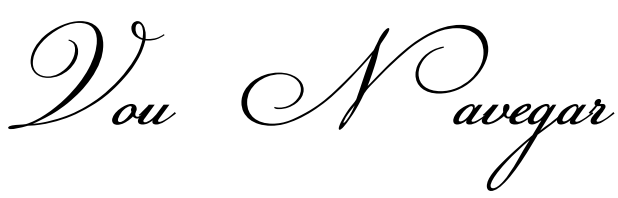

Carlos Alberto Tolovi

Outra vez me vejo só, com meu Deus

Não consigo mais fugir, fugir de mim

Junto às águas deste mar vou lutar

Hoje quero me encontrar

Buscar o meu lugar

Vou navegar, nas águas deste mar

Navegar... eu quero me encontrar

Navegar... não posso mais fugir

Vou procurar, nas águas mais profundas

No mar... feliz eu vou seguir

Só amar, buscar o meu lugar

Sem dúvidas, sem medo de sonhar!

Ó Jesus, com fé eu te seguirei

Só contigo sou feliz, tu és em mim!

Teu Espírito de amor criador

Me sustenta no meu sim

Me lança neste mar!

Vivo a certeza desta missão

Já não posso desistir, voltar atrás

Mãe Maria, vem tomar minha mão

E me ajuda a ser fiel

Só Cristo é luz e paz! 


\section{SUMÁRIO}

LISTA DE FIGURAS..........................................................................

LISTA DE TABELAS................................................................................v

RESUMO ...................................................................................................

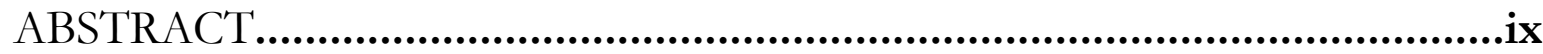

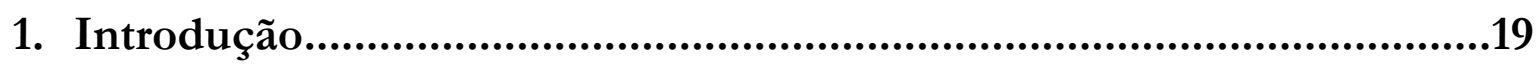

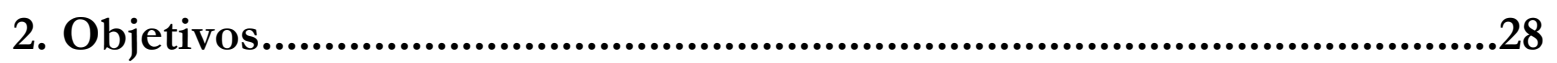

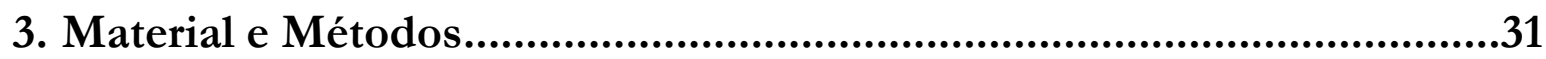

3.1. Local de estudo e escolha do material...............................................32

3.2. Utilização de diferentes métodos para determinar a eficiência das dietas proteicas artificiais em abelhas africanizadas mantidas em laboratório...32

3.2.1. Fermentação do Inoculo através do Beebread............................32

3.2.2. Procedimento Experimental..................................................35

3.2.3. Determinação da concentração de proteína total na hemolinfa de operárias confinadas em gaiola.................................................38

3.2.4. Padrão eletroforético para proteínas totais.................................40

3.2.5. Avaliação da taxa de sobrevivência de abelhas operárias adultas confinadas em laboratório..................................................41

3.2.6. Determinação da taxa de consumo e preferência de cada dieta no

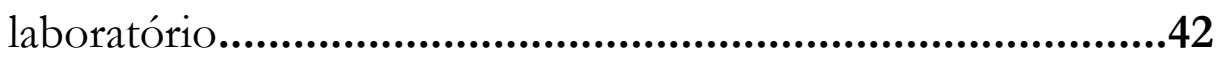

3.3. Determinação da eficiência de dietas proteicas em colônias de abelhas africanizadas. .42

3.3.1. Monitoramento dos pesos das colônias. 
3.3.2. Mapeamento da área de cria....................................................45

3.3.3. Determinação da taxa de consumo e preferência de cada dieta o no campo...........................................................................47

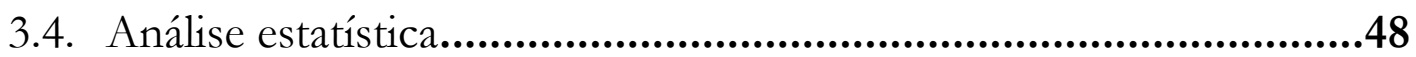

4. Resultados e Discussão.......................................................................49

4.1. Determinação da concentração de proteína total na hemolinfa de operárias confinadas em gaiola..........................................................50

4.2. Padrão eletroforético para proteínas totais.......................................56

4.3. Avaliação da taxa de sobrevivência de abelhas operárias adultas confinadas em laboratório..........................................................61

4.4. Determinação da taxa de consumo e preferência de cada dieta..........64

4.4.1. $\quad 1^{\mathrm{o}}$ Experimento: Laboratório......................................................64

4.4.2. $\quad 2^{\circ}$ Experimento: Campo...............................................................66

4.5. Determinação da eficiência de dietas proteicas em colônias de abelhas africanizadas no campo através do monitoramento, peso e mapeamento.................................................................................68

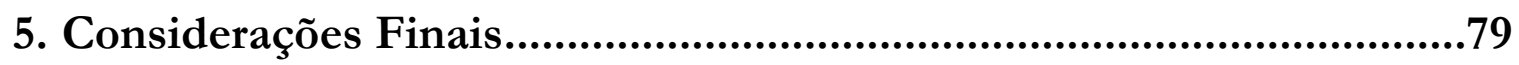

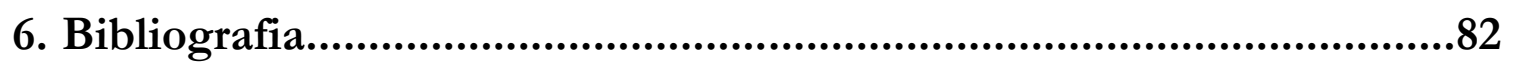




\section{Lista de Figuras}

Figura 1. Apiário experimental do Departamento de Genética da Faculdade de Medicina de Ribeirão Preto - USP.

Figura 2. Placa de petri esterilizada contendo "Beebread" retirado dos favos................33

Figura 3. Frasco reagente em vidro borosilicato incolor com a mistura de Beebread e

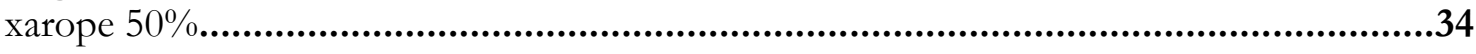

Figura 4. Isca fermentada (10 gramas de "Beebread" com $300 \mathrm{~mL}$ de xarope de sacarose) após 28 dias na estufa, com aspecto líquido e formação de bolhas.....................35

Figura 5. Gaiola plástica de confinamento contendo 100 operárias recém-emergidas. (A) container plástico com abertura frontal contendo o alimento proteico; (B) Recipiente

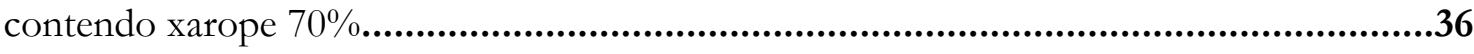

Figura 6. Recipiente plástico (tubo falcon $50 \mathrm{~mL}$ cortado na metade) utilizado para introduzir as dietas nas gaiolas plásticas de confinamento, para alimentar as abelhas

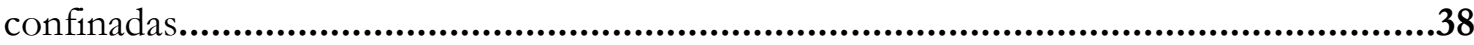

Figura 7. Hemolinfa de operária sendo coletada com a ajuda de uma micropipeta........39

Figura 8. Placa de Elisa com curva padrão de albumina (BSA) e amostras com reagente de Bradford.

Figura 9. A - Espectrofotômetro utilizado para a leitura da quantificação proteica; B Placa de Elisa sendo colocada no espectrofotômetro para a leitura

Figura 10. Núcleos padronizados dispostos em balanças digitais.................................43

Figura 11. Núcleo disposto sobre balança digital dotada de sensores...........................44

Figura 12. Painéis eletrônicos dispostos na parte interna do laboratório, indicando os pesos das balanças que se encontram localizadas no apiário.

Figura 13. A - Quadro de alimento (pólen e néctar) sendo mapeado; B - Quadro de cria sendo mapeado.... .46

Figura 14. Suporte de madeira com laterais construídas de arame esticado, formando quadrados de $5 \mathrm{~cm}$ de lado.

Figura 15. Níveis de proteína na hemolinfa $(\mu \mathrm{g} / \mu \mathrm{l})$ das abelhas recém-nascidas alimentadas com as diferentes dietas durante três dias. . .51

Figura 16. Níveis de proteína na hemolinfa $(\mu \mathrm{g} / \mu \mathrm{l})$ das abelhas alimentadas com as diferentes dietas no período de sete dias.

Figura 17. A - Comparação ( $\mu \mathrm{g}$ de proteína por $\mu \mathrm{l}$ de hemolinfa) entre o Controle Positivo (D1) e as dietas (Controle Negativo - D2; D3 e D4) com 3 dias de alimentação; Comparação entre o Controle Positivo (D1) e as dietas (Controle Negativo - D2; D3 e D4) com 7 dias de alimentação. 
Figura 18. A - Comparação ( $\mu \mathrm{g}$ de proteína por $\mu \mathrm{l}$ de hemolinfa) entre o Controle Negativo (D2) e as dietas (Controle Positivo - D1; D3 e D4) com 3 dias de alimentação; Comparação entre o Controle Negativo (D2) e as dietas (Controle Positivo - D1; D3 e D4) com 7 dias de alimentação.

Figura 19. Comparação ( $\mu$ g de proteína por $\mu \mathrm{l}$ de hemolinfa) entre a dieta fermentada (D4) e a Dieta não fermentada (D3) com sete dias de alimentação.

Figura 20. Gel de poliacrilamida SDS-PAGE corado com Coomassie Brillant Blue, mostrando padrões de proteína na hemolinfa de operárias de abelhas A. mellifera alimentadas com diferentes dietas: Xarope (Controle Negativo); "Beebread" (Controle Positivo), dieta fermentada (D4) e dieta não fermentada (D3). Marcadores de massa molecular $(\mathrm{kDa})$ estão indicadas à direita. .57

Figura 21. Bandas de Vitelogenina em abelhas alimentadas durante sete dias, em gel SDS-PAGE. Gel padronizado no volume aplicado de amostras de hemolinfa. D1 (Controle Positivo); D2 (Controle Negativo - Xarope de Sacarose); D3 (Dieta não fermentada); D4 (Dieta fermentada) . .58

Figura 22. Quantificação densitométrica da intensidade de bandas correspondentes à vitelogenina em abelhas alimentadas com a dieta não fermentada (D3) e a dieta fermentada (D4) em gel SDS-PAGE.

Figura 23. Bandas de Lipoforina em abelhas alimentadas durante sete dias, em gel SDSPAGE. Gel padronizado no volume aplicado de amostras de hemolinfa. D1 (Controle Positivo); D2 (Controle Negativo - Xarope de Sacarose); D3 (Dieta não fermentada); D4 (Dieta fermentada) .60

Figura 24. Quantificação densitométrica da intensidade de bandas correspondentes à lipoforina em abelhas alimentadas com a dieta não fermentada (D3) e a dieta fermentada (D4) em gel SDS-PAGE.

Figura 25. Média da quantidade de abelhas sobreviventes alimentadas com as diferentes dietas em gaiola de confinamento. D1: controle positivo; D2: controle negativo; D3: dieta não fermentada; D4: dieta fermentada

Figura 26. Comparação das médias taxas de consumo (peso em gramas) entre as dietas D3 (dieta não fermentada) e D4 (dieta fermentada) em gaiolas de confinamento. .65

Figura 27. Comparação das médias taxas de preferência (peso em gramas) entre as dietas D3 (dieta não fermentada) e D4 (dieta fermentada) em gaiolas de confinamento. .66

Figura 28. Comparação das médias taxas de consumo (peso em gramas) entre as dietas D3 (dieta não fermentada) e D4 (dieta fermentada) no campo durante 7 dias. .67

Figura 29. Comparação das médias taxas de preferência (peso em gramas) entre as dietas D3 (dieta não fermentada) e D4 (dieta fermentada) em colônias no campo. .68 
Figura 30. Núcleo 1, alimentado com a dieta D3 (dieta não fermentada), no qual estão representados os dados coletados (\% de área total de favo disponível) através de um mapeamento realizado quinzenalmente referente à quantidade de células dos favos de cria operculada (CO), quantidade de células dos favos de cria aberta (CA) e peso do núcleo, que foi monitorado por balanças digitais.

Figura 31. Núcleo 2, alimentado com a dieta D3 (dieta não fermentada), no qual estão representados os dados coletados (\% de área total de favo disponível) através de um mapeamento realizado quinzenalmente referente à quantidade de células dos favos de cria operculada (CO), quantidade de células dos favos de cria aberta (CA) e peso do núcleo, que foi monitorado por balanças digitais.

Figura 32. Núcleo 3, alimentado com a dieta D4 (dieta fermentada), no qual estão representados os dados coletados (\% de área total de favo disponível) através de um mapeamento realizado quinzenalmente referente à quantidade de células dos favos de cria operculada (CO), quantidade de células dos favos de cria aberta (CA) e peso do núcleo, que foi monitorado por balanças digitais

Figura 33. Núcleo 4, alimentado com a dieta D4 (dieta fermentada), no qual estão representados os dados coletados (\% de área total de favo disponível) através de um mapeamento realizado quinzenalmente referente à quantidade de células dos favos de cria operculada (CO), quantidade de células dos favos de cria aberta (CA) e peso do núcleo, que foi monitorado por balanças digitais

Figura 34. Núcleo 5, colônia controle, no qual estão representados os dados coletados (\% de área total de favo disponível) através de um mapeamento realizado quinzenalmente referente à quantidade de células dos favos de cria operculada (CO), quantidade de células dos favos de cria aberta (CA) e peso do núcleo, que foi monitorado por balanças digitais.

Figura 35. Núcleo 6, colônia controle, no qual estão representados os dados coletados (\% de área total de favo disponível) através de um mapeamento realizado quinzenalmente referente à quantidade de células dos favos de cria operculada (CO), quantidade de células dos favos de cria aberta (CA) e peso do núcleo, monitorado por balanças digitais

Figura 36. Área de cria total (cria operculada e cria aberta) dos núcleos analisados através do mapeamento quinzenal. Núcleos 1 e 2: alimentados com a dieta D3 (não fermentada); Núcleos 3 e 4: alimentados com a dieta D4 (fermentada); Núcleos 5 e 6: não alimentados com nenhuma dieta artificial (controle) 


\section{Lista de Tabelas}

Tabela 1. Dietas energético-proteicas elaboradas e fornecidas às operárias de abelhas

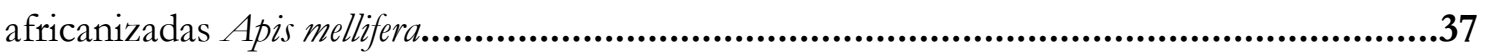

Tabela 2. Médias da taxa de sobrevivência de operárias de abelhas $A$. mellifera confinadas e alimentadas com diferentes dietas energético-proteicas.................................................62 
Sog Posumo 


\section{RESUMO}

Através da coleta de pólen, néctar e água as abelhas sociais conseguem suprir as exigências nutricionais para a manutenção da colônia e crescimento das crias. Esses insetos necessitam de reservas de alimento suficientes para atender a seu próprio sustento e das crias em desenvolvimento. Se tiver falta de alimento disponível na natureza, as colmeias enfraquecem. A carência de pólen no campo tem se tornado um grande problema para os apicultores. Uma alimentação artificial que suplemente essa carência ajuda a diminuir as perdas em épocas críticas. Porém, para que essa alimentação seja eficaz tanto quanto a alimentação natural, essas dietas artificiais devem suprir as necessidades nutricionais, e serem palatáveis a essas abelhas. O objetivo do nosso trabalho foi desenvolver e testar, uma dieta que seja o mais próximo possível da realidade dessas abelhas, ou seja, próximo ao "Beebread" - pão da abelha, em relação à palatabilidade e ao valor nutricional. Os experimentos foram realizados no Apiário Experimental do Departamento de Genética da Faculdade de Medicina de Ribeirão Preto - USP com colmeias de abelhas Africanizadas (Apis mellifera). Foi produzido um inóculo fermentado à base dos microrganismos que ocorrem naturalmente no "Beebread" para que posteriormente pudesse ser usado para fermentar a dieta proteica artificial. Para tal, foram adicionamos 10 gramas de "Beebread" recém-coletado dos favos de uma colmeia, a $300 \mathrm{~mL}$ de xarope de sacarose 50\% (v/v) em frasco de vidro, com tampa solta para permitir saída de gás da fermentação. Após 28 dias de armazenamento em estufa $\left(35^{\circ} \mathrm{C}\right)$, notou-se o surgimento de várias bolhas na superfície, indicando a produção do gás carbônico. Para os testes em laboratório, 100 abelhas recém-emergidas foram coletadas e introduzidas em gaiolas de confinamento, onde foram alimentadas por um período de sete dias com as dietas D1, (controle positivo mistura de $5 \mathrm{~g}$ de "Beebread" e $4 \mathrm{~mL}$ de água), dieta D2 (controle negativo - xarope de sacarose 70\%), dieta D3 (Dieta proteica) ou Dieta D4 (Dieta proteica fermentada). A dieta proteica consistiu de $20 \mathrm{~g}$ de levedura de cana, 16,7 $\mathrm{g}$ de farinha de soja, 43,3 g de farelo de arroz, e $20 \mathrm{~g}$ de sacarose. Foram feitas oito repetições desse experimento. Verificamos as taxas de consumo e preferência das dietas D3 e D4, através de medições dos pesos das sobras de cada dieta. A taxa de sobrevivência foi analisada contando-se as abelhas sobreviventes durante o período de 28 dias. Foi retirada amostras de hemolinfa de 20 abelhas confinadas nas gaiolas, para a análise da concentração proteica utilizou-se o método descrito por Bradford e leitura em um espectrofotômetro. Realizamos testes qualitativos através de gel SDS-PAGE corado com Coomassie Brilliant Blue, onde detectamos as bandas das principais proteínas, como a Vitelogenina (Vg) e Lipoforina (Lp). Para testes no campo, foram utilizados seis núcleos padronizados e dispostos em balanças digitais. Dois núcleos foram alimentados durante 60 dias com a dieta D3 e dois núcleos com D4 (100 g por semana); os dois núcleos restantes não receberam alimentação suplementar. Avaliamos mudanças no peso dessas colônias, a área de cria aberta (CA), a área de cria operculada (CO) e o consumo de cada dieta. Para os testes de preferência, foram escolhidos três núcleos, onde as dietas D3 e D4 foram oferecidas simultaneamente ( $50 \mathrm{~g}$ de cada dieta). O peso da sobra dessas dietas foi medido de dois em dois dias e anotado para análises posteriores. Após três dias de alimentação, não havia diferença estatística entre as dietas proteicas comparado ao controle positivo, $\mathrm{p}=0,809$ e $\mathrm{p}=0,437$, respectivamente no parâmetro quantidade de proteína na hemolinfa. Em relação ao controle negativo as duas dietas (D3 e D4) e o controle positivo foram significativamente superiores $(p=0,007)$. Já com sete dias de 
alimentação, verificou-se que tanto a dieta D3 quanto a dieta D4, foram significativamente inferiores ao controle positivo ( $\mathrm{s} \leq 0,001$ e $p=0,007$, respectivamente). A dieta D4 foi significativamente superior à dieta D3 $(p=0,021)$ no parâmetro proteína na hemolinfa. Através da análise da densitometria das bandas do gel, observamos que a Dieta D4 resultou em significativamente mais proteína em relação à Dieta D3 ( $\mathrm{p}=0,0027)$. Ao observarmos a densitometria das bandas de Lp, verificamos que não houve diferença estatística entre estas duas dietas ( $p=0,927)$. A taxa de sobrevivência das abelhas que se alimentaram das dietas D1, D3 e D4 foi significativamente superior à sobrevivência das abelhas alimentadas somente com sacarose (D2), ( $\leq \leq 0,001)$. Para este parâmetro não houve diferença significativa entre as dietas artificiais (D3 e D4) e o controle positivo (D1) ( $p=0,188)$. O consumo da dieta D4 foi significativamente superior em relação ao consumo da dieta D3 ( $p=0,002)$. Em relação à preferência, houve a mesma tendência observada para o consumo $(\mathrm{p} \leq 0,001)$. No campo, a dieta D4 foi mais consumida do que à dieta D3 ( $\mathrm{p} \leq 0,001)$. Não encontramos diferenças na preferência para as duas dietas $(p=0,850)$. Verificamos que o núcleo 1, (alimentado com a dieta D3), obteve um aumento não significante em relação a área de $\mathrm{CA}$ e $\mathrm{CO}, \mathrm{p}=0,100$. Em relação ao núcleo 2, (alimentado com a dieta D3), notamos um pequeno aumento, porém não significativo $(\mathrm{p}=0,12)$ na área total de cria depois dos primeiros 15 dias. Porém mesmo com a alimentação artificial (Dieta D3), houve uma enxameação por abandono. No núcleo 3, (alimentado com a dieta D4), houve um aumento significante, de CA. O núcleo 4, alimentado com a dieta D4, aumentou de peso, sendo necessário passar de núcleo para ninho. No núcleo 5 (grupo controle), houve uma queda brusca de $\mathrm{CO}$ no $45^{\circ}$ dia para o $60^{\circ}$ dia, sendo que esta colônia no final do mapeamento continuou com a mesma quantidade de $\mathrm{CO}$ que no início. No núcleo 6 (grupo controle), podemos observar que essa colônia sofreu várias oscilações referente as áreas de cria, porém não houve diferenças no final do experimento. Concluímos que em épocas de escassez alimentar, dietas artificiais proteicas fermentadas, além de serem mais palatáveis as abelhas, aumentam a quantidade de proteína no hemolinfa e a quantidade cria na colmeia. 


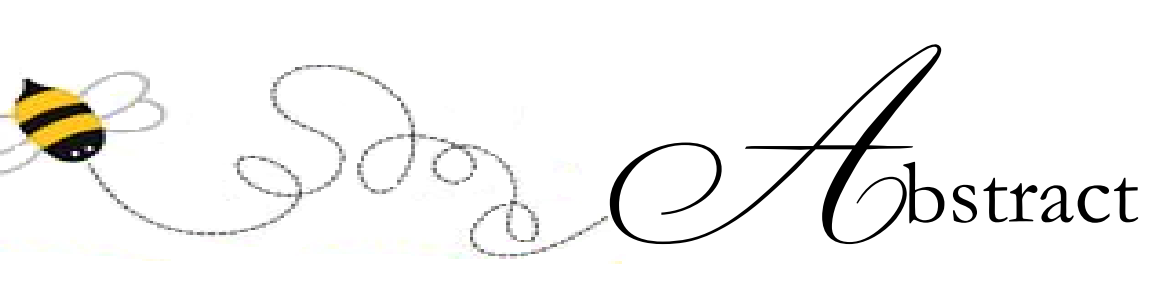




\section{ABSTRACT \\ The effect of induced fermentation on the nutritional value of artificial protein diets fed to honey bees}

By collecting pollen, nectar and water, social bees are able to take care of their nutritional needs for colony growth and maintenance. Adult bees need sufficient food reserves for their own sustenance and to produce brood. If there is a lack of food in nature, the colonies weaken rapidly. Pollen is their only source of protein, lipids, minerals and vitamins. A lack of pollen in the field is becoming a major problem for beekeepers. An artificial diet supplement can overcome this lack of natural food and help reduce losses during critical periods. However, in order for this type of diet to be as effective as natural food sources, these artificial diets need to supply all nutritional necessities and also be palatable for the bees. Our objective was to develop and test a diet that is as close as possible to the natural food of the bees (beebread) in terms of palatability and nutritional value. It also needed to be of low cost so that the beekeeper could afford to use it in his apiaries. The experiments were conducted with Africanized honey bees (Apis mellifera). An inoculum was prepared from beebread. We added $10 \mathrm{~g}$ of recently harvest beebread to $300 \mathrm{~mL}$ of $50 \%(\mathrm{v} / \mathrm{v})$ sucrose syrup in a sterilized glass bottle, that was loosely capped in order to allow the fermentation gasses to escape. After 28 days in an incubator $\left(35^{\circ} \mathrm{C}\right)$, we noted that bubbles had formed on the surface of the diet, indicating $\mathrm{CO} 2$ production. The diets were tested in the laboratory in small cages filled with 100 recently emerged adult worker bees. The cages were maintained in a dark incubator at $34^{\circ} \mathrm{C}$ during seven days and fed with beebread, sucrose syrup, protein diet, or fermented protein diet. The protein diet consisted of $20 \mathrm{~g}$ of cane sugar alcohol yeast, $16.7 \mathrm{~g}$ soy flour, $43.3 \mathrm{~g}$ rice meal, and $20 \mathrm{~g}$ sucrose. Eight repetitions were made for each of these diets. We examined the consumption and preference for the fermented and unfermented protein diets by weighing the unconsumed diet. The survival rate was determined during 28 days in the cages. Hemolymph was collected from 20 bees from each cage for the protein content analysis, using the Bradford assay, with a spectrophotometer. Qualitative analyses were made of the proteins in the hemolymph with an SDS-PAGE gel stained with Coomassie Brilliant Blue; the main comparison was of the storage proteins vitellogenin and lipophorin. Field tests of the diets were made with five frame nucleus colonies maintained on digital scales. The colonies were fed for 60 days on fermented or unfermented protein diet (100 g/week), or no supplement (control). The colony weight, open brood area, sealed brood area and diet consumption were measured. Two colonies were tested for each diet condition. Preference tests were run with the fermented and unfermented protein diets (50 g each) in three nucleus colonies. After feeding for three days, the caged-bee hemolymph protein levels were similar in the comparison between the two protein diets and the beebread diet $(\mathrm{p}=0.809$ and $\mathrm{p}=0.437)$. Both artificial diets were superior to sucrose alone $(p=0.007)$. After feeding for seven days, both protein diets were inferior to beebread ( $\mathrm{p} \leq 0.001$ and $\mathrm{p}=0.007)$. However, the fermented diet was superior to 
the unfermented protein diet $(\mathrm{p}=0.021)$. In the analysis of proteins in the protein separation gel, the fermented diet gave more protein than the unfermented protein diet $(\mathrm{p}=0.0027)$. The lipophorin levels did not differ in bees fed with the fermented versus unfermented diet $(p=0.927)$. However, the vitellogenin levels were significantly higher in the bees fed the fermented diet. Survival rates were higher for bees fed beebread or either of the protein diets, compared with bees fed only sucrose $(\mathrm{p} \leq 0.001)$. There was no significant difference in survival for bees fed one of the protein diets compared to beebread $(p=0.188)$. The fermented diet was consumed at a significantly greater rate, compared to the unfermented diet $(\mathrm{p}=0.002)$. Preference for these diets followed the same trend $(\mathrm{p} \leq 0.001)$. In the field, the fermented diet was consumed at a greater rate $(\mathrm{p} \leq 0.001)$. However, when side by side comparisons were made in the same colony, the consumption did not differ $(\mathrm{p}=0.850)$. One of the colonies fed with the unfermented protein diet had a small, non-significant, increase in open and sealed brood areas $(p=0.100)$. A second colony fed with the same diet absconded after 15 days. One of the colonies fed with the fermented diet had a significant increase in open brood area. A second colony fed on the same diet grew considerably and had to be transferred to a larger hive. One of the control colonies had a strong reduction in sealed brood from day 45 to 60, ending up with about the same amount as at day 0 . The other control colony (no protein supplement) varied considerably in brood area and had about the same amount as at the beginning of the experiment. We conclude that fermented protein diets are more palatable, increase protein levels in the hemolymph and the amount of brood in the colonies. 


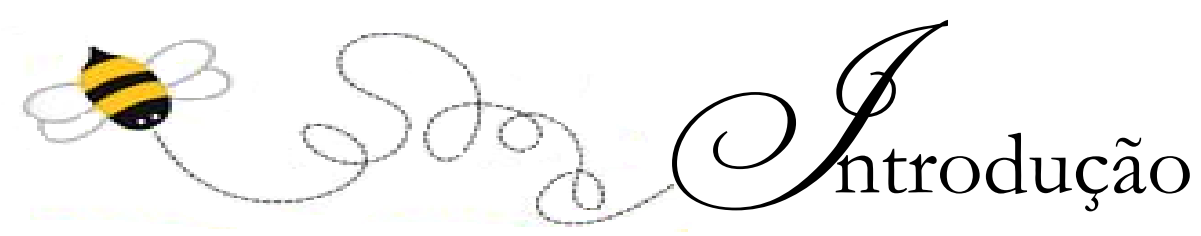




\section{Introdução}

As abelhas Apis mellifera são um dos poucos insetos cuja importância comercial é o cultivo, fazendo com que vários pesquisadores mantenham uma investigação intensa sobre quais são as necessidades nutricionais desses animais (Crailsheim, 1990). Por serem insetos de grande importância ecológica e econômica, tais estudos mostraram que a saúde das colônias das abelhas tem sido influenciada pela pouca disponibilidade de alimentos na natureza (Somerville, 2005). A capacidade produtiva e reprodutiva destes insetos está relacionada com a eficiência nutricional (Couto, 1998), e embora o fornecimento de alimento energético estimule a produção de cria, o pólen limita este crescimento e seu efeito nutricional afeta a capacidade da colônia em cuidar das crias mais novas (Cremonez, 2001).

As abelhas são consideradas muitas vezes como super-organismos (Seeley, 1985) e, portanto, a nutrição desses insetos deve ser investigada sob três níveis, sendo eles a nutrição colonial, a nutrição dos adultos (operária, zangão e rainha) e nutrição larval. Esta sequência nutricional apresenta uma crescente complexidade, pois os distúrbios nos estágios anteriores afetam as fases subsequentes, e vice-versa.

Estoques baixos de pólen na colônia podem impedir um bom desenvolvimento das larvas e dos adultos (Turcatto, 2011). Assim, a qualidade ou o número de adultos na próxima geração pode ser afetado, o que poderia influenciar a criação das gerações posteriores. Faltando alimento estocado na colônia, ou disponível na natureza, acarreta o início antecipado do forrageamento. Então, colônias que apresentam baixos estoques de alimento (proteína) armazenado nos favos, têm como consequência um declínio na quantidade de abelhas jovens presentes para as gerações seguintes e também um tempo de vida mais curto de suas operárias em geral (DeGrandi-Hoffman, et al., 2010). 
Em uma colônia, os níveis nutricionais estão intimamente ligados através de numerosas interações entre os indivíduos adultos, e ambas são altamente dependentes de estoques de produtos da colônia. Sendo assim, as abelhas adultas podem adaptar suas estratégias de forrageamento ou cuidados com as crias de acordo com as necessidades nutricionais da colônia (Crailsheim, 1991, 1998). Pensando sempre que, uma colônia saudável não é apenas uma colônia que consegue resistir a doenças, mas uma colônia que consegue gerar indivíduos bem nutridos, capazes de realizar suas tarefas e produzir descendentes saudáveis (Brodschneider e Crailsheim, 2010).

Como todos os animais, inclusive os insetos, as abelhas devem consumir certos nutrientes que são considerados essenciais em sua dieta (Keller et al., 2005). As necessidades nutricionais das abelhas $A$. mellifera, são atendidas pela coleta de pólen e néctar, onde o pólen satisfaz o requerimento de proteínas, minerais, lipídeos e vitaminas e o néctar satisfaz o requerimento de carboidratos (Herbert Jr., 1992). É sabido que para um máximo desenvolvimento, as abelhas necessitam de dez aminoácidos essenciais, como arginina, histidina, lisina, triptofano, fenilalamina, metiolina, treonina, leucina, isoleucina e valina (De Groot, 1953). Para obter tais aminoácidos, necessitam de reservas de alimento suficientes que sirvam para atender a sua própria alimentação e das crias em desenvolvimento.

Em condições normais, o néctar coletado nos nectários florais e depois transportado para a colônia e armazenado nos favos, fornece os carboidratos, os quais são convertidos em mel e utilizado como fonte de energia para suas funções vitais. As operárias adultas são fortemente dependentes das reservas de carboidratos na colônia e não sobrevivem a longos períodos sem esse tipo de substância em seu organismo, já que não possuem reservas em seus corpos, ao contrário das larvas jovens (Hrassnigg e Crailsheim, 2005).

O pólen é o plasma do germe masculino das plantas, e contêm normalmente, de 6 a $28 \%$ de proteína e é a única fonte de proteína disponível 
para as abelhas na natureza (Winston, 2003). Além de suprir as exigências de aminoácidos, essa substância também preenche as necessidades de lipídeos, variando de 1 a 20\% (normalmente menos de 5\%), vitaminas e minerais como sódio, potássio, cálcio, magnésio, cloro, fósforo, cobre, iodo, manganês, cobalto, zinco e níquel (que são indispensáveis para o desenvolvimento de sua estrutura corporal) (Herbert e Shimanuki, 1978) e os esteróis, que estão presentes em quantidades menores que $0,5 \%$, mas são essenciais (Winston, 2003).

As abelhas operárias executam diferentes tarefas durante o estágio adulto, de acordo com a idade e os requerimentos da colônia e, portanto, as exigências nutricionais de operárias, zangões e rainha diferem um pouco, de acordo com necessidades fisiológicas, assim como as funções que cada um desempenha dentro da colônia. Os materiais que as abelhas necessitam são coletados pelas operárias forrageiras de acordo com as necessidades da colônia e a disponibilidade no campo. A qualidade e a quantidade destes materiais coletados podem variar no decorrer do dia, e assim as forrageadoras podem alterar o tipo de coleta para atender às exigências da colmeia (Free, 1980). A diversidade do pólen também depende da diversificação da flora, do crescimento das plantas e das estações do ano ( $\mathrm{Li}$ et al., 2012). Dessa maneira, o requerimento anual desse pólen por uma colônia varia consideravelmente dependendo da localização e tamanho populacional da mesma. Muitos fatores como a temperatura do ar, o pH e a fertilidade do solo também afetam o valor nutritivo do pólen.

As diferenças na digestibilidade entre os tipos de pólen podem surgir pelas diferenças entre as porosidades de suas paredes, espessura e composição. Essas paredes resistem à deterioração e digestão, e embora o pólen seja rico em proteínas (Roulston e Cane, 2000) estas aparentemente não estão completamente disponíveis até terem sido processadas pelas bactérias no Beebread (pão de abelha) (Herbert e Shimanuki, 1978; Gillian, 1997). Este é produzido através da regurgitação de mel ou outras secreções glandulares, o qual ajuda na preservação contra microorganismos nocivos. Dessa maneira, há uma melhora na 
digestibilidade do pólen e no seu valor nutritivo (Herbert e Shimanuki, 1978). A conversão de pólen para Beebread e suas alterações bioquímicas é o resultado de uma ação microbiana, principalmente do ácido láctico e da fermentação provocada por bactérias e leveduras, reduzindo o pH (Foote, 1957; Haydak, 1958). A origem da planta a qual foi coletado tal pólen influencia o valor nutricional do mesmo (Gregory, 2006; De Jong et al., 2009).

O Beebread contém mais açúcares redutores do que o pólen, comparando em uma mesma espécie de planta (Gilliam, 1979). Este também é superior ao pólen coletado pelas abelhas quando comparado aos valores de proteína na hemolinfa dessas abelhas alimentadas com estes materiais (Cremonez et al., 1998).

A disponibilidade de proteína e, principalmente a concentração de proteína no pólen, é essencial para o crescimento da cria (Crailsheim, 1990; Crailsheim et al., 1992) e também desempenha um papel na longevidade, funcionamento e saúde dos indivíduos da colônia (Sagili e Pankiw, 2007).

Como as abelhas não armazenam grande quantidade de pólen na colônia, os estoques diminuem rápido em períodos de pouco forrageamento ou falta de recursos florais na natureza (Schmickl e Crailsheim, 2002). Dessa maneira, o enfraquecimento da colônia acarreta na diminuição da postura da rainha, que reduz consideravelmente a quantidade de indivíduos em diversos estágios de desenvolvimento (Huang, 2010) e pode comprometer o desenvolvimento normal e o crescimento da colônia (Somerville, 2005). Como a longevidade das operárias é afetada pelo começo do forrageio, as operárias que se tornam forrageiras mais cedo, morrem antes do que as operárias que executam tarefas dentro da colônia.

$\mathrm{Na}$ ausência de pólen e outros recursos alternativos, as abelhas recorrem à sua própria fonte de reserva, metabolizando tecido de seus corpos para prolongar suas vidas (Haydak, 1970). Há algumas plantas que possuem pólen altamente tóxico às abelhas. Dentre tais substâncias reconhecidas como tóxicas estão alguns açúcares, como a manose (Crane, 1977 e 1978), vários 
alcaloides (Detzel e Wink, 1993) e polifenólicos (Carisey e Bauce, 1997). Além da toxicidade do pólen, há os carboidratos que também são prejudiciais às abelhas, como a xilose, a galactose, a lactose, melibiose, manose, arabinose e rafinose (Barker e Lehner, 1974). Dessa maneira, além da escassez de alimento na natureza, os apicultores devem se preocupar com a disponibilidade da flora em torno do apiário.

Quando as condições ambientais estão extremamente desfavoráveis, a pouca quantidade de cria na colmeia pode sucumbir devido à fome, surgimento de doenças ou ser eliminada pelas operárias, que consomem parte dessa cria para saciar a falta de alimento (Turcatto, 2011). Sendo assim, a alimentação artificial é muito importante tanto para a manutenção da colônia como para o crescimento e multiplicação do número de colmeias (Herbert Jr., 1992). Herbert and Shimanuki (1978) definiram substituto de pólen como qualquer material que, quando fornecido às colônias de abelhas, supre as necessidades de pólen por um curto período de tempo. O suplemento de pólen, segundo a definição, deve conter proteínas, o que aumenta o valor nutritivo da dieta e age como um atrativo. Se não houver pólen ou um bom substituto do mesmo, o desenvolvimento das crias pode diminuir ou até cessar completamente (Haydak, 1963).

Além da carência nutricional em alguns meses do ano, doenças, ácaros, inseticidas, ou movimentação frequente no apiário, sem um manejo adequado, pode causar tensões nutricionais sobre as abelhas (Schmidt e Hanna, 2006). Portanto, há vários fatores que podem gerar um grande problema para a apicultura, em determinadas regiões, devido às monoculturas e ao clima local em algumas épocas do ano. Dessa maneira, a grande dificuldade é fazer a previsão das reais necessidades nutricionais das abelhas (Naug e Gibbs, 2009).

Sendo assim, a suplementação artificial neste período evita a ocorrência de uma série de fatores indesejáveis como o desenvolvimento inadequado das glândulas hipofaringeanas (as quais são responsáveis por secretarem a maior parte dos componentes da geleia real) e corpo gorduroso, 
redução da longevidade, desequilíbrio entre o número de nascimentos e mortes, redução da distância percorrida durante os voos e redução da resistência às doenças (Keller et al., 2005).

A alimentação artificial resulta em benefícios, pois assegura um desenvolvimento contínuo das colônias em lugares e épocas de escassez de néctar e pólen, além de prepará-los para aproveitar melhor o fluxo de néctar (Freitas e Echazarreta, 2001 in Sereia, 2009). As colônias que não tem acesso ao pólen apresentam uma capacidade reduzida no desenvolvimento da cria, declinando rapidamente a população, e eventualmente levando ao desaparecimento da colônia (Mattila e Otis, 2006). Portanto as larvas de abelhas (A.mellifera) são completamente dependentes das operárias adultas para se alimentar, visto que a geleia real é secretada em pequenas quantidades pelas glândulas hipofaringeanas e mandibulares das abelhas operárias jovens (Haydak, 1970). Para sua síntese, as abelhas exigem carboidratos, vitaminas, ácidos graxos, minerais e aminoácidos essenciais. Dessa forma, sua produção sempre tem sido realizada em épocas de abundância de recursos florais. Para assegurar sua produtividade e lucro em períodos de escassez é necessário a suplementação (Pereira et al., 2005), fornecendo aos ninhos tanto suplemento energético quanto proteico.

Para atender as exigências nutricionais das abelhas submetidas à produção de geleia real, vários tipos de suplementos têm sido elaborados. Entretanto, normalmente, os apicultores oferecem substitutos de pólen para as colônias sem os cuidados relativos à formulação da dieta, à deterioração durante o tempo de estocagem, à atratividade para as abelhas e aos custos dos componentes das dietas (Herbert Jr. et al., 1977). Dessa forma, esses suplementos nutricionais sofrem graves problemas, incluindo fraca atratividade e aceitabilidade pelas abelhas, e baixo valor nutricional (Schmidt e Hanna, 2006). Sendo assim, para que essas dietas artificiais sejam além de nutritivas, atrativas para essas abelhas, elas devem ser o mais parecido com o alimento natural, o Beebread. A avaliação de um suplemento pode ser realizada por uma variedade 
de medidas e observações realizadas como a produção total de mel, produção diária de cria, produtividade e longevidade individual das abelhas operárias adultas (Winston et al., 1983).

De um modo geral, um bom suplemento deve ser coletado e depois de ingerido deve disponibilizar os elementos nutricionais essenciais para o crescimento, desenvolvimento das colônias, longevidade e boa capacidade produtiva (Herbert e Shimanuki, 1978; Winston et al., 1983). Poucos estudos foram encontrados a respeito da longevidade das abelhas melíferas relacionados ao consumo de diferentes espécies de pólen (com diferentes proteínas e lipídeos) (Manning et al., 2007). Schmidt et al., 1989 (in Manning et al., 2007) encontraram que a longevidade de abelhas alimentadas com pólen de plantas polinizadas pelo vento foi menor que aquelas alimentadas com dietas a base de açúcar somente (sem proteína), talvez indicando a ausência de pólen atrativo ou componentes tóxicos.

Assim, apesar da diversidade da flora apícola no país, devido ao seu tamanho encontramos diversas realidades nutricionais. Como exemplo, no Nordeste brasileiro, durante a estação seca, ocorre uma escassez de pasto apícola e, consequentemente, de alimento para as abelhas (Pereira et al., 2005). Por conseguinte, todo ano os apicultores perdem uma grande parte das suas colônias, que abandonam os apiários em busca de novos pastos no período de escassez de alimento (Freitas, 1991; Lima, 1995). Dessa forma, a falta de recursos para adquirir o alimento e o desconhecimento de produtos que possam ser oferecidos às abelhas são os motivos que impedem a alimentação adequada das colônias no período necessário.

O uso de dietas artificiais pode resolver parcialmente esse problema. Contudo, apesar de várias pesquisas terem sido realizadas visando encontrar um substituto alimentar para as abelhas (Abbas et al., 1995; Cremonez, 1996, 2001; Azevedo-Benitez e Nogueira-Couto, 1998; Ellis e Hayes, 2009), não existem produtos eficazes de fácil acesso e baixo custo ao produtor. Dessa forma, a necessidade do apicultor de dispor de um alimento proteico para ser usado em 
qualquer época do ano e que seja coletado em quantidade pelas abelhas faz com que ele busque novas alternativas na expectativa de encontrar uma solução para esse problema. Um grande entrave no qual os pesquisadores se deparam quando utilizam suplementos proteicos para suprir a falta de recursos alimentares no campo, é o fator atratividade. Dessa maneira, a utilização de rações fermentadas poderia resolver tal problema, pois uma vez fermentado, a palatabilidade das dietas é melhorada e possivelmente o valor nutricional das rações é aumentado.

Assim, a suplementação com rações proteicas fermentadas na entressafra é uma ferramenta que os apicultores devem utilizar para aumentar suas produções, visto que, ao entrar no período de floração, as colônias estarão com a população de abelhas em um nível produtivo, não necessitando de um período maior de recuperação dos enxames (Pereira et al., 2005). 


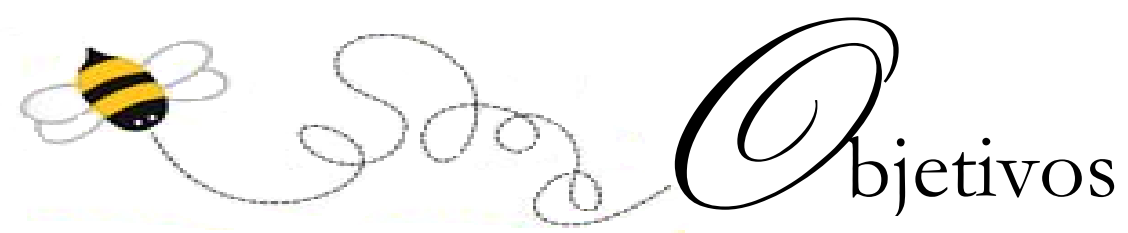




\section{Objetivos}

Atualmente, o maior problema para os apicultores é a perda de enxames por falta de alimento disponível na natureza em algumas épocas do ano, devido aos diferentes climas de algumas regiões do país, às monoculturas e a coleta de polens tóxicos de algumas plantas. Portanto, é necessário que os apicultores utilizem dietas artificiais que possam substituir o pólen, e assim atender as necessidades nutricionais das abelhas nesses períodos de escassez. Porém muitas dietas já utilizadas por apicultores, apesar de preparadas com ingredientes ricos nutricionalmente, muitas vezes não são consumidas pelas abelhas, provavelmente porque não são palatáveis. O pólen antes de ser consumido pelas abelhas é fermentado, portanto a elaboração de uma dieta que também seja fermentada poderia ser mais atrativa e mais palatável para as abelhas. Assim poderemos auxiliar os apicultores, que poderão manter suas colônias saudáveis nesses períodos, diminuindo as perdas. Dessa forma o presente trabalho teve como objetivos principais:

Testes no laboratório:

Desenvolvimento e testes de uma dieta artificial proteica utilizada como suplemento alimentar para colônias de abelhas;

Utilização do "Beebread" para a fermentação de uma dieta artificial proteica;

Verificação da palatabilidade da dieta artificial proteica fermentada;

Dosagem da quantidade de proteínas na hemolinfa de abelhas operárias recém- nascidas mantidas em estufas e alimentadas com diferentes dietas: fermentada e não fermentada durante sete dias; 
Avaliação do perfil de proteínas na hemolinfa, através da análise densitométrica das bandas de gel SDS-PAGE;

Verificação da taxa de sobrevivência das operárias colocadas em gaiolas e alimentadas com as diferentes dietas (fermentada e não fermentada), até a última abelha sobrevivente;

Verificação das taxas de consumo e preferência de cada dieta, a fim de definir qual dieta é a mais consumida e a mais palatável para as abelhas;

Testes no campo:

Testes com as dietas pré-selecionadas no laboratório em colônias nas épocas de escassez (no período de Maio a Julho), no Apiário experimental da Faculdade de Medicina de Ribeirão Preto/USP);

Avaliação da utilização das dietas como suplemento alimentar por meio de métodos como: análise da área de cria através de mapeamentos realizados quinzenalmente, pesagem diária através de balanças digitais, taxa de consumo e preferência dessas dietas. 



\section{Material e Métodos}

\subsection{Local de estudo e escolha do material}

Os experimentos foram realizados no Apiário Experimental do Departamento de Genética da Faculdade de Medicina de Ribeirão Preto - USP (Figura 1), localizado na região Noroeste do Estado de São Paulo, numa altitude de $621 \mathrm{~m}$, a $21^{\circ} 11^{\prime}$ latitude sul e $47^{\circ} 43^{\prime}$ de longitude oeste, com clima tropical úmido (com inverno seco e verão chuvoso) (Gonçalves, 1978). Foram utilizadas abelhas Africanizadas Apis mellifera instaladas em colmeias padronizadas modelo Langstroth.

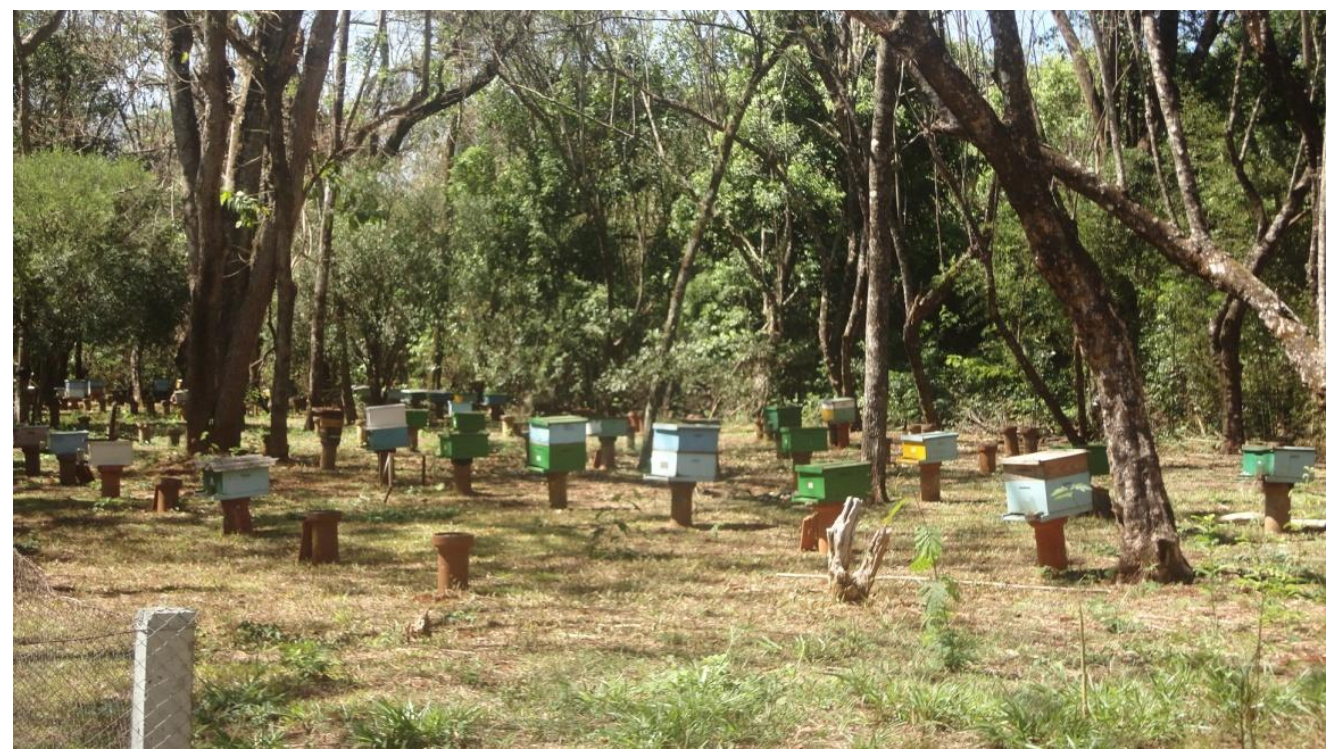

Figura 1: Apiário experimental do Departamento de Genética da Faculdade de Medicina de Ribeirão Preto - USP. (Foto: Joyce M. V. Almeida)

3.2 Utilização de diferentes métodos para determinar a eficiência das dietas proteicas artificiais em abelhas africanizadas mantidas em laboratório

3.2.1 Desenvolvimento do inoculo e condições de fermentação 
Inicialmente, foi utilizado iogurtes a base de soja, com vários tipos de microrganismos para realizar o processo de fermentação como descrito por Ellis et al, 2009. Porém, não houve sucesso nesse tipo de fermentação. Após realizarmos testes misturando "Beebread" e xarope, ocorreu uma grande incidência de fungos, inviabilizando todo o processo. Outra dificuldade encontrada na fermentação da dieta foi que muitas vezes esse processo não ocorria devido a diferentes concentrações de "Beebread" e de xarope adicionadas. Após várias tentativas, como mudança nas quantidades de "Beebread" e xarope, alteração na temperatura da estufa, além de várias tentativas na forma de armazenamento dessa mistura, chegouse a uma formulação satisfatória, não apresentando a proliferação de fungos.

Para a fabricação de um inoculo fermentado, todos os materiais utilizados, inclusive a estufa, foram totalmente esterilizados com álcool 70\%. Foi coletado "Beebread", diretamente dos favos das colônias utilizadas para o experimento, com uma espátula coletora esterilizada. Logo após, o "Beebread" foi armazenado em uma placa de petri totalmente esterilizada (Figura 2). Para cada 10 gramas de Beebread coletado foram adicionados $300 \mathrm{~mL}$ de xarope de sacarose a $50 \%$, o qual é constituído de 50\% de água e 50\% de açúcar (v/v).

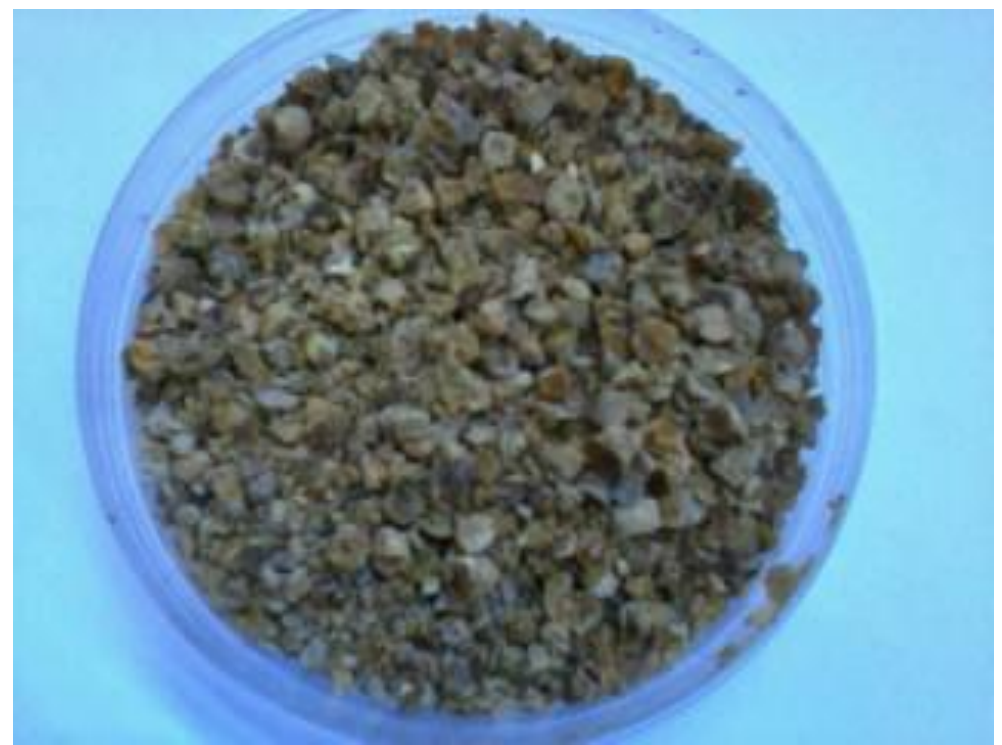

Figura 2: Placa de petri esterilizada contendo "Beebread" retirado dos favos. (Foto: Joyce M. V. Almeida) 
Esta mistura foi homogeneizada e armazenada em frascos do tipo reagente de vidro borosilicato incolor (Figura 3), totalmente esterilizados e colocados em estufa a $35^{\circ} \mathrm{C}$, com umidade controlada (70\%). Esses frascos não foram vedados totalmente, para que houvesse a livre entrada de ar. Em um intervalo de dois dias, os frascos foram abertos para uma nova homogeneização.

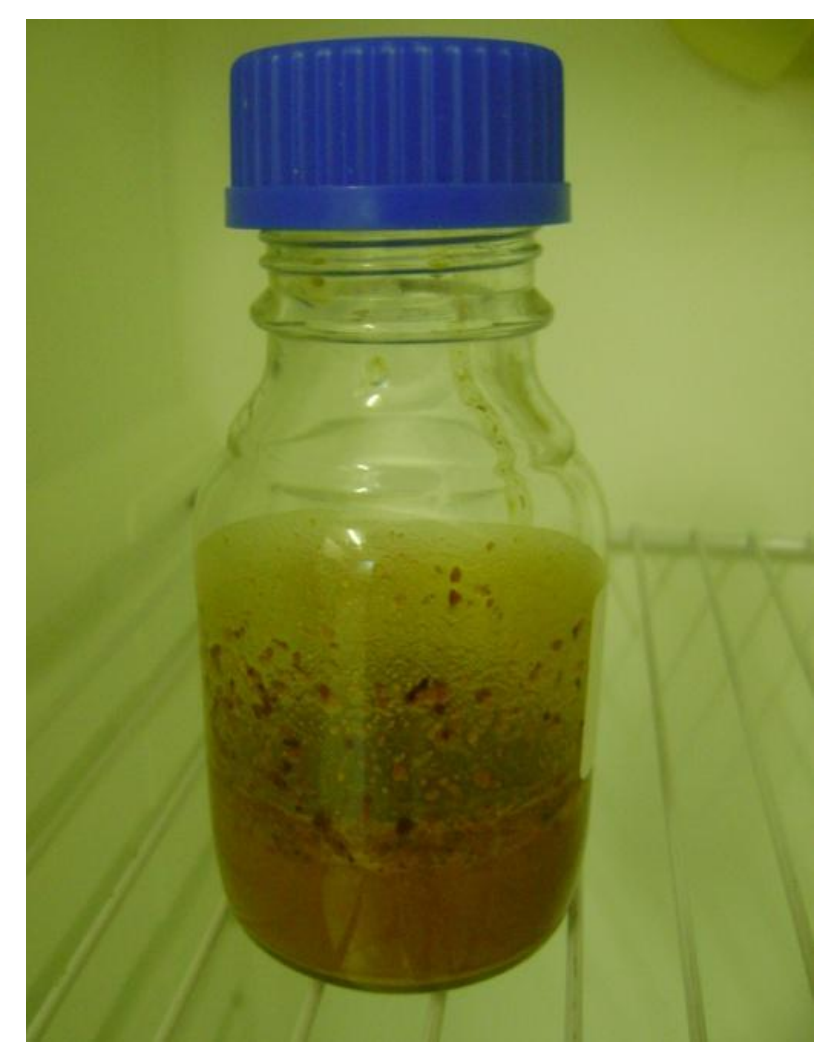

Figura 3: Frasco reagente em vidro borosilicato incolor com a mistura de Beebread e xarope de sacarose 50\% (v/v). (Foto: Joyce M. V. Almeida)

Após 28 dias, a mistura já estava totalmente fermentada, apresentando-se com um aspecto líquido, com o surgimento de várias bolhas na superfície (Figura 4), indicando a saída do gás carbônico. Além disso, a mistura apresentou ainda cheiro de ácido acético, o que veio a confirmar um processo de fermentação. Após esta confirmação, os frascos foram totalmente vedados para evitar contaminação. 


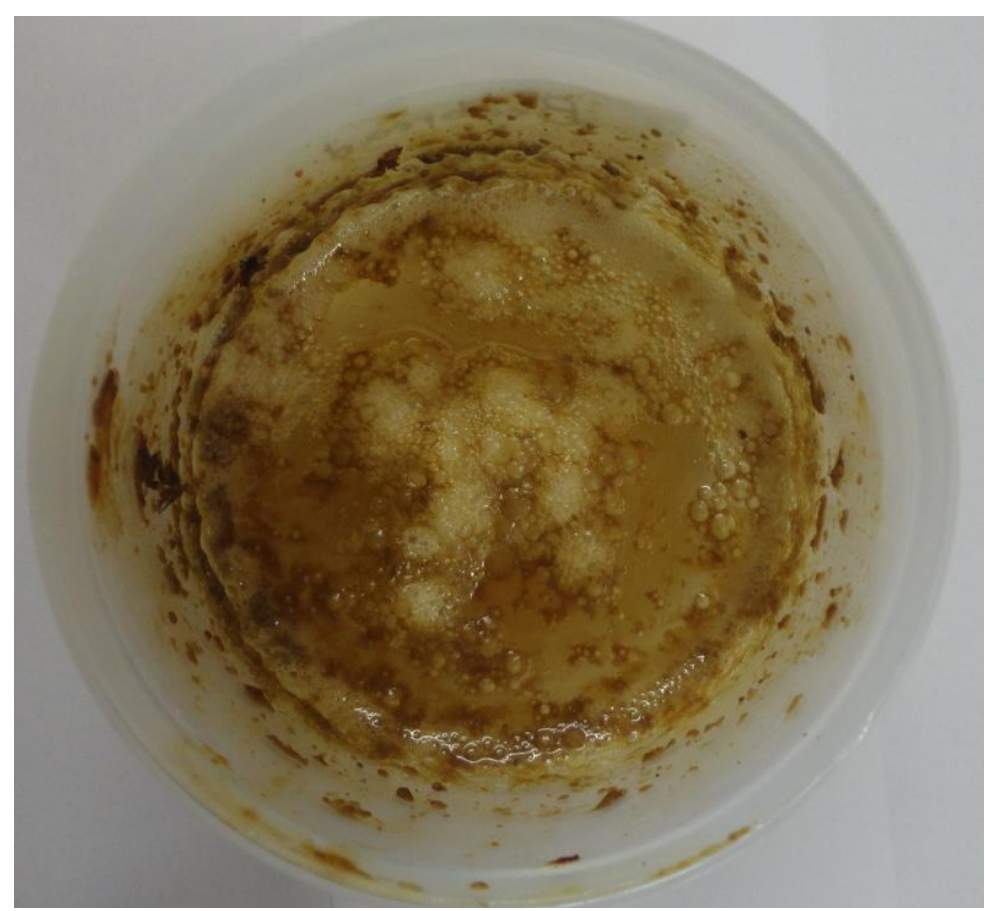

Figura 4: Isca fermentada (10 gramas de "Beebread" com 300 $\mathrm{mL}$ de xarope de sacarose) após 28 dias na estufa, com aspecto líquido e formação de bolhas. (Foto: Joyce M. V. Almeida)

\subsubsection{Procedimento Experimental}

Para os experimentos, foram utilizados quatro ninhos modelo Langstroth, localizados no apiário experimental. Inicialmente, foram retirados quadros de crias de operárias operculadas pré-emergentes (da mesma colônia) e colocados em gaiolas de madeira cobertas por telas de nylon e introduzidas em uma estufa com temperatura e umidade controladas, em torno de $34^{\circ} \mathrm{C}$ e $80 \%$, respectivamente, onde ocorreu a emergência dessas operárias. Após a emergência de tais abelhas (dentro de um período de 12 - 16 horas), amostras de 100 abelhas recém-emergidas foram coletadas e introduzidas em gaiolas plásticas de confinamento $(21,5 \mathrm{~cm} \times 13 \mathrm{~cm} \times 13 \mathrm{~cm}$ ), com dois furos (um frontal e outro superior) e uma tela na parte frontal para a ventilação no interior da gaiola (Figura 
5), onde foram alimentadas com diferentes dietas (tanto dietas frescas quanto fermentadas) durante sete dias, sendo esse procedimento repetido por oito vezes.

As gaiolas com as abelhas foram mantidas em estufa, sem nenhuma luz, sob as mesmas condições de temperatura e umidade mencionadas acima. As dietas oferecidas continham $25 \%$ de Proteína Bruta e variaram em relação à presença ou ausência de fermentação (isca fermentada). Xarope 70\% foi dado livremente para todos os grupos de abelhas.

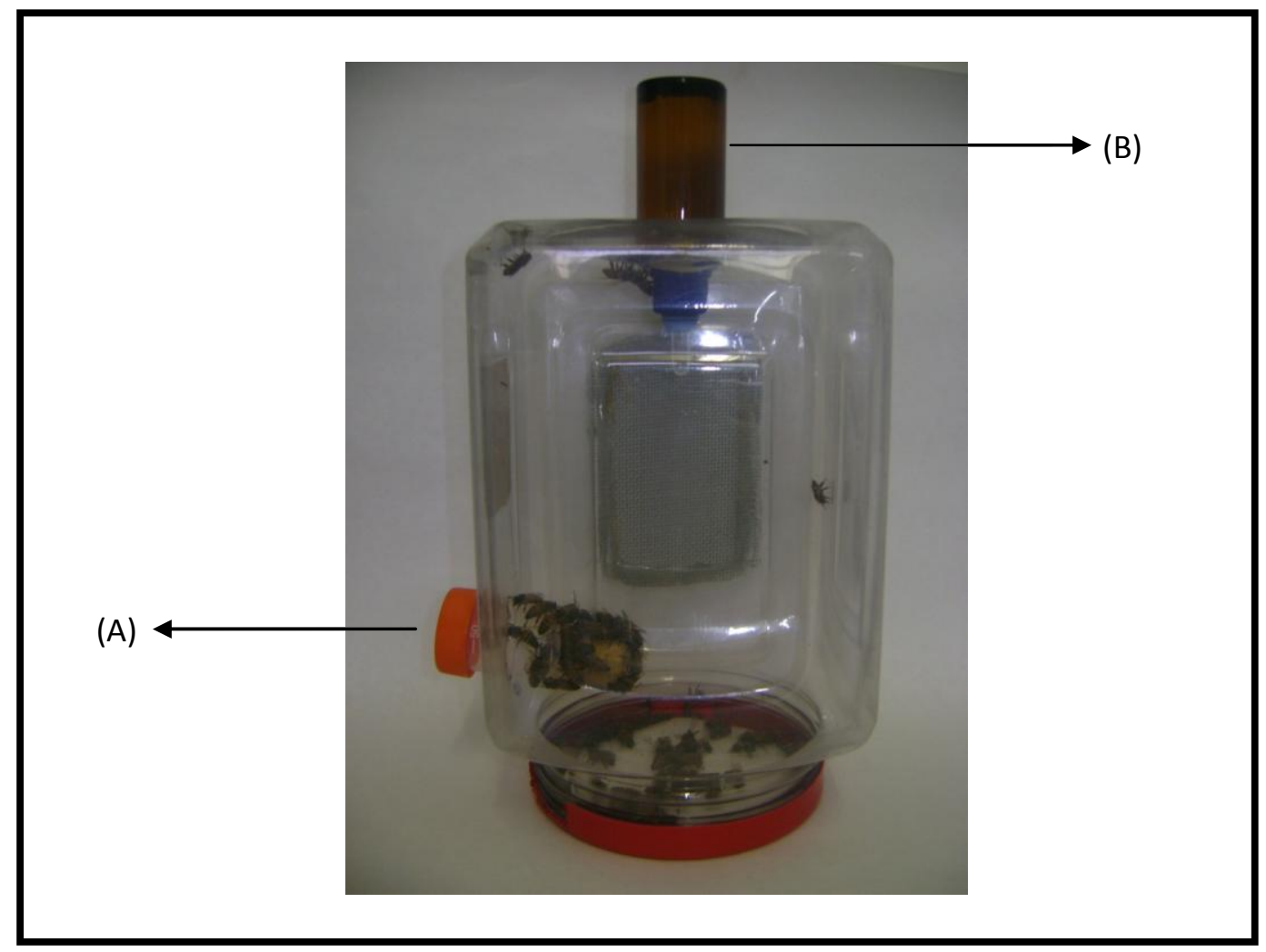

Figura 5: Gaiola plástica de confinamento contendo 100 operárias recém-emergidas. (A) recipiente plástico com abertura frontal contendo o alimento proteico; (B) Recipiente contendo xarope 70\%. (Foto: Joyce M. V. Almeida)

Para estes experimentos foram utilizadas diferentes dietas, quais sejam: D1 - constituída de Beebread (pólen) coletado dos próprios favos e misturado com água até ter uma consistência de pasta, (utilizada como controle positivo); D2 constituída de xarope (açúcar em água 70\%) (utilizada como controle negativo); D3 
- constituída de levedura de cana, farinha de soja, farelo de arroz e açúcar; e D4 com a mesma formulação da dieta D3, porém adicionando o inoculo fermentado, deixando 28 dias na estufa para que ocorresse a fermentação (Tabela 1).

Tabela 1: Dietas energético-proteicas elaboradas e fornecidas às operárias de abelhas africanizadas Apis mellifera.

\begin{tabular}{|c|c|}
\hline Dietas & Ingredientes \\
\hline \hline \multirow{3}{*}{ D1 (controle positivo) } & $\begin{array}{c}5 \mathrm{~g} \text { de "Beebread" }+4 \mathrm{~mL} \text { de } \\
\text { água }\end{array}$ \\
& $\begin{array}{c}\text { Xarope de sacarose } 70 \% \\
\text { (v/v) }\end{array}$ \\
& $20 \mathrm{~g}$ de levedura de cana \\
& $16,7 \mathrm{~g}$ de farinha de soja \\
& $43,3 \mathrm{~g}$ de farelo de arroz \\
& $20 \mathrm{~g}$ de Açúcar \\
& Xarope de sacarose $70 \%$ \\
& (v/v) até dar consistência \\
& pastosa \\
& $20 \mathrm{~g}$ de levedura de cana \\
& $16,7 \mathrm{~g}$ de farinha de soja \\
& $43,3 \mathrm{~g}$ de farelo de arroz \\
& $20 \mathrm{~g}$ de Açúcar \\
& $40 \mathrm{~mL}$ da isca fermentada \\
Darope de sacarose $70 \%$ \\
& (v/v) até dar consistência \\
& pastosa \\
\hline
\end{tabular}

Para a determinação da quantidade de ingredientes em cada dieta e a porcentagem de proteína bruta total em cada uma delas, foram realizados cálculos baseados no Quadrado de Pearson, ou quadrado de misturas, que serve para determinar as percentagens em que cada um dos ingredientes deve ser misturado, de forma a se obter uma mistura com determinadas características.

Quatro gramas das dietas D1, D3 e D4 foram introduzidas a cada dois dias nas gaiolas plásticas de confinamento, através de um recipiente plástico com abertura basal (Figura 6). Ao final de cada experimento, as sobras das dietas foram pesadas em balança de precisão, para obter o consumo total de cada uma delas. 


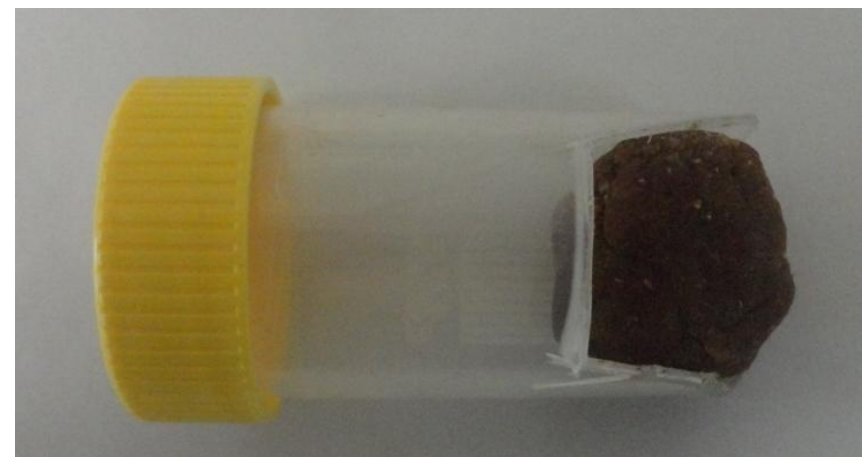

Figura 6: Recipiente plástico (tubo falcon $50 \mathrm{~mL}$ cortado na metade) utilizado para introduzir as dietas nas gaiolas plásticas de confinamento, para alimentar as abelhas confinadas. (Foto: Joyce M. V. Almeida).

\subsubsection{Determinação da concentração de proteína total na}

\section{hemolinfa de operárias confinadas em gaiola}

Antes do confinamento nas gaiolas plásticas (dia zero), $10 \mu \mathrm{L}$ de hemolinfa de amostras de 20 operárias recém-emergidas (12 - 16 horas de emergência) foi coletada para a quantificação de proteína ali existente. Após o confinamento e a alimentação das operárias com as respectivas dietas, foi realizado o mesmo procedimento, isto é, coleta de hemolinfa de uma amostra de 20 abelhas operárias de cada dieta após sete dias de alimentação.

As operárias foram anestesiadas sobre o gelo durante 10 minutos, antes da coleta de hemolinfa. $3 \mu \mathrm{L}$ de hemolinfa foi coletado com o auxílio de pipeta de volume 0,5 a $10 \mu \mathrm{L}$ em um através de um corte na base da asa (figura 7) e transferida juntamente com PTC (Feniltiocarbamida) e Inibidor de Protease (10\%) para tubos eppendorf de $0,6 \mathrm{~mL}$. 


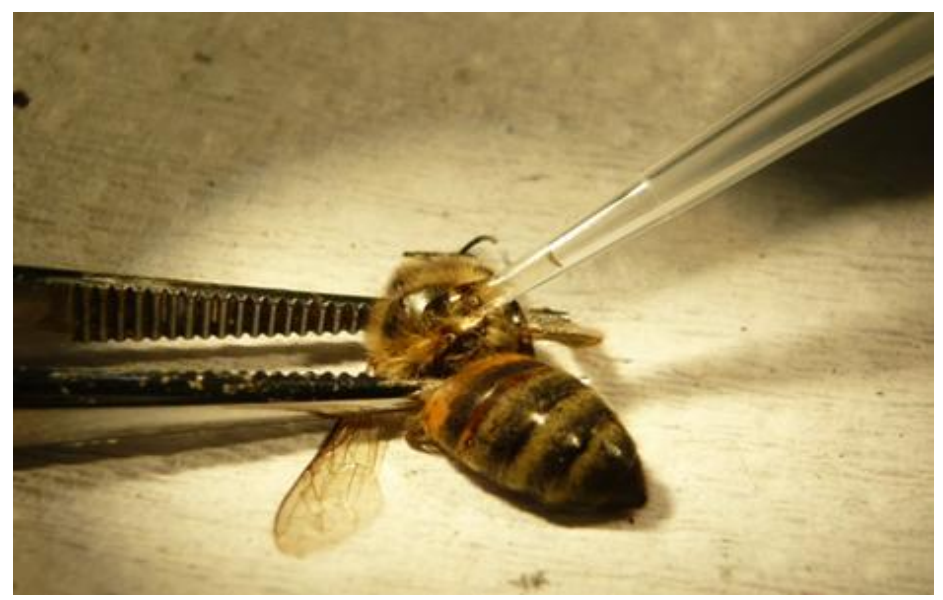

Figura 7: Hemolinfa de operária sendo coletada com a ajuda de uma micropipeta. (Foto: Aline P. Turcatto e Michelle M. Morais).

Estas amostras de hemolinfa foram centrifugadas a $4000 \mathrm{rpm}$ por 4 minutos à $4^{\circ} \mathrm{C}$ e o sobrenadante foi retirado e congelado à $-20^{\circ} \mathrm{C}$. A quantidade total de proteínas foi avaliada pelo método de Bradford, 1976 e a construção da curva padrão foi realizada utilizando albumina sérica bovina (BSA) (Turcatto, 2011).

Após a diluição das amostras $(2 \mu \mathrm{L}$ de água Milli-Q para $1 \mu \mathrm{L}$ de hemolinfa), adicionou-se em cada amostra $1 \mathrm{~mL}$ de reagente de Bradford em um eppendorf de 0,6 mL, logo após homogeneizado, foi aplicado em uma placa de Elisa, $200 \mu \mathrm{L}$ de cada amostra em triplicata. (Figura 8).

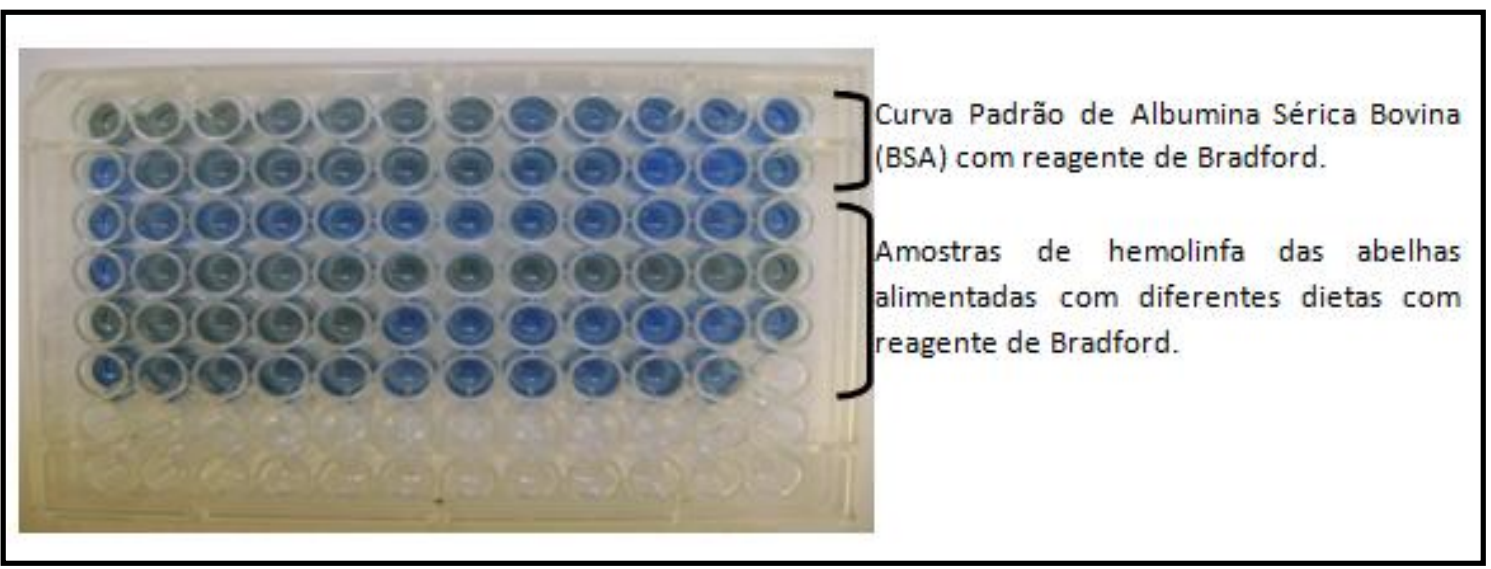

Figura 8: Placa de Elisa com curva padrão de albumina (BSA) e amostras com reagente de Bradford. 
A quantificação das amostras foi realizada por leitura em um comprimento de onda de $595 \mathrm{~nm}$ em espectrofotômetro Beckman® Coulter DXT880-multimode detector (Figura 9).

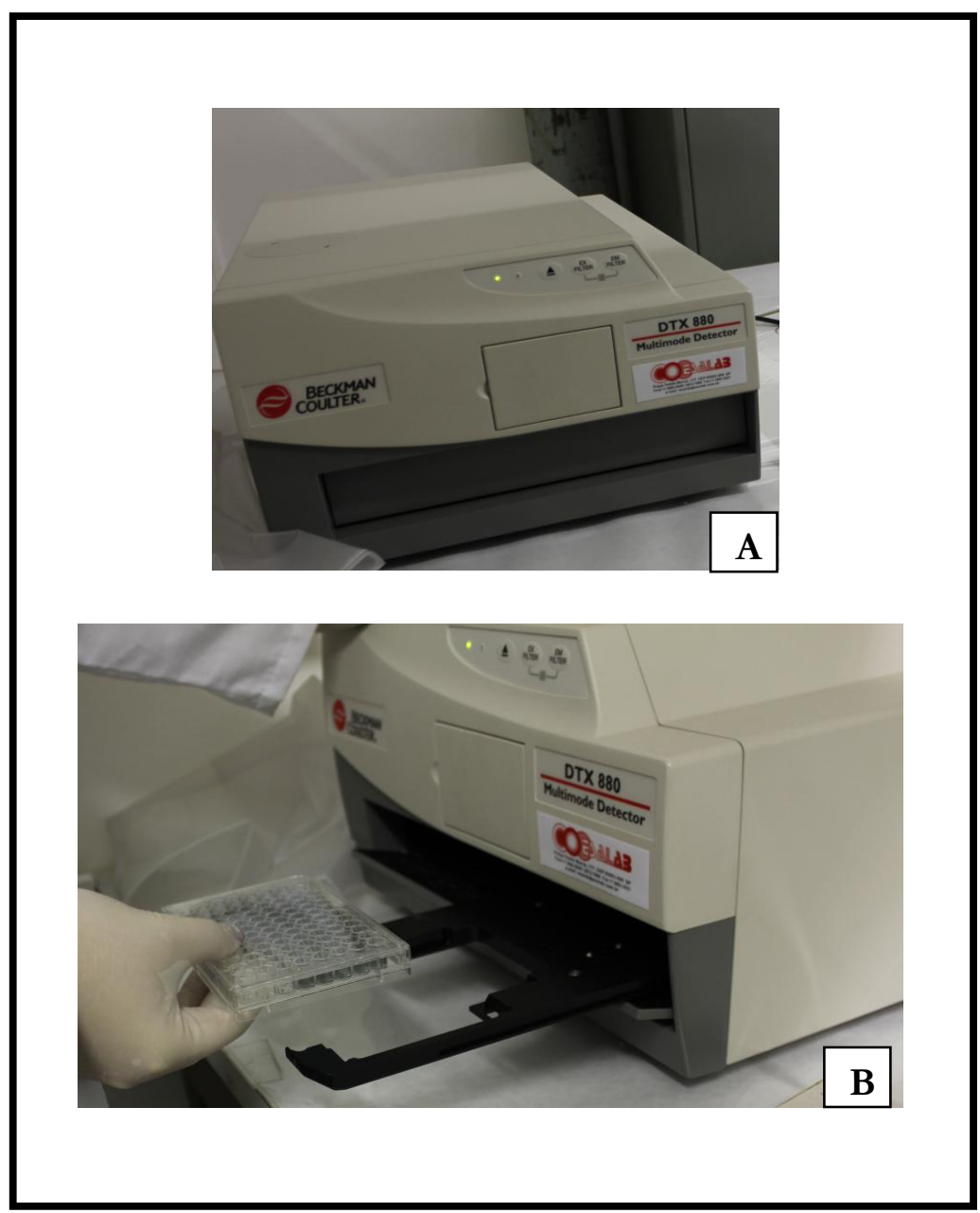

Figura 9: A - Espectrofotômetro utilizado para a leitura da quantificação proteica; B - Placa de Elisa sendo colocada no espectrofotômetro para a leitura. (Foto: Daniel Nicodemo)

\subsubsection{Padrão eletroforético para proteínas totais}

Para a análise qualitativa do perfil das proteínas da hemolinfa, utilizou-se $1 \mu \mathrm{l}$ de hemolinfa (que denominaremos como gel com amostras com volume fixo) dissolvida em tampão da amostra, Tris- $\mathrm{HCl}$ 0,25 M, pH 6,8, contendo 70\% de sacarose, 0,25\% SDS, 0,1\% bromofenol azul e 5\% B-mercaptoetanol. As amostras 
foram submetidas à desnaturação térmica $\left(100^{\circ} \mathrm{C}\right.$ durante 5 minutos) e após resfriamento, aplicadas em géis de separação $(100$ x 120 x 0,9 mm), com concentração de poliacrilamida de 7,5\%.

A migração das proteínas foi feita até que as amostras atingissem o final do gel, sob temperatura de $4^{\circ} \mathrm{C}$, corrente constante de $18 \mathrm{~mA}$ e utilizando tampão Tris-glicina - SDS no compartimento dos eletrodos. Após a separação por eletroforese, o gel foi corado com Coomassie Brillant Blue R-250, em etanol, água e ácido acético $(5: 5: 1 \mathrm{v} / \mathrm{v})$ para visualização das proteínas.

As proteínas Miosina, B-Galactosidase, Fosforilase-B, Albumina sérica bovina, Ovoalbumina e Anidrase carbônica com 205, 116, 97, 66, 45 e 29kDa, respectivamente, foram utilizadas como marcadores de massa molecular. Imagens dos géis SDS-PAGE foram capturadas e os perfis individuais de cada amostra foram analisados por densitometria com o auxílio do Software Adobe Photoshop CS5.

\subsubsection{Avaliação da taxa de sobrevivência de abelhas operárias adultas confinadas em laboratório}

Para este experimento, avaliamos a taxa de sobrevivência de operárias confinadas em gaiolas plásticas e alimentadas com as diferentes dietas. Foram utilizadas doze gaiolas de confinamento, contendo 100 abelhas recém-emergidas de uma mesma colônia, sendo que três destas gaiolas foram alimentadas com a dieta D1 (controle positivo), três alimentadas com a dieta D2 (controle negativo), três alimentadas com a dieta D3 e as últimas três alimentadas com a dieta D4 conforme especificadas na Tabela 1.

As gaiolas foram mantidas em estufa com temperatura por volta de $35^{\circ} \mathrm{C}$ e umidade controlada (80\%). A partir do primeiro dia de experimento, todos os dias no mesmo horário, foram contadas as abelhas mortas dentro de cada gaiola até a 
última abelha sobrevivente. Os dados obtidos eram anotados para a análise posterior.

\subsubsection{Determinação da taxa de consumo e preferência de cada dieta no laboratório}

Para esta etapa do experimento, foram analisadas a taxa de consumo e a preferência de cada dieta. Foram utilizadas 10 gaiolas de confinamento, contendo 100 abelhas recém-emergidas de uma mesma colônia. Em cada gaiola, foram fornecidos $4 \mathrm{~g}$ da dieta $\mathrm{D} 3$ de um lado e $4 \mathrm{~g}$ da dieta $\mathrm{D} 4$ do outro lado, ao mesmo tempo, para que essas abelhas pudessem ter a opção de escolher qual dieta consumir.

As gaiolas foram mantidas em estufa com temperatura e umidade controlada, $35^{\circ} \mathrm{C}$ e $80 \%$ respectivamente. O experimento teve duração de 5 dias, as dietas eram pesadas no segundo e no quarto dia de experimentos em balança de verificação de peso, para verificar a taxa de consumo de cada uma.

\subsection{Determinação da eficiência de dietas proteicas em colônias de abelhas africanizadas}

Logo após os testes serem realizados em laboratório para avaliar a eficiência da fermentação induzida na dieta, através das análises realizadas na hemolinfa das abelhas alimentadas com essa dieta e verificarmos a aceitabilidade pelas operárias tratadas em laboratório, testamos tais dietas em campo para comprovarmos se havia melhoras nas colônias em épocas de pouca oferta de alimento na natureza. 
Para estes experimentos, foram selecionados 6 núcleos de modelo Langstroth, todos padronizados, sendo 3 quadros de cria e dois de alimento (Figura 10). Dois destes núcleos foram definidos como grupo controle (aqueles que não receberam nenhum tipo de alimentação suplementar); dois receberam a dieta D3 e dois receberam a dieta D4 (fermentada). Durante os 60 dias de experimento, a cada sete dias eram fornecidas $100 \mathrm{~g}$ de cada dieta às colônias selecionadas.

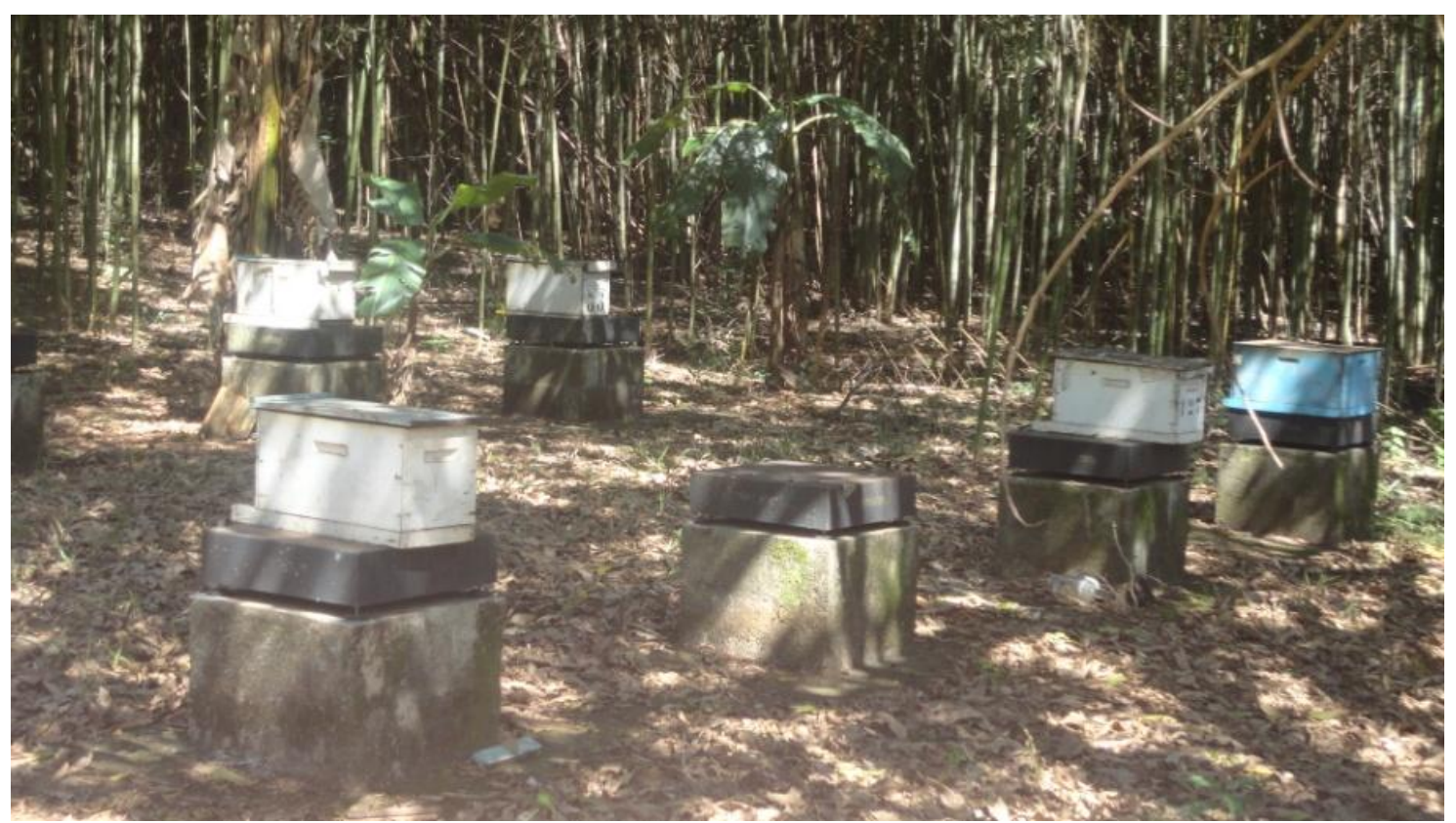

Figura 10: Núcleos padronizados dispostos em balanças digitais. (Foto: Joyce M. V. Almeida)

\subsubsection{Monitoramento dos pesos das colônias}

Todos os núcleos utilizados neste experimento foram instalados sobre Balanças Eletrônicas de Bancada, Toledo, modelo 2090, Terminal de Pesagem modelo 9091WEB e o software EASYLINK (Figura 11) nas quais os pesos dessas colônias eram controlados todos os dias. 


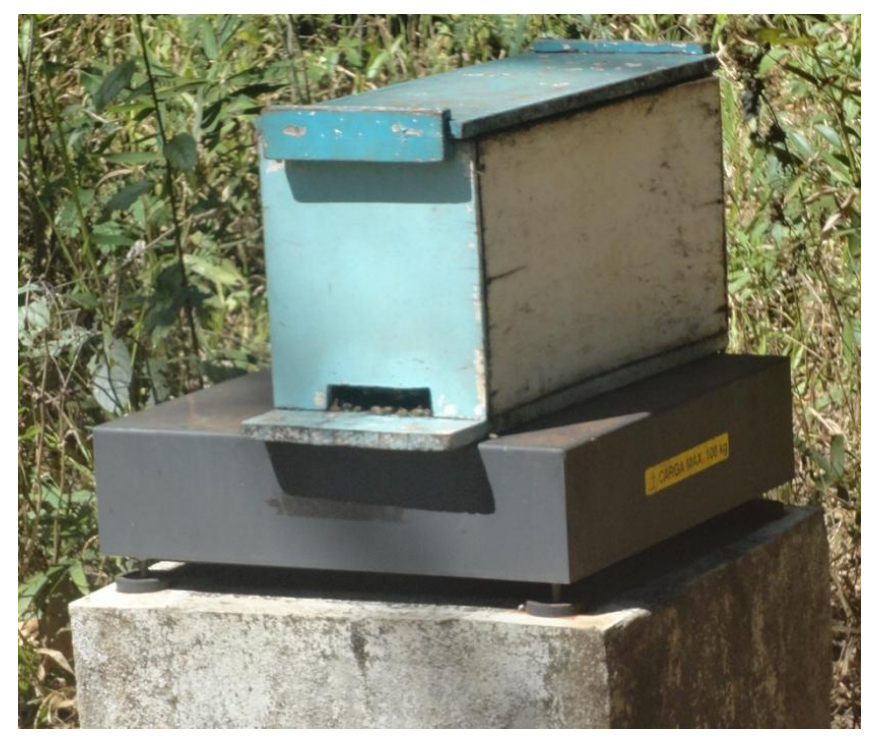

Figura 11: Núcleo disposto sobre balança digital dotada de sensores. (Foto: Joyce M. V. Almeida)

Os dados foram monitorados automaticamente e foram registrados em um computador, sendo estes, dispostos para a análise (Figura 12).

O peso diário de cada núcleo foi anotado para verificação posterior da eficiência da dieta fermentada sobre o crescimento colonial. Cada um dos núcleos foi alimentado durante 60 dias para avaliação. Semanalmente, foi introduzido $100 \mathrm{~g}$ de alimento (dietas D3 e D4), e a sobra foi pesada para posterior análise de aceitabilidade das dietas. 


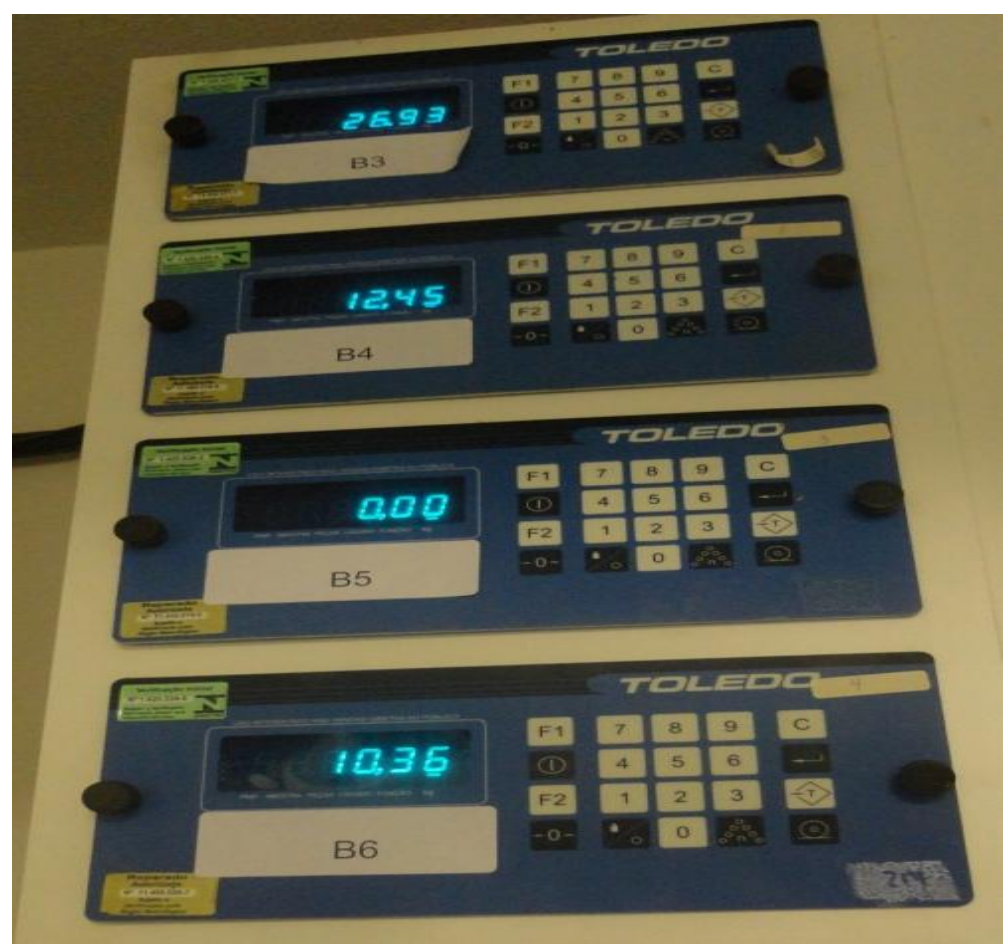

Figura 12: Painéis eletrônicos dispostos na parte interna do laboratório, indicando os pesos das balanças que se encontram localizadas no apiário. (Foto: Joyce M. V. Almeida)

\subsubsection{Mapeamento da área de cria}

A análise dos resultados para estas dietas foi obtida através do mapeamento da área de cria conforme metodologia adaptada de Al-Tikrity et al. (1971). Os mapas foram feitos antes de iniciarmos o fornecimento das dietas e após, 15, 30, 45 e 60 dias, no período de escassez alimentar na região de Ribeirão Preto (de Maio a Julho). Os quadros com alimento e cria de cada núcleo foram medidos um a um, quanto a sua área de pólen, de néctar operculado, néctar aberto, cria operculada, cria aberta e área de favo vazia (Figura 13 A e B), através de um suporte de madeira com laterais construídas de arame esticado (Figura 14), formando quadrados de $5 \mathrm{~cm}$ de lado $\left(25 \mathrm{~cm}^{2}\right.$ de área ou 12 células de operárias). 


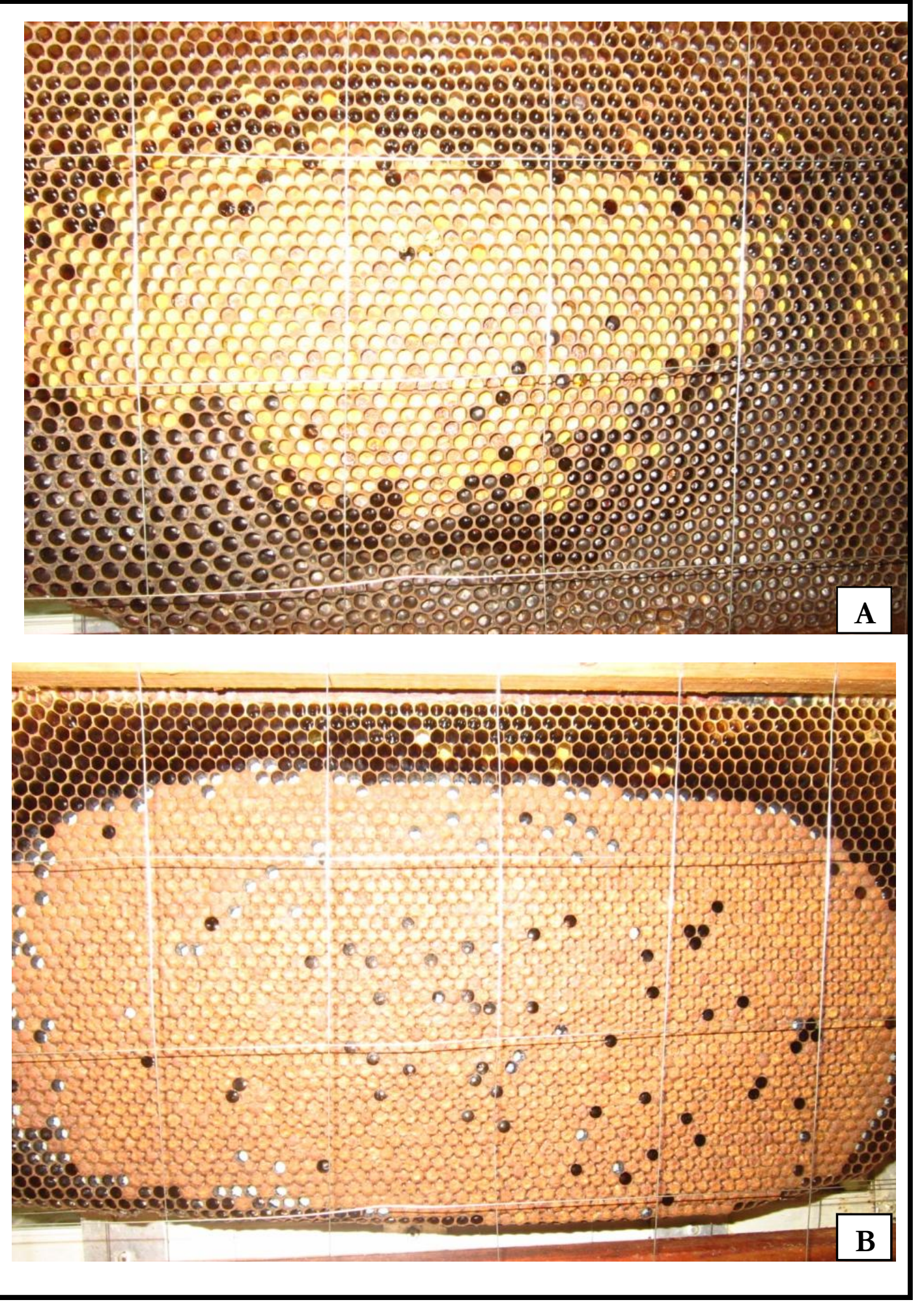

Figura 13: A - Quadro de alimento (pólen e néctar) sendo mapeado; B - Quadro de cria sendo mapeado. (Foto: Joyce M. V. Almeida) 


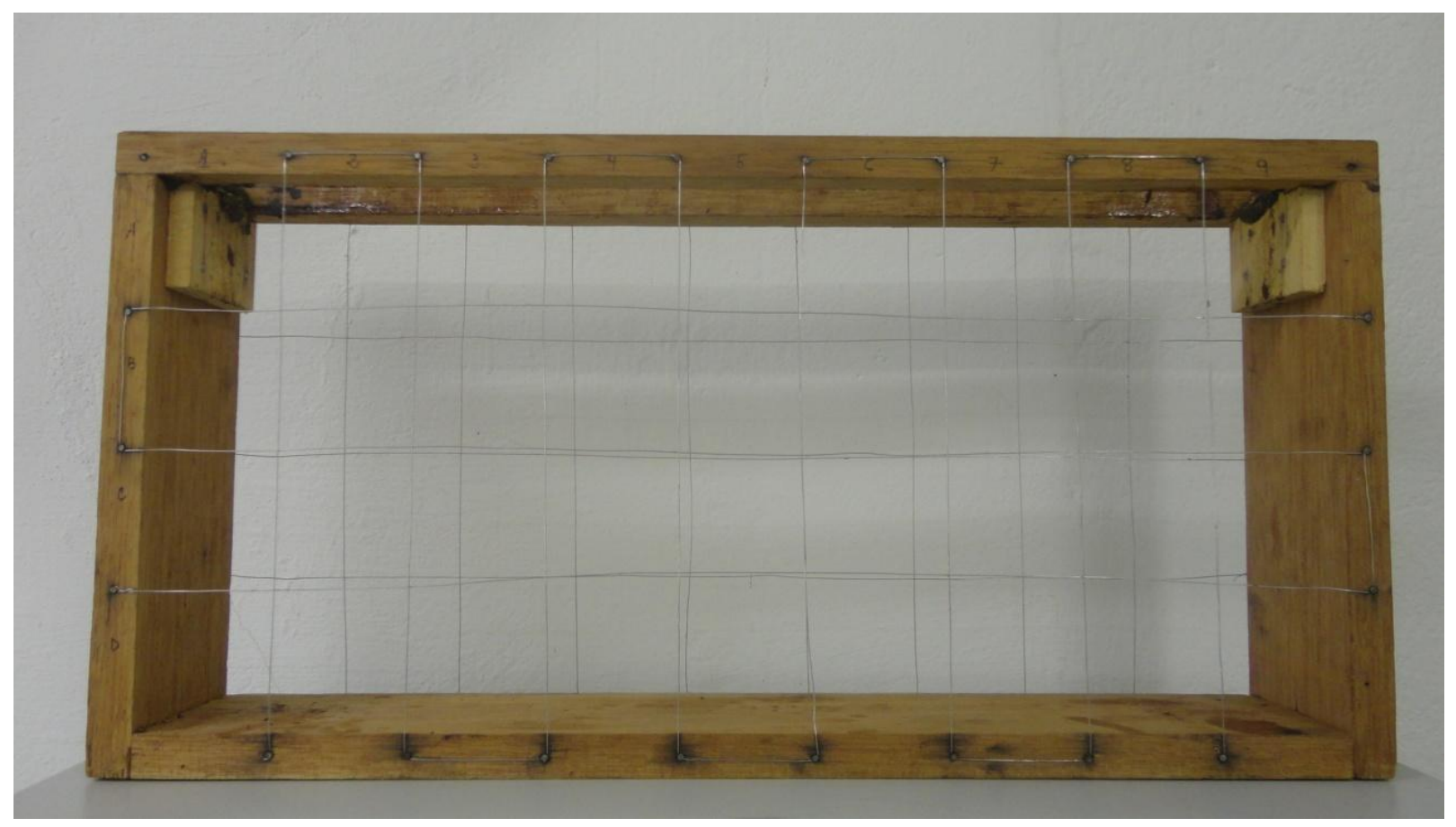

Figura 14: Suporte de madeira com laterais construídas de arame esticado, formando quadrados de $5 \mathrm{~cm}$ de lado. (Foto: Joyce M. V. Almeida)

\subsubsection{Determinação da taxa de consumo e preferência de cada dieta no campo}

Para esta etapa do experimento, foram analisadas a taxa de consumo e a preferência de cada dieta. Para os experimentos relacionados ao consumo, foram utilizados 04 núcleos. Para cada núcleo, foram fornecidos $100 \mathrm{~g}$ das dietas D3 e D4, dois núcleos para cada dieta. O consumo foi medido a cada quatro dias e anotado para análises posteriores.

Para a mensuração da taxa de preferência, foram utilizados três núcleos, no qual as dietas D3 e D4 foram oferecidas ao mesmo tempo (50 g de cada dieta), para que essas abelhas pudessem ter a opção de escolher qual dieta consumir. $\mathrm{O}$ peso da sobra dessas dietas foi medido de dois e dois dias e anotado para análises posteriores. 


\subsection{Análise Estatística}

A concentração total da hemolinfa das abelhas alimentadas com as diferentes dietas foi comparada com a concentração total da hemolinfa das abelhas tratadas com o controle positivo (dieta D1) a fim de termos um parâmetro de comparação da qualidade da dieta fermentada. Primeiramente os dados foram testados quanto à sua normalidade e em seguida, comparados através de um teste ANOVA on Ranks $(\alpha=0,05)$ no software SigmaStat 3.5. 


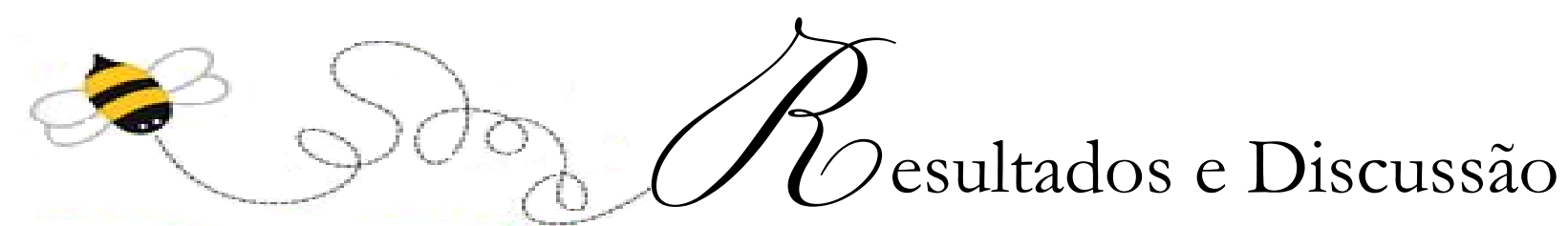




\section{Resultados e Discussão}

\subsection{Determinação da concentração de proteína total na hemolinfa de operárias confinadas em gaiola}

Para este experimento, foram oferecidas quatro sendo duas dessas classificadas como controle positivo (Dieta D1) e controle negativo (Dieta D2). A determinação da concentração de proteína total na hemolinfa foi medida em dois momentos, ou seja, com três dias de alimentação e com sete dias de alimentação, onde foram encerrados os experimentos.

Com três dias de alimentação, verificamos que a dieta D3 e D4 não apresentaram diferença estatística significativa em relação ao controle positivo, $\mathrm{p}=0,809$ e $\mathrm{p}=0,437$, respectivamente. Enquanto que em relação ao controle negativo as duas dietas (D3 e D4) e o controle positivo apresentaram diferença estatística significativa $(\mathrm{p}=0,007)$.

A média dos níveis de proteína na hemolinfa $(\mu \mathrm{g} / \mu \mathrm{l})$ das abelhas alimentadas com as diferentes dietas no período de três dias foi respectivamente: Controle Positivo: 23,00 $\mu \mathrm{g} / \mu \mathrm{l}$; Controle Negativo: 14,38 $\mu \mathrm{g} / \mu \mathrm{l}$; D3: 23,65 $\mu \mathrm{g} / \mu \mathrm{l}$ e D4: $26,15 \mu \mathrm{g} / \mu \mathrm{l}$ (Figura 15). 


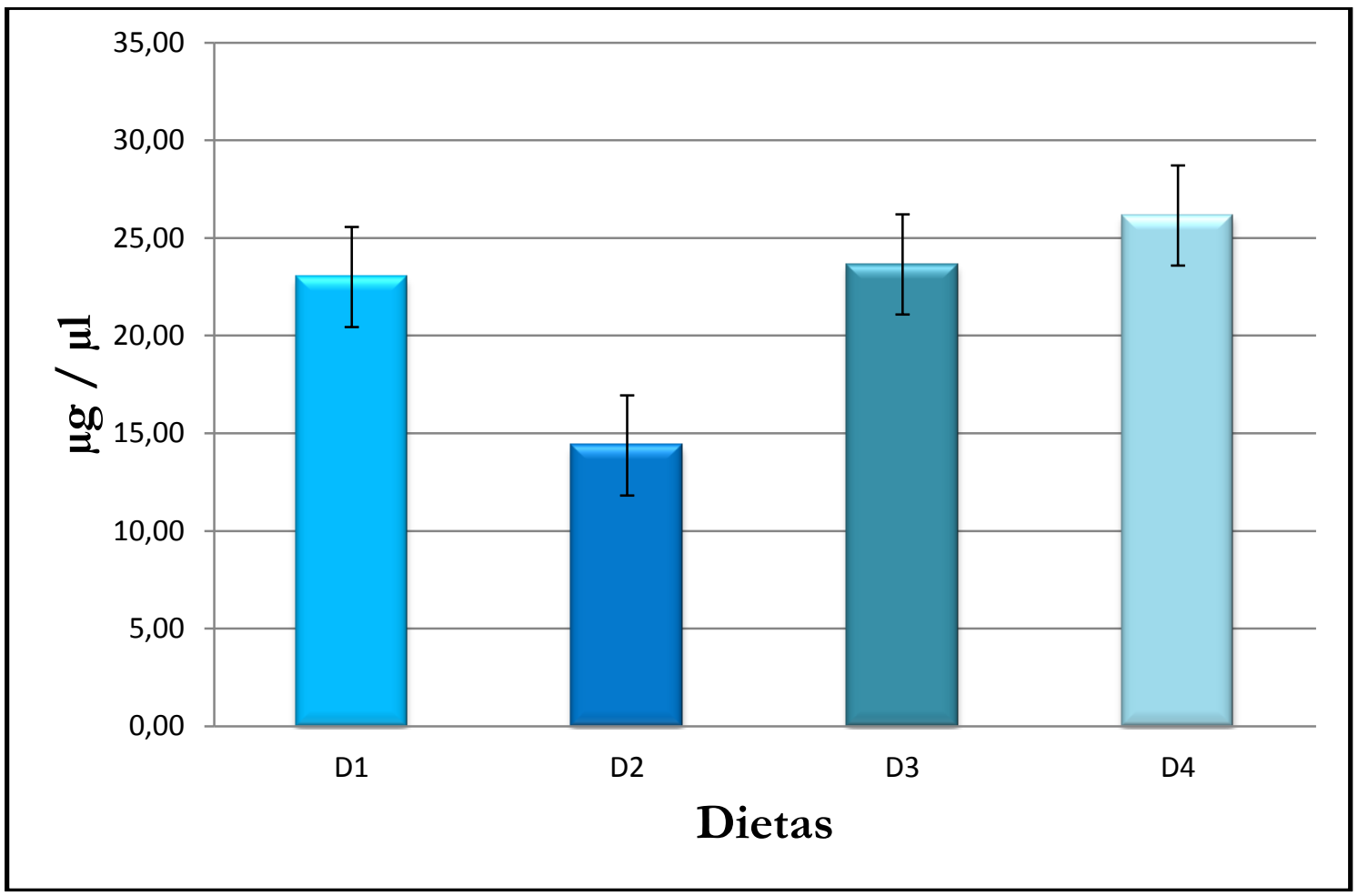

Figura 15: Níveis de proteína na hemolinfa $(\mu \mathrm{g} / \mu \mathrm{l})$ das abelhas recém-nascidas alimentadas com as diferentes dietas durante três dias.

Já com sete dias de alimentação, verificou-se que tanto a dieta D3 quanto a dieta $\mathrm{D} 4$, apresentaram diferenças estatísticas significativas em relação ao controle positivo, cujos valores foram $\mathrm{p} \leq 0,001$ e $\mathrm{p}=0,007$, para as dietas D3 e D4, respectivamente.

Nossos dados estão de acordo com os encontrados por Turcatto, 2011 e Morais et al., (submetido), onde também foi encontrada uma diferença significativa entre dietas artificiais proteicas e o controle positivo em relação ao controle negativo .

De acordo com Crailsheim (1990) e seus colaboradores (1992) a disponibilidade de proteína, e principalmente, a concentração desta no pólen, é essencial para o crescimento da cria. Portanto, a síntese de proteína pelas abelhas é influenciada por muitos fatores, como por exemplo, a alimentação, uma vez que desta, provém o material e energia necessários à síntese proteica. Nossos dados mostraram que as dietas testadas (D3 e D4), promoveram a síntese de 
proteína em níveis normais, corroborando dessa maneira com os resultados obtidos por Turcatto, 2011.

A média dos níveis de proteína na hemolinfa $(\mu \mathrm{g} / \mu \mathrm{l})$ das abelhas alimentadas com as diferentes dietas no período de sete dias foi respectivamente: Controle Positivo: 54,29 $\mu \mathrm{g} / \mu \mathrm{l}$; Controle Negativo: 12,14 $\mu \mathrm{g} / \mu \mathrm{l}$; D3: 32,24 $\mu \mathrm{g} / \mu \mathrm{l}$ e D4: 39,46 $\mu \mathrm{g} / \mu \mathrm{l}$ (Figura 16).

Nossos dados mostraram que as dietas D3 e D4 promovem a síntese de proteína como as abelhas que consumiram "Beebread", que é a fonte natural de proteína dessas abelhas.

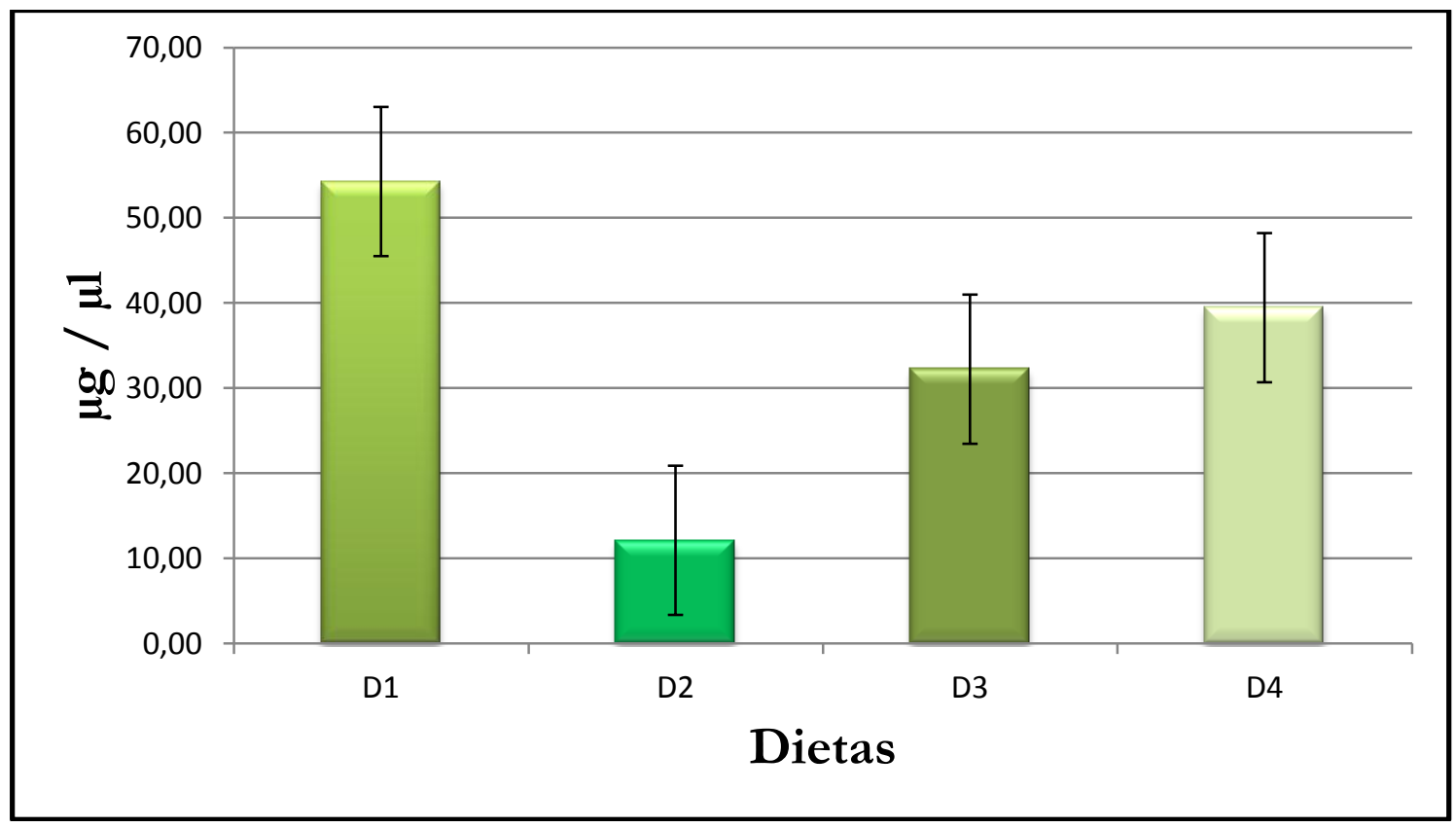

Figura 16: Níveis de proteína na hemolinfa $(\mu \mathrm{g} / \mu \mathrm{l})$ das abelhas alimentadas com as diferentes dietas durante de sete dias.

$\mathrm{Na}$ Natureza, em períodos de baixa disponibilidade de proteína, o fornecimento de dietas alternativas como forma de suplementação pode ajudar a melhorar o desempenho da colônia até a melhora das condições ambientais (Cremonez, 1996). Sendo assim, a oferta de alimento proteico em seguida a um período de escassez causa a recuperação da vitalidade da colônia, que rapidamente converte o alimento em estoques de pólen e produção de crias, 
demonstrando a melhora no estado nutricional das abelhas (Cremonez et al., 1998).

Nossos dados corroboram com os encontrados por Cremonez, 2001, no qual os títulos mais altos de proteína foram encontrados nos grupos que consumiram pólen como fonte alimentar proteica (Figura 17).

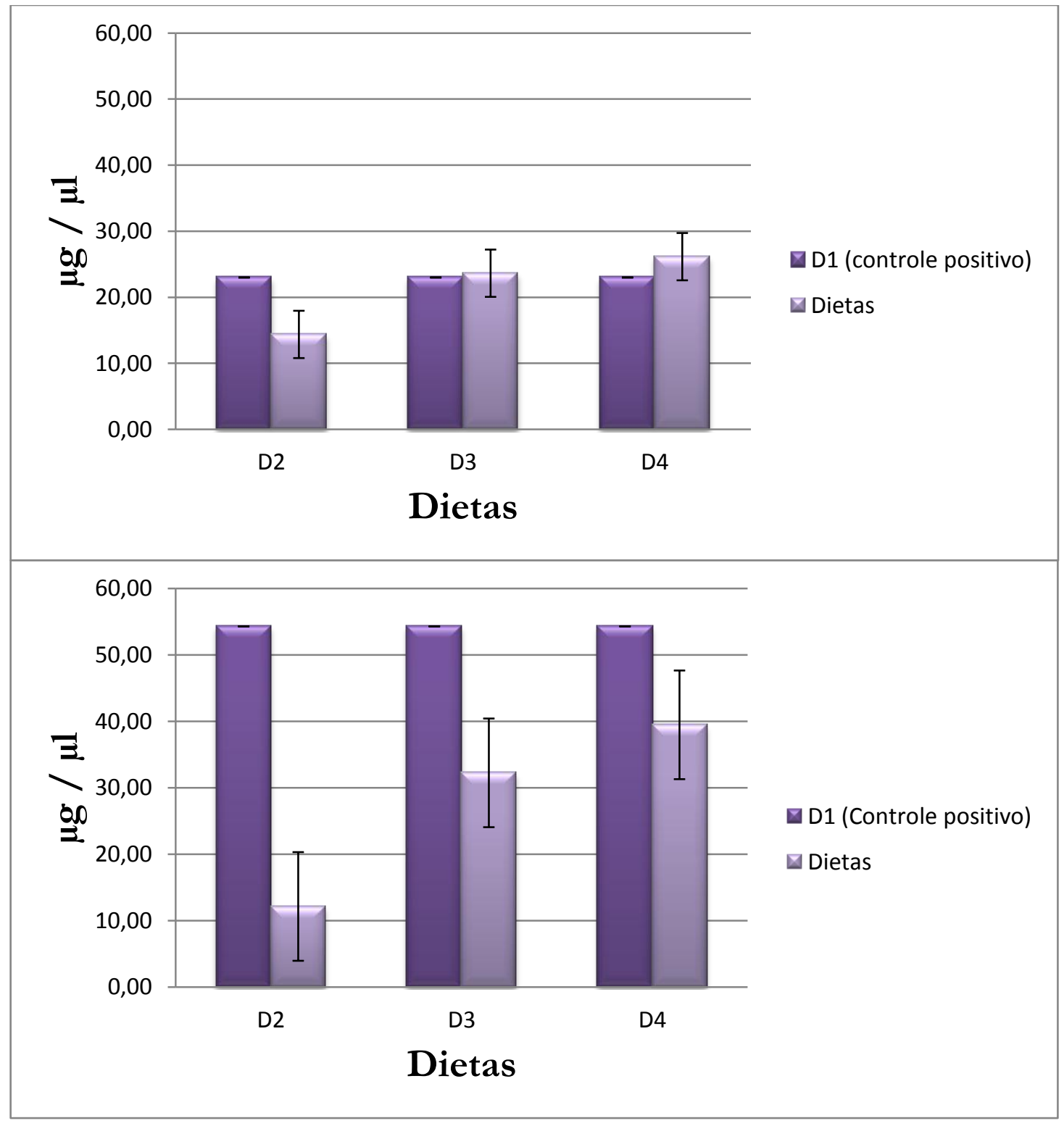

Figura 17: A - Comparação ( $\mu \mathrm{g}$ de proteína por $\mu \mathrm{L}$ de hemolinfa) entre o Controle Positivo (D1), Controle Negativo (D2) e as dietas (D3 e D4) com 3 dias de alimentação; B - Comparação entre o Controle Positivo (D1), Controle Negativo (D2) e as dietas (D3 e D4) com 7 dias de alimentação. 
Da mesma forma que o encontrado por Haydak (1935) in Cremonez et al., 1998, verificamos que abelhas alimentadas apenas com carboidratos (controle negativo) apresentam um decréscimo na concentração de proteína na hemolinfa (Figura 18). E sendo assim, a dieta de xarope (controle negativo) não permitiu a síntese de proteína total em níveis normais.

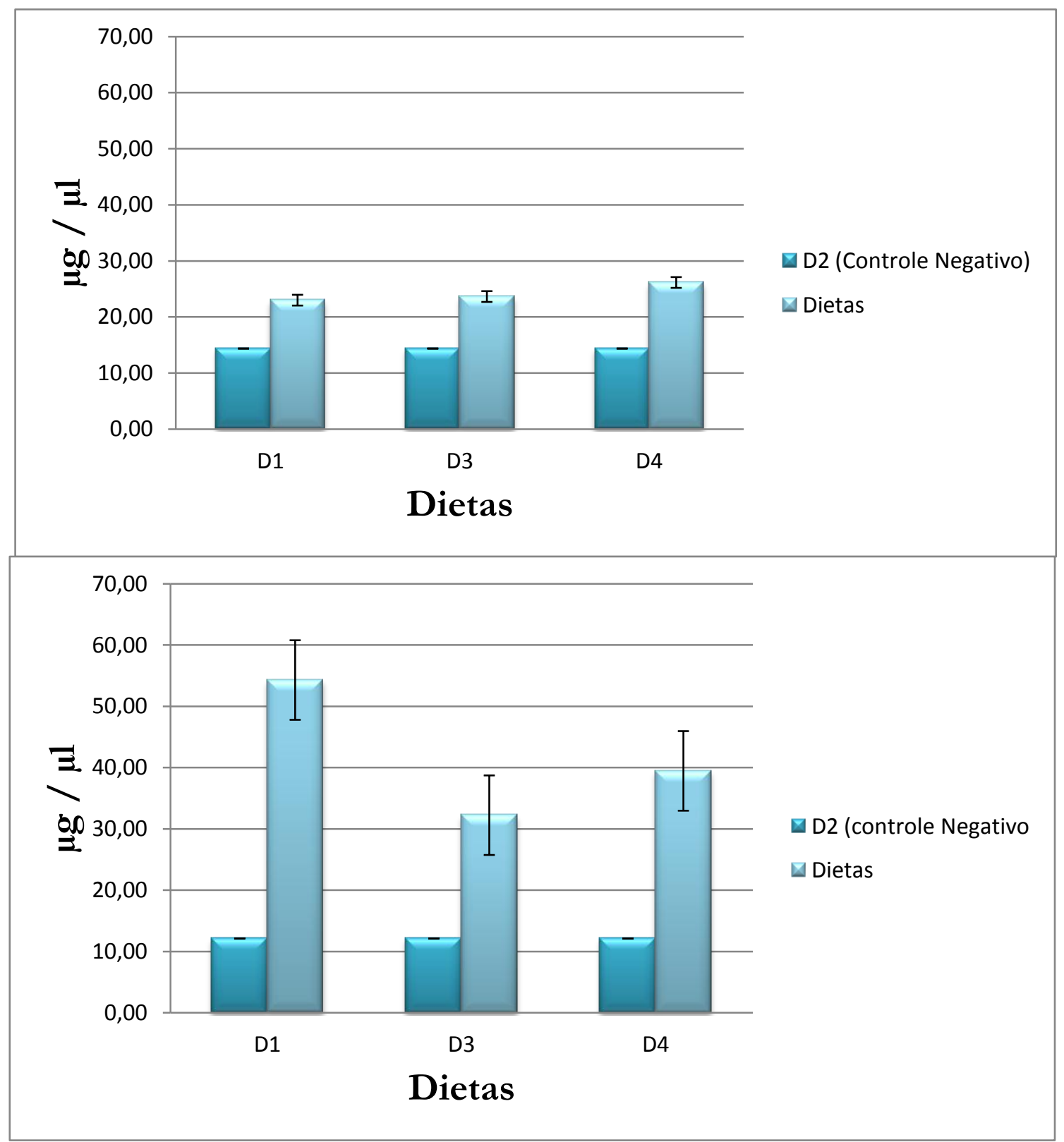

Figura 18: A - Comparação ( $\mu$ g de proteína por $\mu \mathrm{l}$ de hemolinfa) entre o Controle Negativo (D2) e as dietas (Controle Positivo - D1; D3 e D4) com 3 dias de alimentação; B Comparação entre o Controle Negativo (D2) e as dietas (Controle Positivo - D1; D3 e D4) com 7 dias de alimentação. 
Os resultados obtidos no presente estudo estão de acordo com os encontrados por Van der Steen (2007), que mostrou um aumento progressivo no título da proteína na hemolinfa das abelhas alimentadas com algum alimento proteico ou pólen, e uma redução de proteína foi observada nas abelhas alimentadas com sacarose.

Resultados similares aos nossos foram reportados por De Jong et al., (2009), os quais registraram que operárias alimentadas com carboidrato apenas, apresentam baixos títulos de proteína na hemolinfa.

De acordo Standifer e colaboradores (1973) certas dietas artificiais ou substitutos de pólen oferecidos às abelhas poderiam ter o mesmo valor nutritivo ou até superar o valor nutritivo do pólen. Nossos dados mostraram que a dieta D4, a dieta fermentada, apresentou diferença estatística significativa em relação à dieta D3, a dieta não fermentada $(\mathrm{p}=0,021)$ na hemolinfa das abelhas alimentadas no período de sete dias (Figura 19).

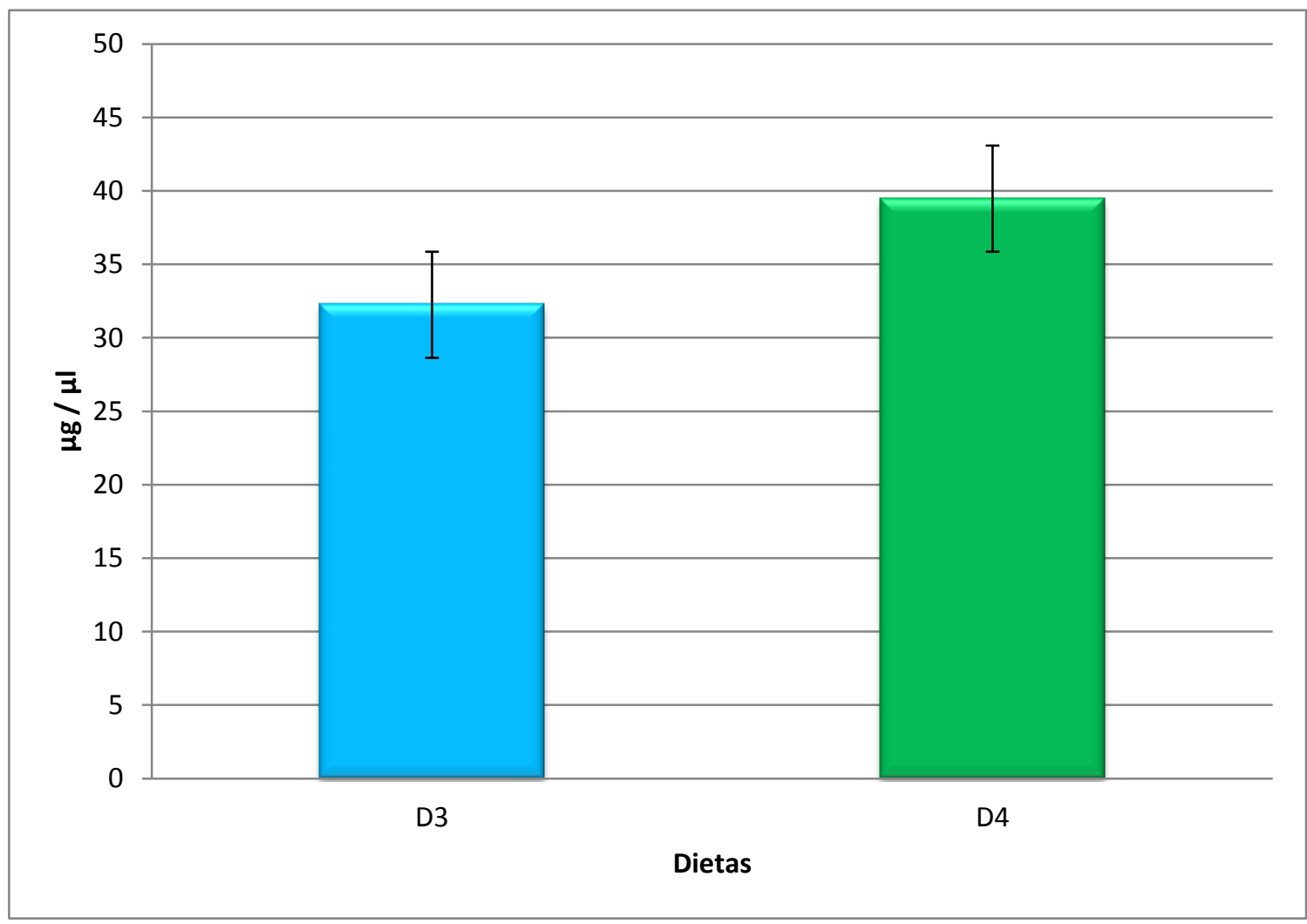

Figura 19: Comparação ( $\mu \mathrm{g}$ de proteína por $\mu \mathrm{l}$ de hemolinfa) na hemolinfa de abelhas alimentadas com a dieta proteica (D3) e a Dieta proteica fermentada (D4) com sete dias de alimentação. 
A determinação da concentração de proteína na hemolinfa de operárias é um método preciso para avaliar a eficiência de dietas ricas em proteínas. Os dados mostram uma grande variabilidade nos títulos de proteína na hemolinfa de abelhas alimentadas com dietas diferentes. O teste de pequenos grupos de abelhas em gaiolas tem várias vantagens, pois os testes são relativamente rápidos, com baixos gastos de materiais e, além disso, a alimentação das abelhas em gaiolas não sofre interferência de fatores externos.

\subsection{Padrão eletroforético para proteínas totais}

Baseado nos dados das análises de proteínas totais através do método de Bradford (1976) da hemolinfa de abelhas alimentadas no período de sete dias com as dietas D1 (Controle Positivo), D2 (Controle Negativo), D3 (Dieta não fermentada) e D4 (Dieta Fermentada), foi realizadas análises eletroforéticas (SDS-PAGE) destas amostras a fim de verificar como essa diferença é refletida no padrão proteico de cada grupo analisado. No gel as amostras aplicadas, foram padronizadas baseando-se no volume de hemolinfa o que denominamos Gel de "Volume fixo".

Conforme exposto na Figura 20, o perfil proteico da hemolinfa das operárias tratadas com as dietas artificial D3 e D4 foi semelhante ao perfil das operárias alimentadas com "Beebread" (D1 - Controle Positivo). Este resultado indica que as dietas proteicas artificiais testadas foram capazes de fornecer aminoácidos necessários para a síntese de proteínas próprias da fisiologia de uma operária alimentada com sua dieta natural ("Beebread"). 


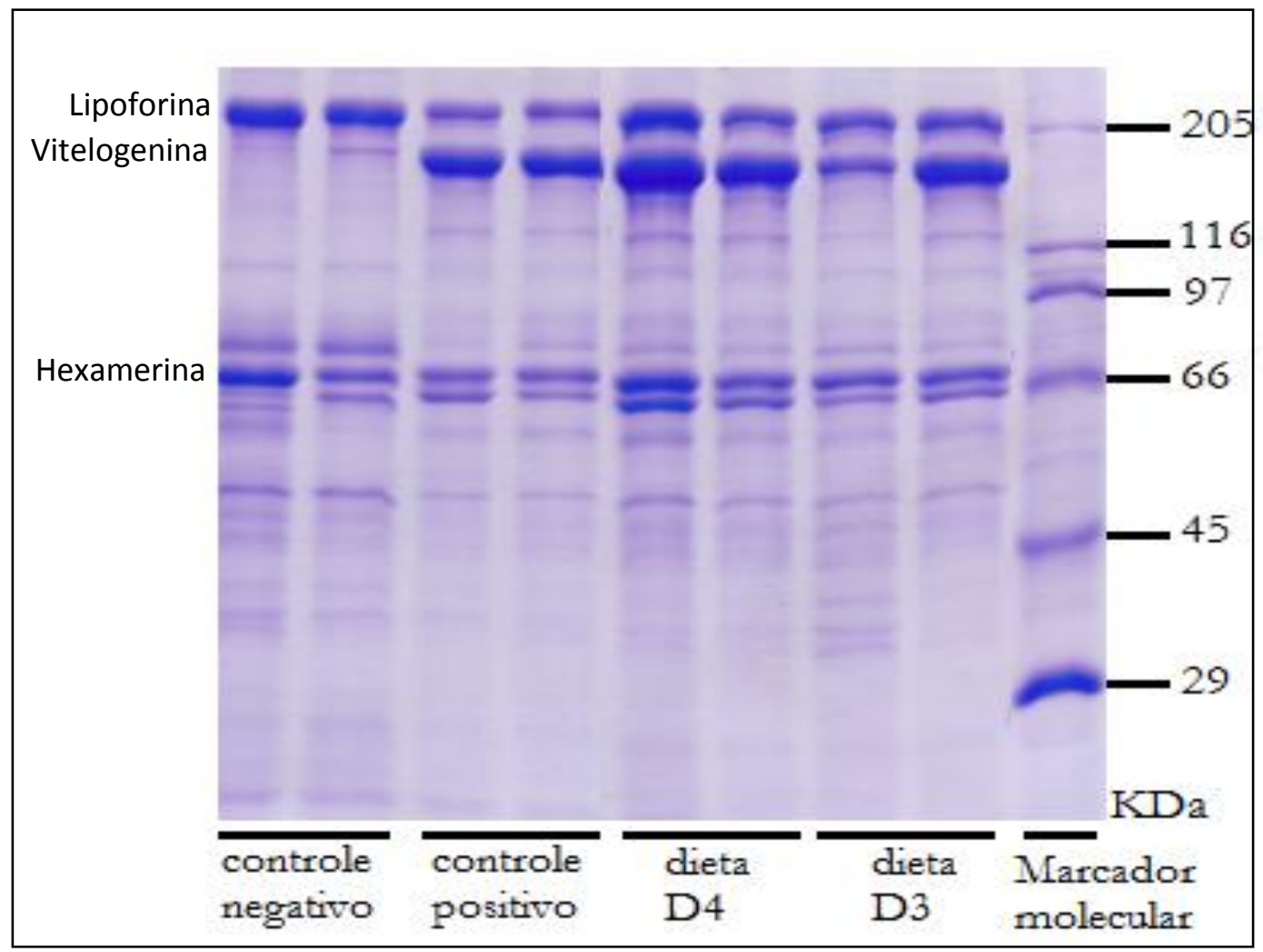

Figura 20: Gel de poliacrilamida SDS-PAGE corado com Coomassie Brillant Blue, mostrando padrões de proteína na hemolinfa de operárias de abelhas $A$. mellifera alimentadas com diferentes dietas: Xarope (Controle Negativo); "Beebread" (Controle Positivo), dieta fermentada (D4) e dieta não fermentada (D3). Marcadores de massa molecular $(\mathrm{kDa})$ estão indicadas à direita.

Em A. mellifera, o acúmulo das proteínas de estocagem, a Vitelogenina (Vg) (Bitondi e Simões, 1996) e hexamerinas (Cunha et al., 2005; Bitondi et al., 2006; Martins et al., 2008) na hemolinfa das operárias adultas é significantemente influenciado pela nutrição. Assim, uma nutrição adequada capaz de manter quantitativa e qualitativamente os perfis de proteína na hemolinfa das abelhas melíferas garante a correta manutenção da fisiologia e comportamento dessas abelhas.

O corpo gorduroso é o órgão exclusivo de síntese de $\mathrm{Vg}$ na maioria dos insetos (Valle, 1993). Esta glicoproteína possui peso molecular ao redor de 180 kDa (Piulachs et al., 2003). Todavia, já foi descrito em várias espécies de 
insetos a produção de $\mathrm{Vg}$ também pelos ovários. Também foi evidenciada a produção de Vg pelos ovários em outras espécies de insetos como, Coccinella septempuctata (Melo et al., 2000).

A Vg das abelhas melíferas está envolvida em vários outros processos biológicos além da reprodução, como longevidade, imunidade, transporte de zinco e principalmente a síntese de alimento larval (Amdam et al., 2004; Amdam et al., 2005).

Através da Figura 21, pode-se observar que somente nos lugares onde foram aplicadas as amostras do Controle Positivo e das Dietas D3 e D4, houve a expressão da proteína Vitelogenina, comprovando mais uma vez a eficácia das duas dietas artificiais.

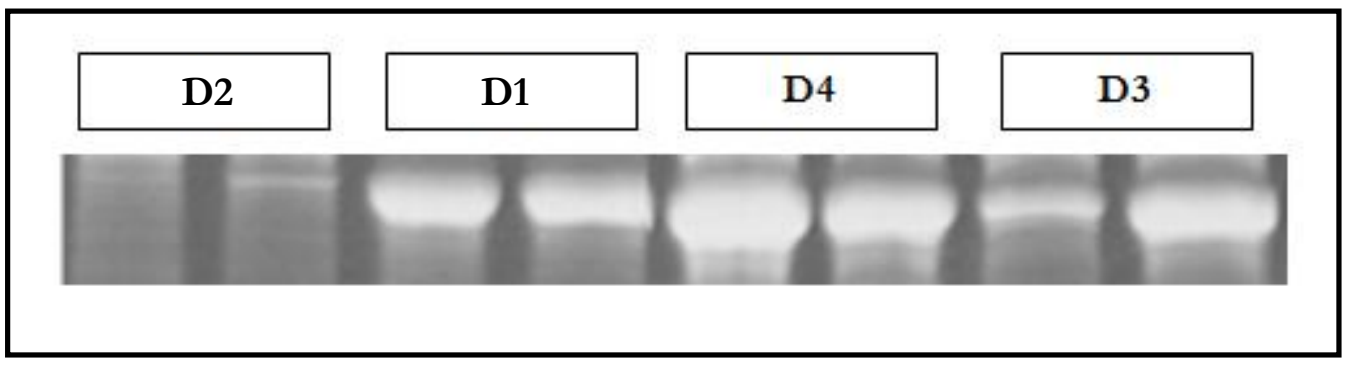

Figura 21: Bandas de Vitelogenina em abelhas alimentadas durante sete dias, em gel SDS-PAGE. Gel padronizado no volume aplicado de amostras de hemolinfa. D1 (Controle Positivo - Beebread); D2 (Controle Negativo - Xarope de Sacarore); D3 (Dieta proteica não fermentada); D4 (Dieta proteica fermentada).

Apesar das duas dietas artificiais D3 e D4 expressarem a proteína Vg na hemolinfa das abelhas alimentada, para afirmar verdadeiramente os resultados obtidos através das análises de quantificação total de proteínas na hemolinfa, onde a Dieta D4 é significantemente diferente da Dieta D3, realizamos a densitometria das bandas da proteína Vg, entre as dietas D3 e D4 .Os dados obtidos confirmam que a densidade das bandas de $\mathrm{Vg}$, da dieta D4 possui diferença estatística significativa em relação aos encontrados da dieta D3, com 
um valor de $p=0,0027$. Isso demonstra mais uma vez que, as operárias confinadas e alimentadas com a Dieta D4 expressaram normalmente uma das principais proteínas de estocagem, a Vitelogenina, melhor às alimentadas com a Dieta D3 (Figura 22).

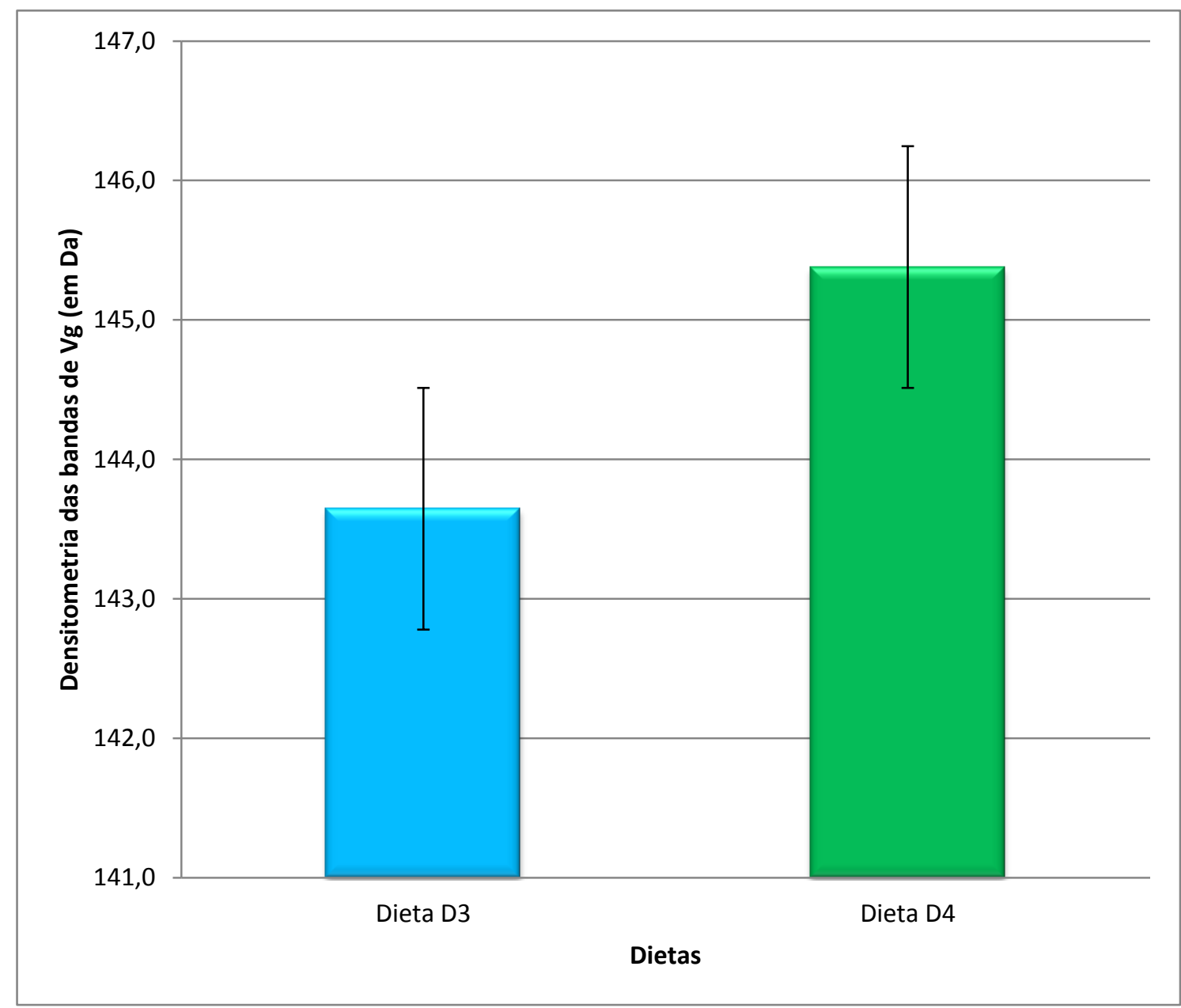

Figura 22: Quantificação densitométrica da intensidade de bandas correspondentes à vitelogenina em abelhas alimentadas durante 7 dias com a dieta não fermentada (D3) e a dieta fermentada (D4) em gel SDS-PAGE.

Outra proteína importante observada no gel de poliacrilamida feito (foi à presença da proteína Lipoforina (Lp). Nos insetos, a Lp representa a maior lipoproteína presente na hemolinfa, e é composta por duas apolipoproteínas, apoLp - I (210 - $250 \mathrm{kDa})$ e apoLp - II (70 - 85 kDa) (Lazzarini, 2006). 
Em termos funcionais, a principal função da Lp é transportar lipídios entre os sítios de absorção no intestino e os locais de depósito nas células do corpo gorduroso ou de utilização nos músculos e outros tecidos (Lazzarini, 2006).

Podemos observar na Figura 23 que todas as amostras aplicadas possuem expressão da proteína lipoforina. Através da análise densitométrica dessas bandas no gel de SDS-PAGE, verificamos que não há diferença estatística se compararmos os grupos de amostras das duas dietas artificiais aplicadas no gel (D3 e D4), $\mathrm{p}=0,927$ (Figura 24).

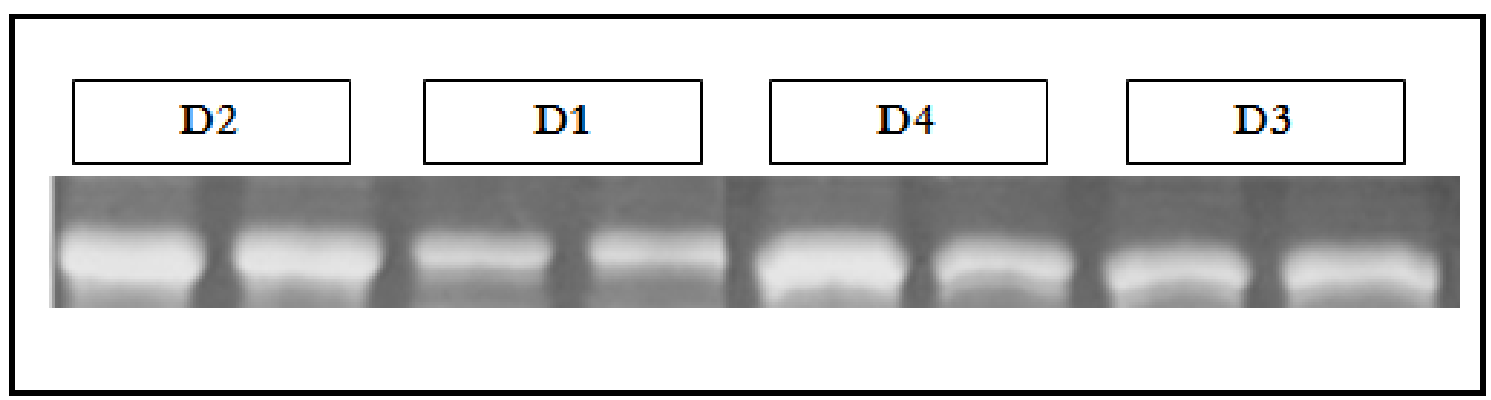

Figura 23: Bandas de Lipoforina em abelhas alimentadas durante sete dias, em gel SDSPAGE. Gel padronizado no volume aplicado de amostras de hemolinfa. D1 (Controle Positivo - Beebread); D2 (Controle Negativo - Xarope de sacarose); D3 (Dieta proteica não fermentada); D4 (Dieta proteica fermentada). 


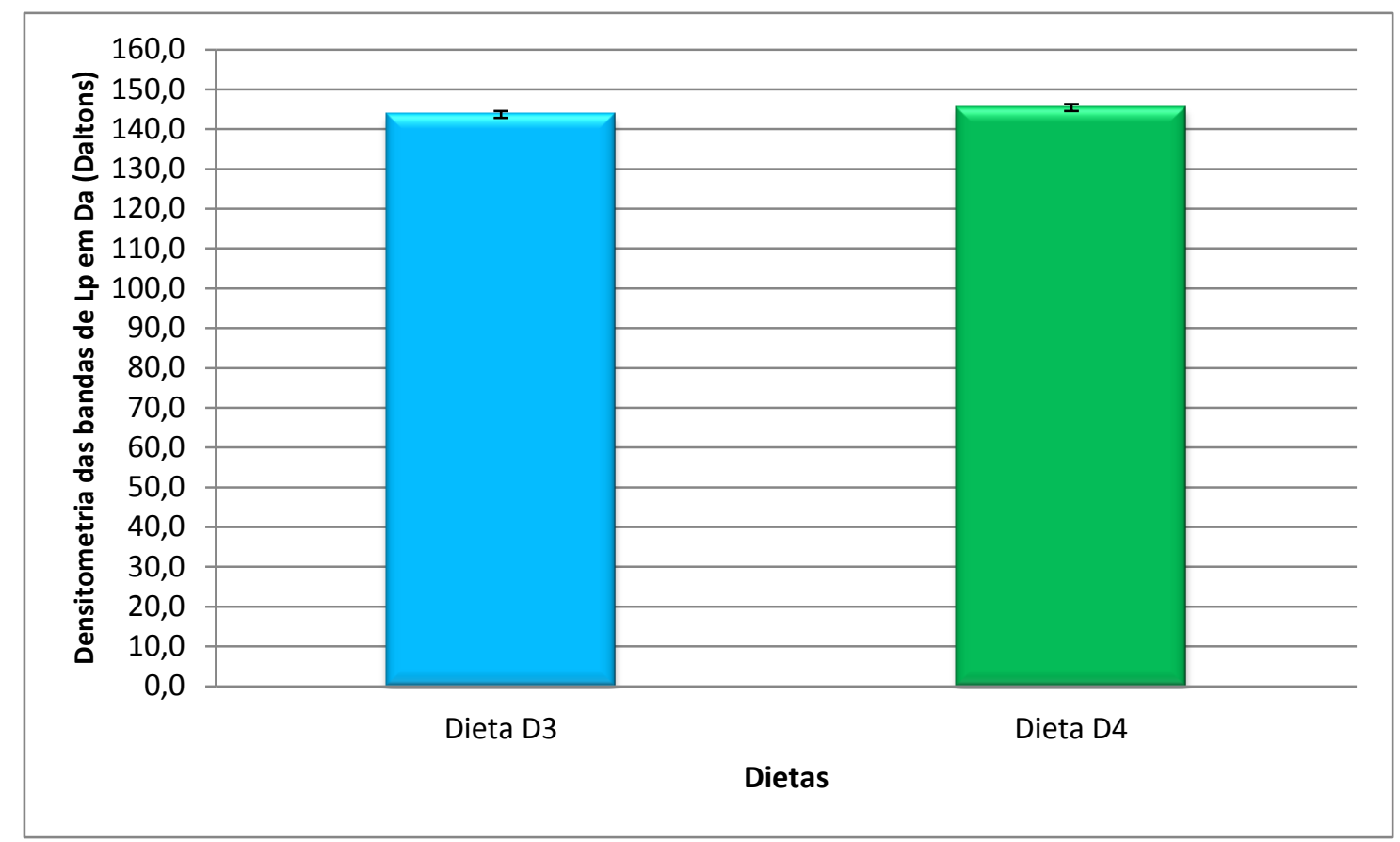

Figura 24: Quantificação densitométrica da intensidade de bandas correspondentes à lipoforina em abelhas alimentadas com a dieta não fermentada (D3) e a dieta fermentada (D4) em gel SDS-PAGE.

\subsection{Avaliação da taxa de sobrevivência de abelhas operárias adultas confinadas em laboratório}

Estudos de longevidade realizados por Schmidt (1984) mostraram que o baixo consumo de pólen ocorre pela falta de substâncias atrativas, presença de elementos tóxicos naturais ou um pobre balanço de nutrientes. Um ou mais fatores podem estar associados, entre eles a quantidade inadequada de aminoácidos essenciais e de proteína que o mesmo contenha.

Através das análises das médias (Tabela 2), podemos observar que a taxa de sobrevivência das abelhas que se alimentaram das dietas D1, D3 e D4 possui diferença estatística em relação àquelas alimentadas somente com o controle negativo $(\mathbf{D} 2),(\mathrm{p} \leq 0,001)$. 
Tabela 2: Médias da taxa de sobrevivência de operárias de abelhas $A$. mellifera confinadas e alimentadas com diferentes dietas energético-proteicas.

\begin{tabular}{c|c}
\hline \hline Dietas & $\begin{array}{c}\text { Médias da taxa de sobrevivência } \\
\text { durante 28 dias (\%) }\end{array}$ \\
\hline D1 (Controle Positivo) & 72,04 \\
D2 (Controle Negativo) & 43,24 \\
D3 (Dieta não fermentada) & 61,63 \\
D4 (Dieta fermentada) & 70,63 \\
\hline
\end{tabular}

Já quando comparamos as dietas artificiais (D3 e D4) com o controle positivo (D1), não há diferença estatística $(\mathrm{p}=0,188)$, mostrando assim que essas dietas são muito próximas ao alimento natural, o Beebread, que nesse trabalho é utilizado como controle positivo (Figura 25). Entre as dietas D3 e D4 também não há diferença estatística em relação à taxa de sobrevivência, p=0,178. 


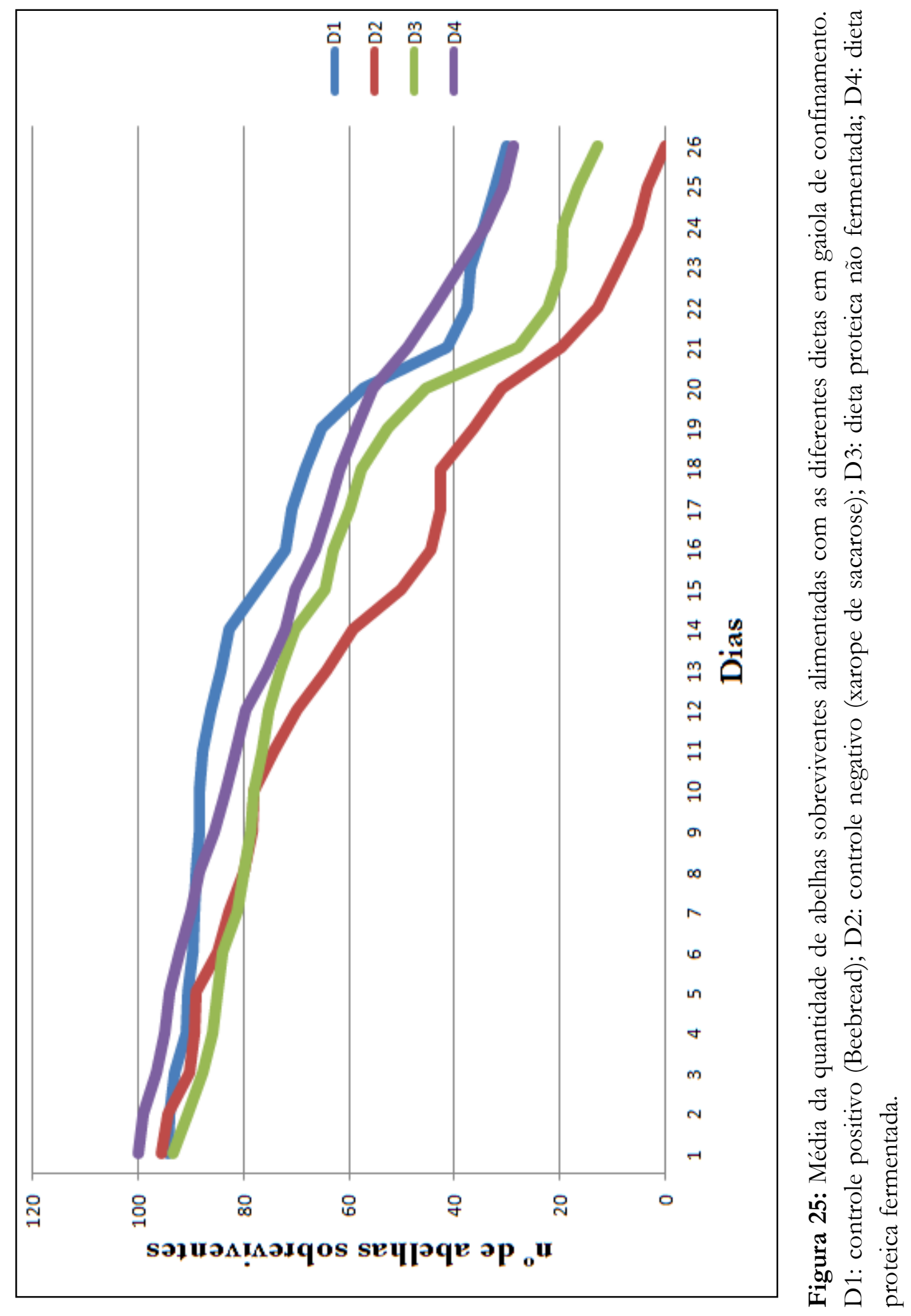

63 
Nossos dados vêm de encontro aos encontrados por Schmidt et al., (1987), onde alimentaram abelhas $A$. mellifera com vinte e cinco variedades de pólen e avaliaram a longevidade média destas abelhas frente a controles que receberam apenas açúcar e água. Os autores observaram grande variação na quantidade de pólen consumido e na longevidade das abelhas, e atribuíram essas diferenças à concentração de proteína do pólen consumido.

\subsection{Determinação da taxa de consumo e preferência de cada dieta}

\subsection{1. $\quad 1^{\circ}$ Experimento: Laboratório}

Durante os sete dias de fornecimento das dietas (D3 e D4) em gaiolas de confinamento, foi medido o consumo total destas. A dieta D4 foi estatisticamente diferente em relação ao consumo da dieta $\mathbf{D 3},(p=0,002)$, mostrando assim que as abelhas consomem mais a dieta fermentada (Figura 26), semelhante ao Beebread. Nossos dados estão de acordo aos encontrados por Herbert e Shimanuki 1978, onde os substitutos de pólen executam eficientemente todas as funções do pólen, mas a principal dificuldade é a aceitação pelas abelhas, pois os substitutos necessitam ser além de nutritivos, palatáveis para as abelhas, pois precisa ser o mais semelhante possível ao alimento natural desses insetos, o Beebread. 


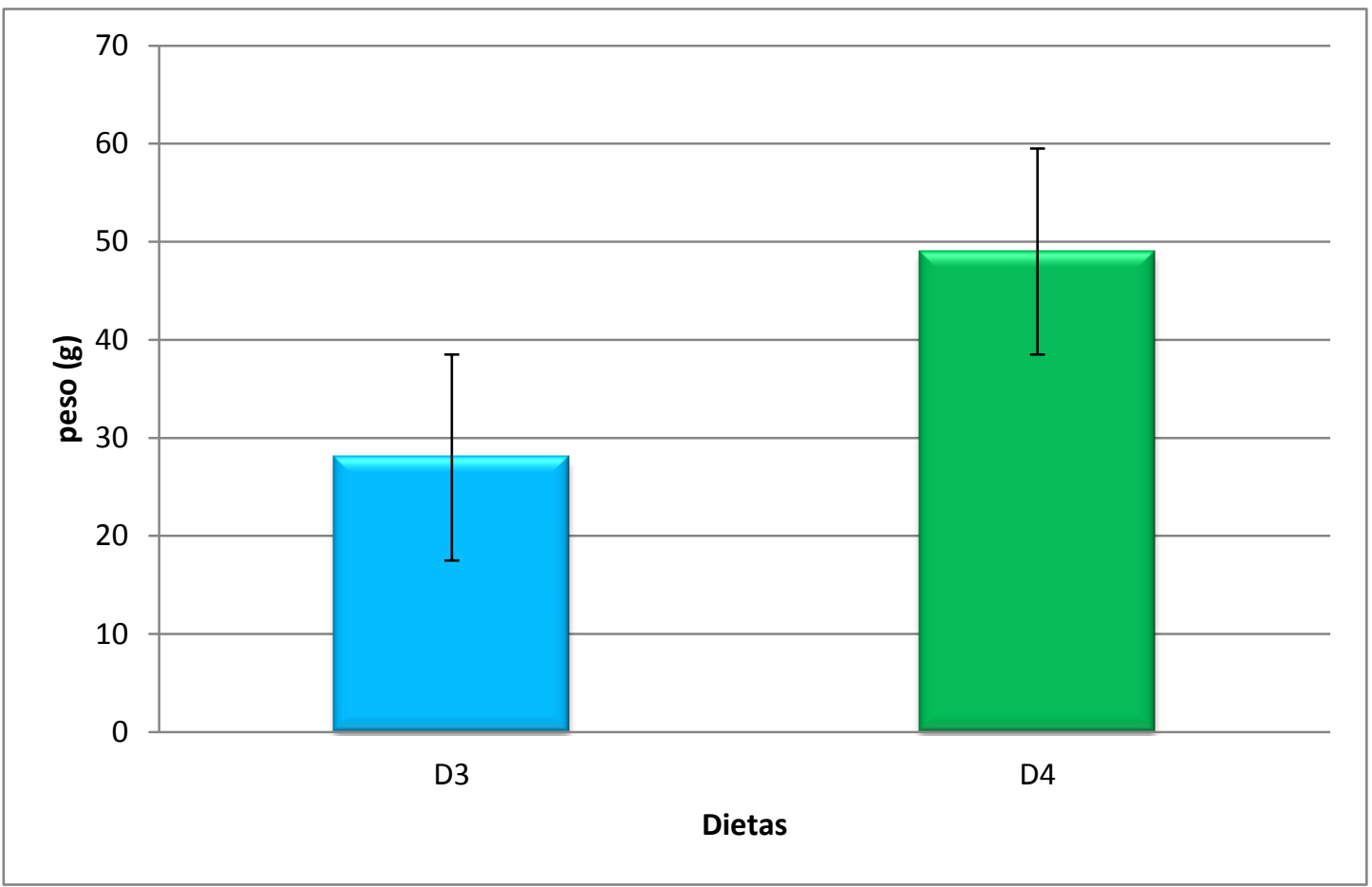

Figura 26: Comparação das médias taxas de consumo (peso em gramas) entre as dietas D3 (dieta não fermentada) e D4 (dieta fermentada) em gaiolas de confinamento durante 28 dias.

Em relação à taxa de preferência, após sete dias de experimentos, verificamos que quando as duas dietas (D3 e D4) são oferecidas em conjunto, em uma mesma gaiola de confinamento, as abelhas preferem a dieta D4 (dieta fermentada) (Figura 27). Nossos dados mostram que a dieta D3 possui diferença estatística em relação à dieta $\mathbf{D} 4(\mathrm{p} \leq 0,001)$. 


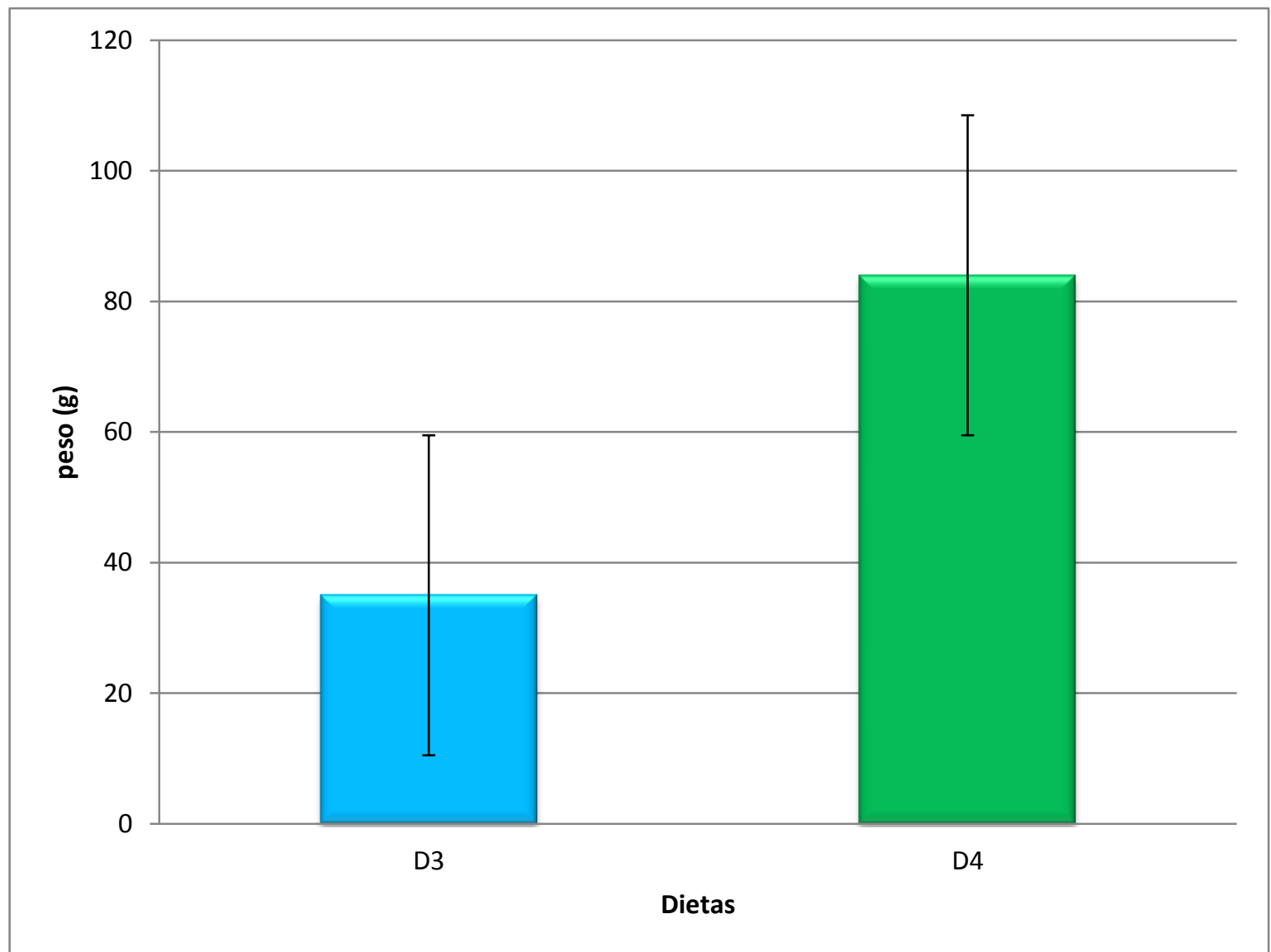

Figura 27: Comparação das médias taxas de preferência (peso em gramas) entre as dietas D3 (dieta não fermentada) e D4 (dieta fermentada) em gaiolas de confinamento.

\subsection{2. $2^{\circ}$ Experimento: Campo}

Para os experimentos no campo, analisamos os mesmos parâmetros (consumo e preferência) que no laboratório. Neste experimento utilizamos quatro núcleos padronizados, em relação à quantidade de quadros de cria e quadros de alimento. Sendo dois desses núcleos para a dieta D3, e dois para a dieta D4.

Ao analisarmos o consumo dessas dietas nas colônias, verificamos que a dieta D3 apresentou diferença estatística em relação à dieta D4 ( $\leq \leq 0,001)$, mostrando assim que as abelhas no campo consomem muito mais a dieta 
fermentada (D4) do que a dieta não fermentada (D3), Figura 28. Nossos dados assemelham-se aos encontrados por Ellis et al., 2009 onde, do mesmo modo, houve um maior consumo de dietas fermentadas do que dietas não fermentadas.

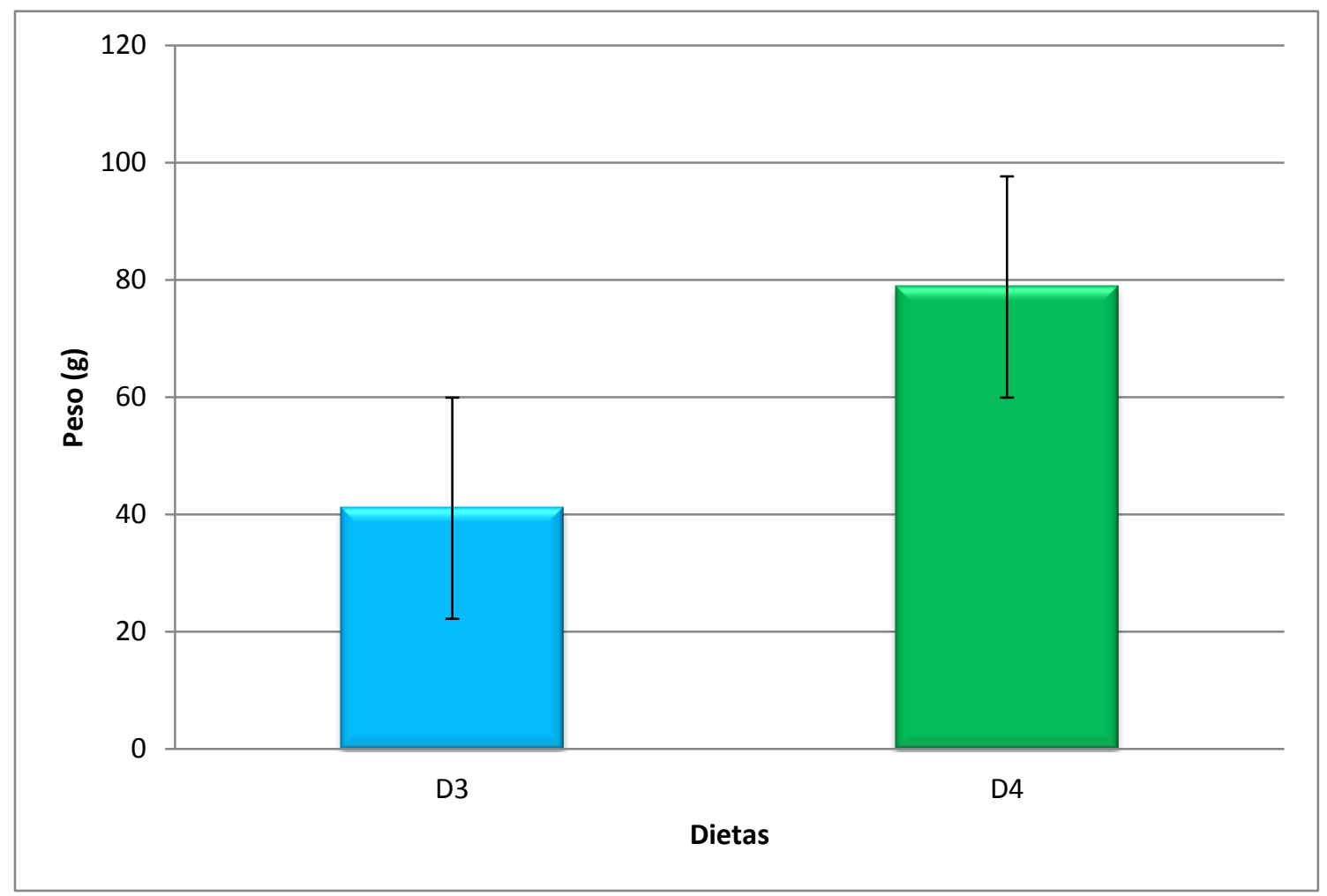

Figura 28: Comparação das médias taxas de consumo (peso em gramas) entre as dietas D3 (dieta não fermentada) e D4 (dieta fermentada) em núcleos no campo durante 7 dias.

Os dados relacionados à preferência dessas abelhas no campo, as abelhas preferiram a dieta $\mathbf{D} 4$, com consumo total de $165 \mathrm{~g}$, do que a dieta $\mathbf{D} 3$, com consumo de $154 \mathrm{~g}$, porém não houve diferença significativa, $\mathrm{p}=0,850$. Nossos dados, mais uma vez, corroboram com os encontrados por Ellis et al., 2009, onde as abelhas preferiram em mais uma dieta que possui soja e é fermentada do que uma não fermentada. 


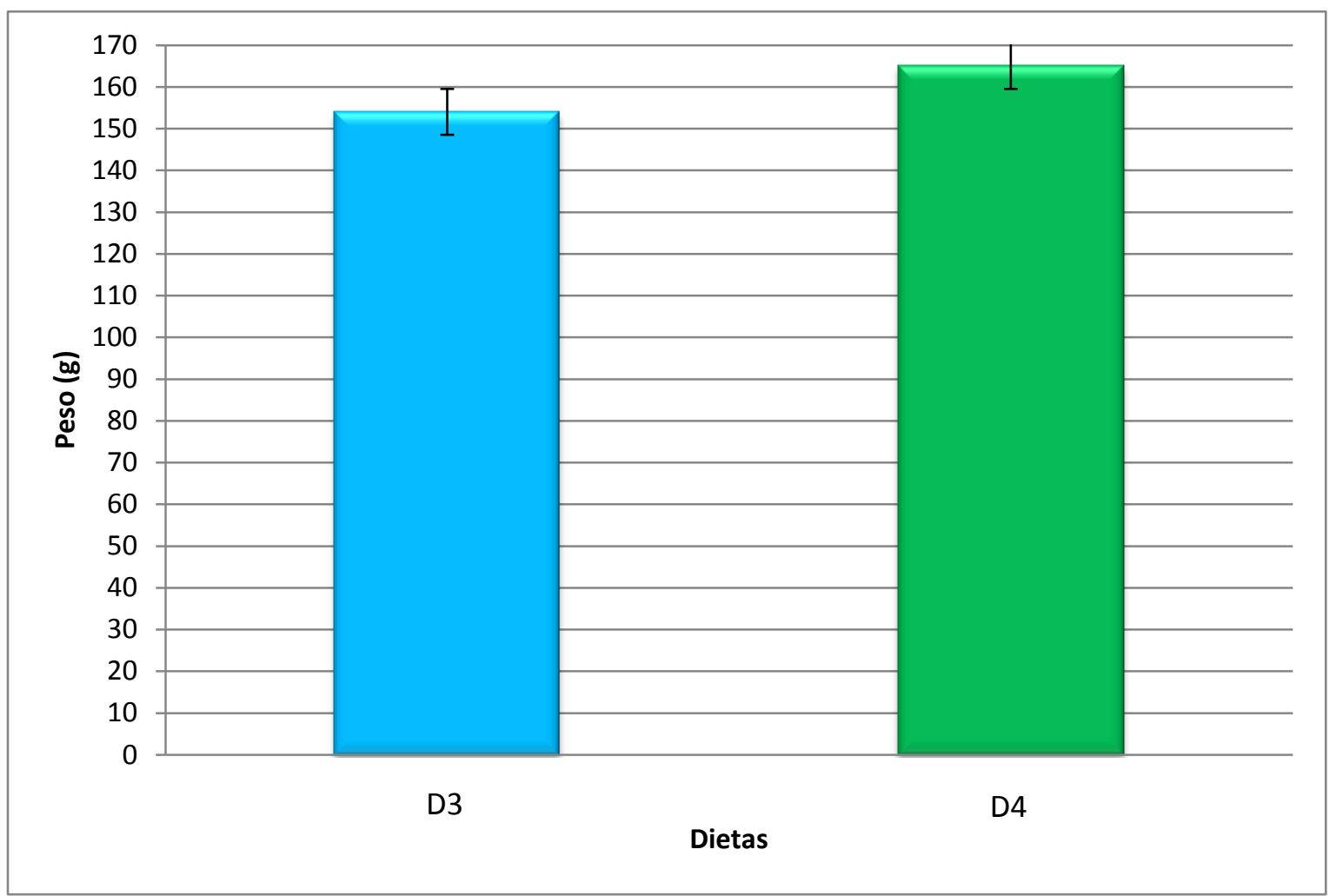

Figura 29: Comparação das médias taxas de preferência (peso em gramas) entre as dietas D3 (dieta proteica não fermentada) e D4 (dieta proteica fermentada) em colônias no campo.

\subsection{Determinação da eficiência de dietas proteicas em} colônias de abelhas africanizadas no campo através do monitoramento, peso e mapeamento.

Após avaliarmos e compararmos as dietas (D3 e D4) montamos um experimento com as colônias no campo. Neste experimento utilizamos seis núcleos padronizados, em relação à quantidade de quadros de cria e quadros de alimento, sendo que dois desses núcleos utilizamos para colocar a dieta D3 (núcleos 1 e 2), dois núcleos com a dieta $\mathrm{D} 4$ (núcleos 3 e 4 ) e o restante serviu como controle, sem alimentação artificial (núcleos 5 e 6). Foi fornecido para cada núcleo 100 gramas de cada dieta (D3 e D4) uma vez por semana, durante 30 dias, com exceção dos núcleos estabelecidos como controle. 
Ao analisarmos os dados obtidos através do mapeamento das colônias, observando a área de cria juntamente com o peso total da colônia, verificamos que o núcleo 1, que foi alimentado com a dieta D3, houve um aumento não significante em relação a área de cria aberta (CA), e cria operculada $(\mathrm{CO}), \mathrm{p}=0,100$. Sendo que no início do mapeamento (dia 0 ) estava com: CA: 8,33\% e CO: $14,05 \%$ de células do favo, e no final do experimento terminou com: CA: 28,57\% e CO: 27,74\% de células do favo (Figura 30).

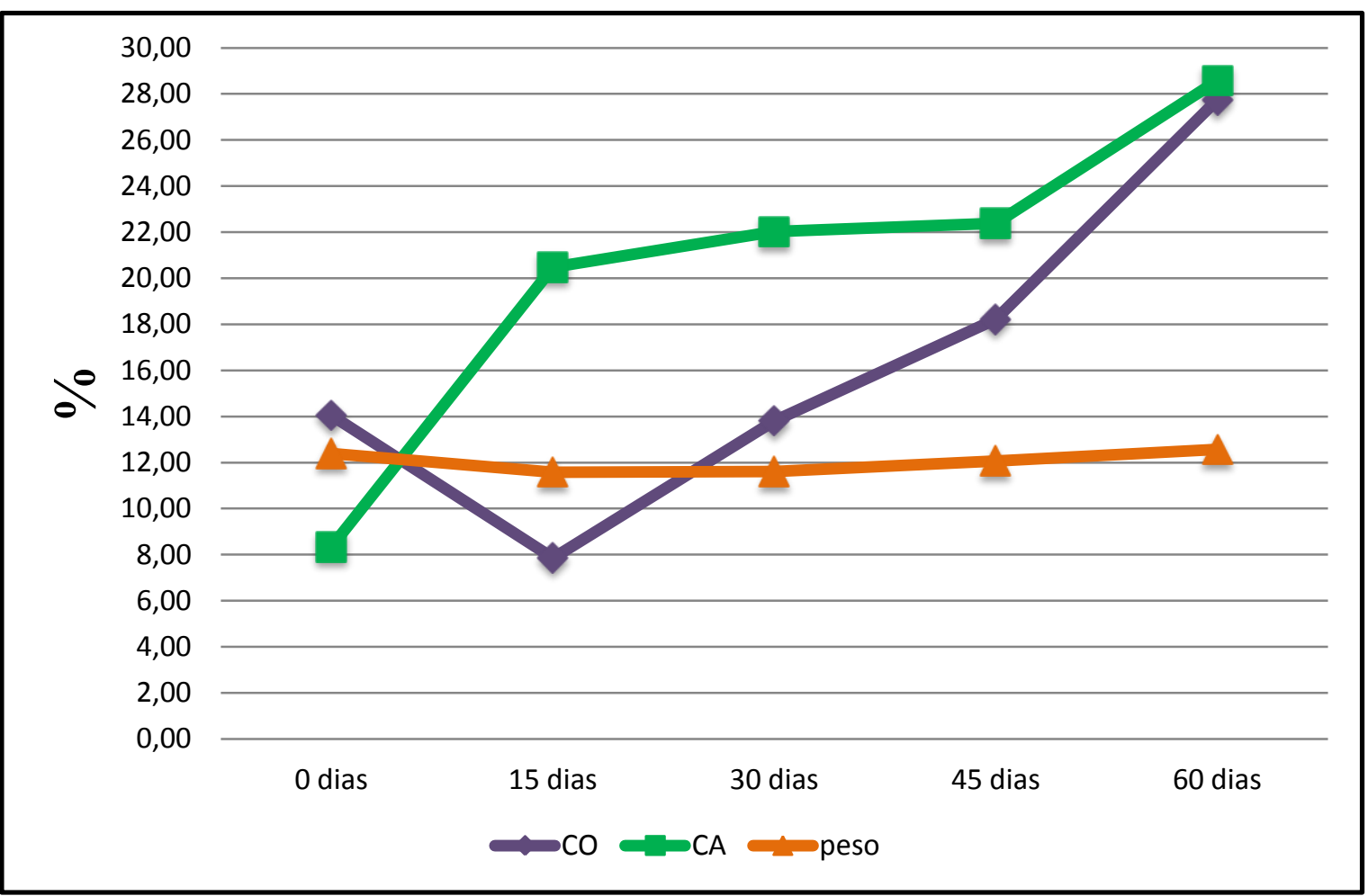

Figura 30: Núcleo 1, alimentado com a dieta D3 (dieta não fermentada), no qual estão representados os dados coletados (\% de área total de favo disponível) através de um mapeamento realizado quinzenalmente referente à quantidade de células dos favos de cria operculada (CO), quantidade de células dos favos de cria aberta (CA) e peso do núcleo, que foi monitorado por balanças digitais.

Ao analisarmos a figura 30, percebemos que a colônia que já estava em condições aceitáveis, tanto em quantidade de cria aberta quanto em cria operculada, após receber a alimentação artificial (dieta D3) obteve um pequeno aumento de peso (de 22,400 Kg no dia 0 para 22,570 Kg no dia 60), e sua área total de cria aumentou consideravelmente. Nossos dados estão de acordo com os 
encontrados por Turcatto, 2011 onde uma colônia alimentada com uma dieta artificial pode ter um aumento em sua área de cria.

Em relação ao núcleo 2, que também foi alimentado com a dieta D3, notamos um pequeno aumento, porém não significativo, $\mathrm{p}=0,12$ na área total de cria nos primeiro quinze dias de mapeamento (de 25,83\% de células do favo no dia 0 para $31,43 \%$ de células do favo no $15^{\circ}$ dia de experimento). Porém mesmo com a colocação da alimentação artificial (Dieta D3), houve um decréscimo significativo na quantidade total de cria e no peso total da colônia, ocorrendo assim uma enxameação por abandono (Figura 31).

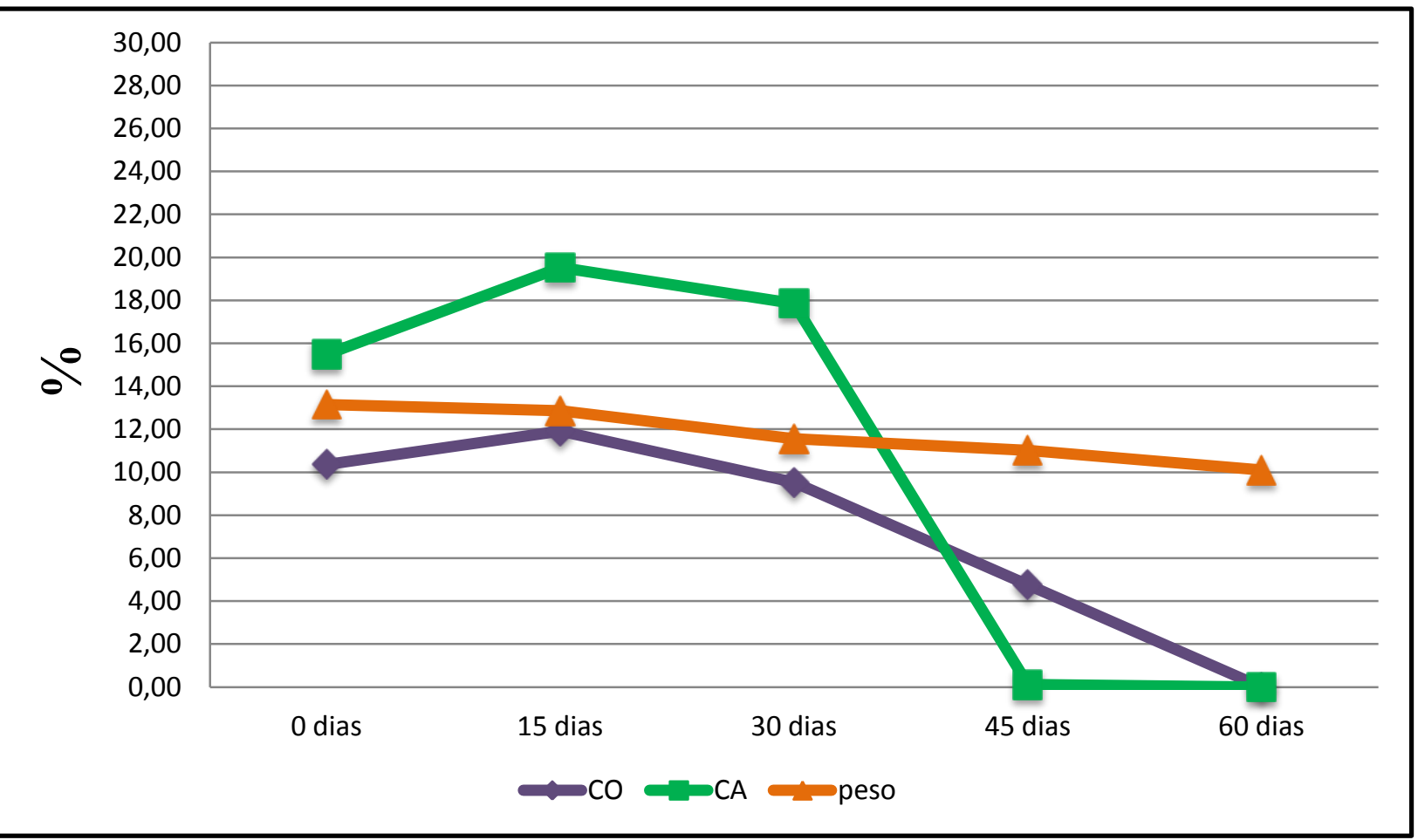

Figura 31: Núcleo 2, alimentado com a dieta D3 (dieta não fermentada), no qual estão representados os dados coletados (\% de área total de favo disponível) através de um mapeamento realizado quinzenalmente referente à quantidade de células dos favos de cria operculada (CO), quantidade de células dos favos de cria aberta (CA) e peso do núcleo, que foi monitorado por balanças digitais. 
Segundo Mattila e Otis, 2006; Nabors, 2000 e Standifer et al., 1973, as dietas como substitutos de pólen podem ser eficazes para manter as colônias nos períodos de escassez, e podem ser capazes de manter a postura da rainha, mas para isso devem ser nutritivas e palatáveis para as abelhas. Sendo assim, observando o consumo da dieta D3 e as taxas de preferência, podemos dizer que a dieta D3 não foi tão palatável a essas abelhas, pois elas enxamearam antes do final do experimento. Porém, em períodos de escassez, onde não há nenhum alimento disponível na natureza, a Dieta D3 poderia ser utilizada, pois conseguiu manter, por um curto período, as colônias alimentadas com ela.

Nos dados obtidos a partir do mapeamento da área de cria do núcleo $\mathbf{3}$, o qual foi alimentado com a dieta $\mathbf{D} 4$, podemos observar que houve um pequeno aumento em relação à área de cria operculada (no dia 0 , havia 27,55\% de células de cria operculada e no último dia (Dia 60) 33,21\% de células de cria operculada. Já os dados analisados em relação a cria aberta, houve um aumento significante, de 16,19\% de células no primeiro dia de mapeamento (Dia 0), para 44,29\% de células de cria aberta. Nossos dados corroboram com os de Hagedorn e Moeller, 1968 onde verificaram que pequenas colônias alimentadas com suplementos artificiais produziram mais crias.

Segundo Hebert e Shimanuk, 1979, as colônias de abelhas A. mellifera precisam de uma alimentação proteica para produzir cria, pois a falta desta tende a diminuir a área de cria na colônia. Dessa maneira, um dos métodos mais utilizados para determinar a eficiência das dietas suplementares é baseado na determinação da área de cria (Herbert et al., 1970).

Ao observarmos o peso total da colônia, houve um aumento do primeiro dia de experimento até o último (de 11,970 Kg para 16,500 Kg) (Figura 32). 


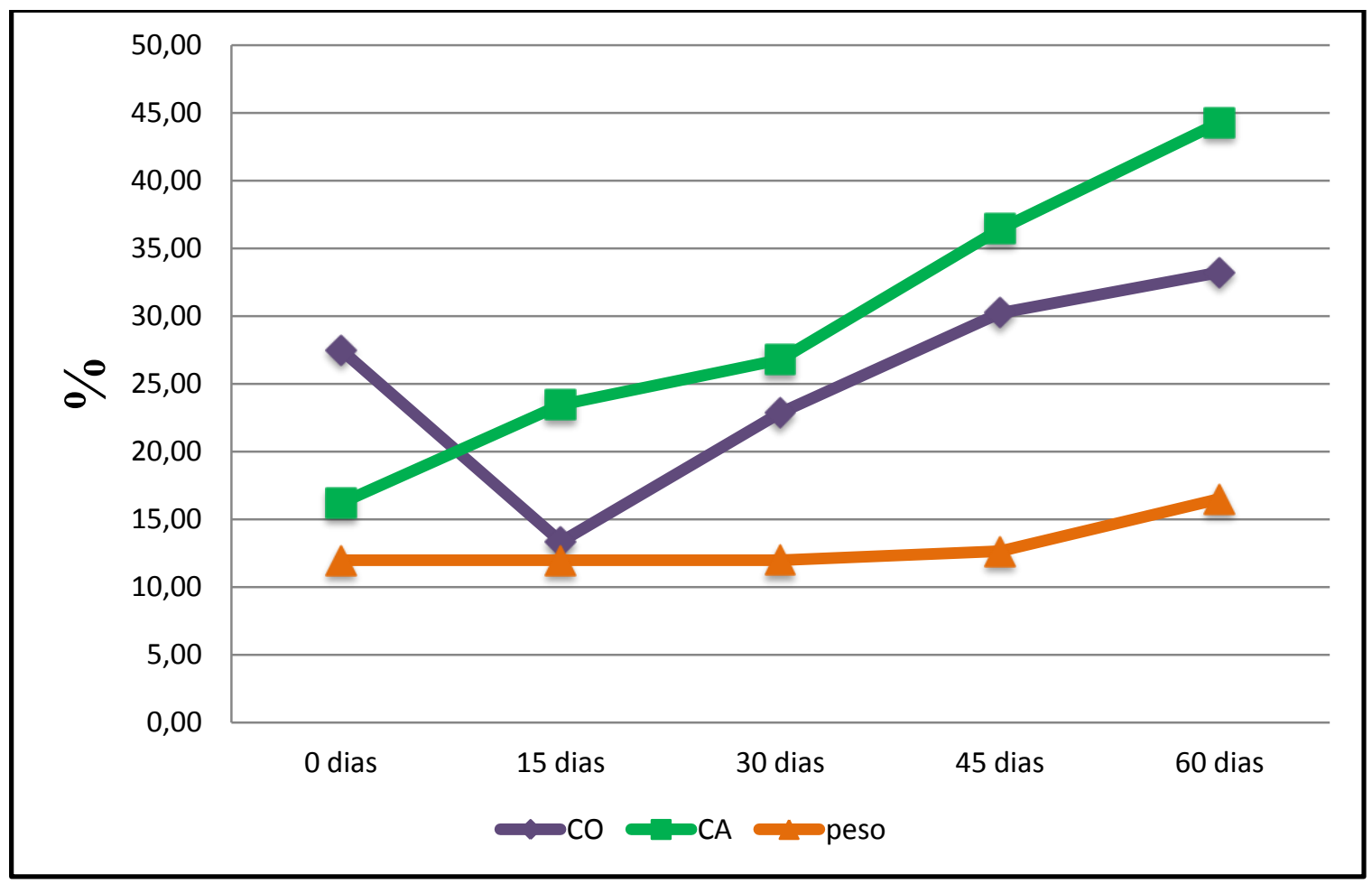

Figura 32: Núcleo 3, alimentado com a dieta D4 (dieta fermentada), no qual estão representados os dados coletados (\% de área total de favo disponível) através de um mapeamento realizado quinzenalmente referente à quantidade de células dos favos de cria operculada (CO), quantidade de células dos favos de cria aberta (CA) e peso do núcleo, que foi monitorado por balanças digitais.

O núcleo 4, alimentado com a dieta $\mathbf{D} 4$, obteve um grande aumento de população, sendo necessário passar esse núcleo para um outro tipo de colônia, um ninho, que possui dez quadros de favos, e não mais como era (cinco quadros), para que essa colônia não enxameasse por enxameação reprodutiva. Assim seu peso aumentou significativamente (de $13,720 \mathrm{Kg}$ no início do mapeamento, para $24,640 \mathrm{Kg}$ no final do mapeamento). A queda em relação à cria operculada do $45^{\circ}$ dia ao $60^{\circ}$ dia, pode ser justificada em razão de termos adicionado mais cinco quadros de favos vazios para que a colônia não enxameasse, como foi dito acima. Após a passagem de núcleo para ninho, ocorrido no $45^{\circ}$ dia, a rainha aumentou sua postura, consequentemente aumentando a área de cria aberta, de 8,69\% de células no início do mapeamento para 44,11\% de células no final do mapeamento. (Figura 33). A área de cria 
aumentou durante o mapeamento, mostrando que o alimento proteico promove o aumento da postura da rainha (Herbert e Shimanuk, 1979).

Nossos dados estão de acordo com Doull, 1980, onde a alimentação artificial mostra correlação positiva com o aumento da área de cria e produtividade da colônia.

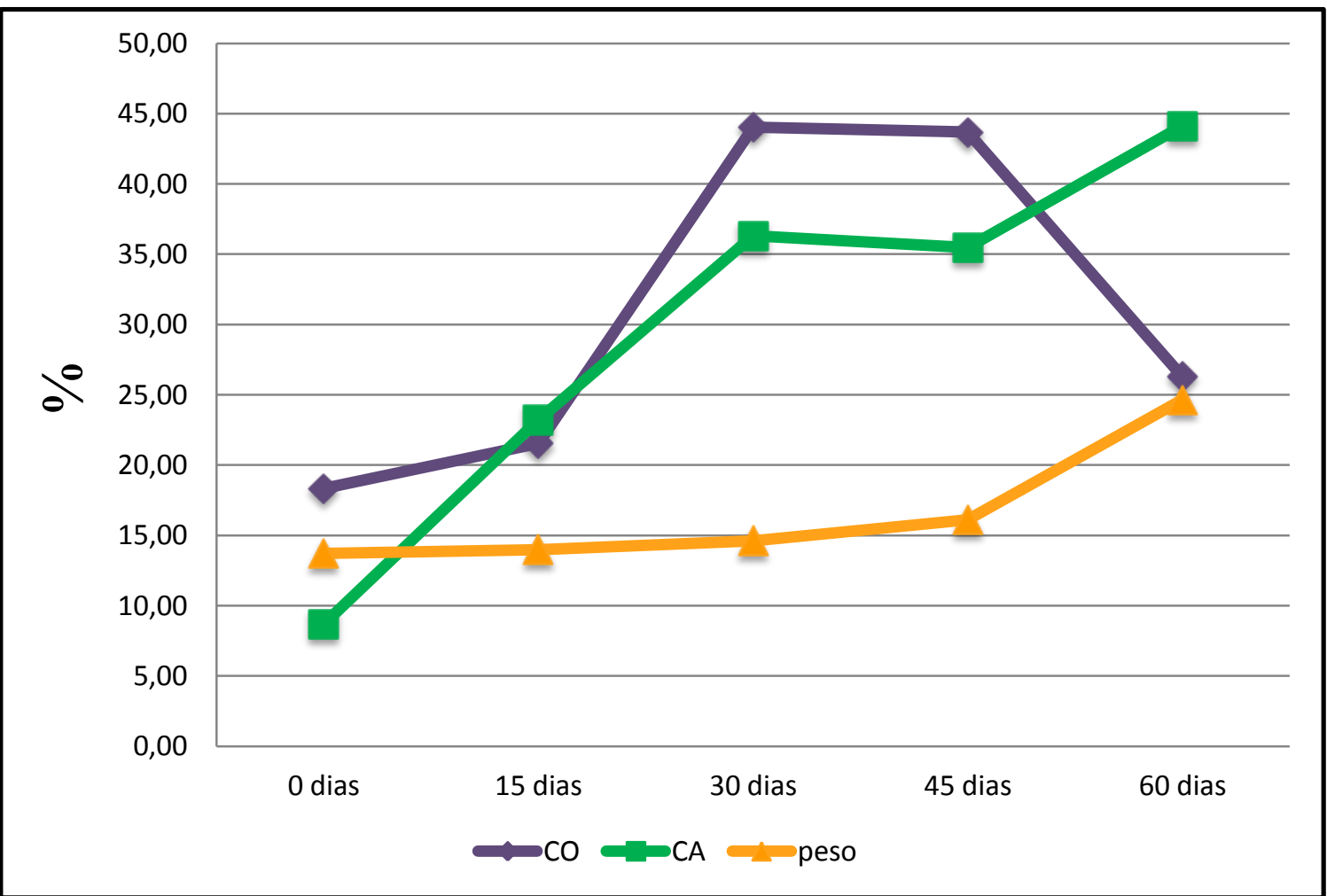

Figura 33: Núcleo 4, alimentado com a dieta D4 (dieta fermentada), no qual estão representados os dados coletados (\% de área total de favo disponível) através de um mapeamento realizado quinzenalmente referente à quantidade de células dos favos de cria operculada (CO), quantidade de células dos favos de cria aberta (CA) e peso do núcleo, que foi monitorado por balanças digitais.

Os núcleos $\mathbf{5}$ e $\mathbf{6}$ que foram denominados controles, ou seja, que não receberam nenhum tipo de alimentação artificial, foram mapeados a partir dos mesmos critérios dos núcleos anteriores discutidos (núcleo 1, 2, 3 e 4).

Allen e Jefree (1956) consideraram que tanto o tamanho da colônia, quanto a quantidade de pólen estocado influenciam o desenvolvimento das crias. Moeller, 1958 verificou que existem vários fatores que afetam a produção de cria, 
tais como a população da colônia, disponibilidade de alimento na natureza e área disponível nos favos. Brandeburgo e Gonçalves, 1989 mostraram que fatores climáticos também influenciam o desenvolvimento de crias.

Ao analisarmos os resultados obtidos do mapeamento do núcleo $\mathbf{5}$ (Figura 34), podemos perceber uma queda brusca na porcentagem de cria operculada no $45^{\circ}$ dia para o $60^{\circ}$ dia, sendo que esta colônia no final do mapeamento continuou com a mesma quantidade de cria operculada que no início (dia 0), mostrando que não houve uma melhora contínua e permanente na área de $\mathrm{CO}$. Os dados referentes ao peso mostraram que não houve um aumento significativo, sendo que no início do experimento esse núcleo pesava 12,820 $\mathrm{Kg}$ e no final do experimento $\left(60^{\circ} \mathrm{dia}\right)$ o peso foi para $13,140 \mathrm{Kg}$. Já em relação a área de CA, houve um pequeno aumento, de 13,10\% de células, para 19,5\% de células (dia 60).

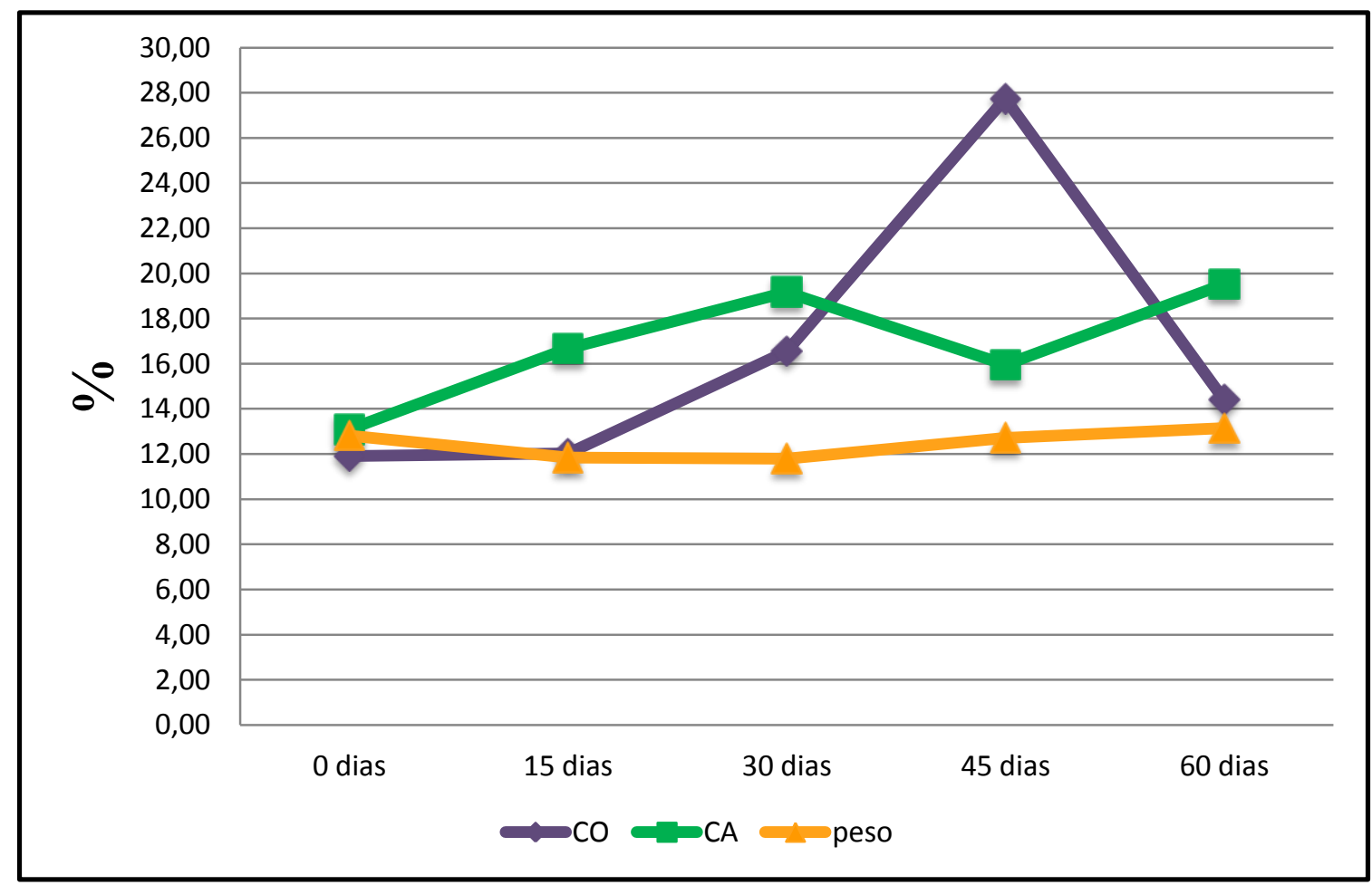

Figura 34: Núcleo 5, colônia controle, no qual estão representados os dados coletados (\% de área total de favo disponível) através de um mapeamento realizado quinzenalmente referente à quantidade de células dos favos de cria operculada $(\mathrm{CO})$, quantidade de células dos favos de cria aberta (CA) e peso do núcleo, que foi monitorado por balanças digitais. 
Através do mapeamento do núcleo 6, podemos observar que essa colônia sofreu várias oscilações referente as áreas de cria (CO e CA). O peso desse núcleo se manteve estável durante todo o experimento. Ao observarmos a Figura 35, verificamos uma queda brusca de cria operculada (de 22,14\% no dia 30 , para $15,6 \%$ no dia 60 ) e de cria aberta (de $21,79 \%$ no dia 30 , para $13,1 \%$ no dia 60), a partir do $30^{\circ}$ dia de mapeamento um decréscimo em relação à cria operculada (de 16,79\% no primeiro dia de experimento, para 15,6\% no último dia). Nossos dados dão força àqueles encontrados por Turcatto, 2011 onde colônias não alimentadas com dietas artificiais em períodos de escassez sofrem um declínio nas áreas de cria.

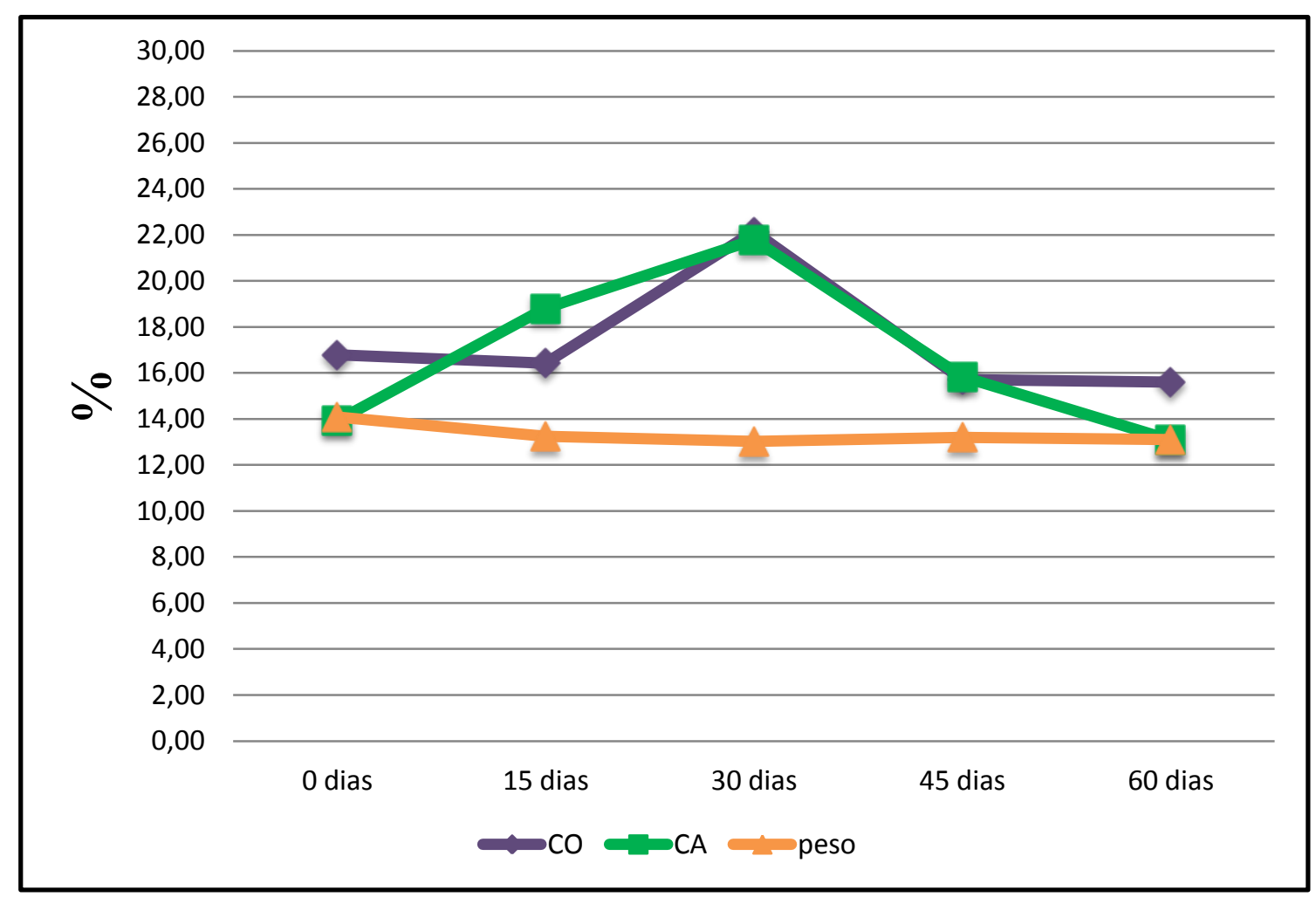

Figura 35: Núcleo 6, colônia controle, no qual estão representados os dados coletados (\% de área total de favo disponível) através de um mapeamento realizado quinzenalmente referente à quantidade de células dos favos de cria operculada (CO), quantidade de células dos favos de cria aberta (CA) e peso do núcleo, monitorado por balanças digitais. 
Ao analisarmos os resultados obtidos nos dois núcleos controles (5 e 6), percebemos que nossos dados concordam com os encontrados por Cremonez, 1996 que mostram que algumas colônias mesmo não recebendo suplementação artificial, podem se manter em condições até a melhora dos recursos naturais.

Após algum tempo sem alimentação que possa suplementar nutricionalmente essas abelhas, dependendo apenas de recursos naturais disponíveis, essas colônias conseguem se manter por um curto período. As abelhas compensam a deficiência de pólen diminuindo a quantidade de cria através da redução da postura da rainha, ou por canibalismo de larvas jovens (Schmickl e Crailsheim, 2001). Nossos dados encontrados nos núcleos do grupo controle assemelham-se com aos encontrados por Hebert et al., 1977, pois pudemos observar que o declínio da área de cria aberta indica a falta de postura da rainha.

Após a análise de todos os núcleos utilizados no mapeamento, notamos que se compararmos os resultados de ambos, os núcleos que consumiram a dieta D4 (fermentada), possuíram um maior aumento do que aqueles que consumiram a dieta $\mathbf{D} 3$ (não fermentada), e esses resultados diferem estatisticamente, $p=0,001$. A área de cria total daqueles que consumiram a dieta D4 possui diferença estatística em comparação com os núcleos que não receberam nenhum tipo de alimentação, o grupo controle (núcleos 5 e 6), $\mathrm{p}=0,013$. Resultados semelhantes aos nossos, no presente estudo, já haviam sido reportados anteriormente por Nation e Robinson, 1971, onde as colônias alimentadas com suplementos proteicos produziram mais crias que aquelas que não receberam. No presente estudo, os núcleos 1 e 2, que receberam a dieta D3, analisando a área de cria total, não foi diferente estatisticamente daqueles do grupo controle, $\mathrm{p}=0,333$ (Figura 36). 


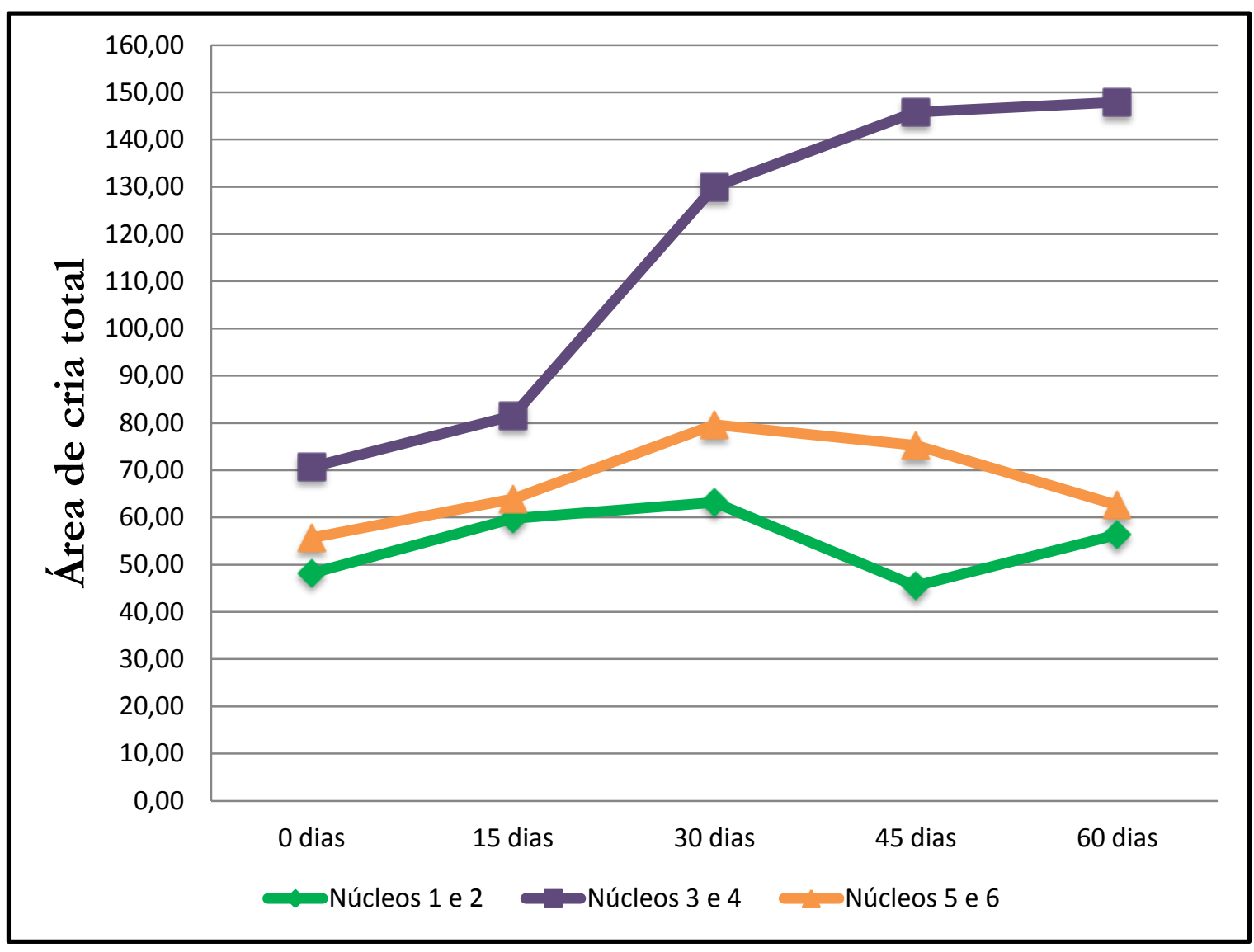

Figura 36: Área de cria total (cria operculada e cria aberta) dos núcleos analisados através do mapeamento quinzenal. Núcleos 1 e 2: alimentados com a dieta D3 (não fermentada); Núcleos 3 e 4: alimentados com a dieta D4 (fermentada); Núcleos 5 e 6: não alimentados com nenhuma dieta artificial (controle).

$\mathrm{Na}$ prática, os apicultores percebem que as abelhas têm baixas reservas de pólen e uma quantidade inadequada de proteína, observando a quantidade da área de cria. Durante a temporada de boas reservas de pólen, a produção de crias de zangão é ativa, e quando as reservas de pólen são baixas, pode-se notar a falta das larvas de zangão (Turcatto, 2011). Segundo Morse, 1975, as abelhas removem e consomem as larvas de operárias desoperculadas, deixando apenas as crias operculadas. Sendo assim, o fornecimento de dietas suplementares para colônias durante os períodos de escassez de alimento na natureza é muito importante, já que uma colônia com limitação de nutrientes essenciais, como as proteínas, apresentará um declínio na produção de cria e não poderá sobreviver se não for fornecido algum alimento suplementar nessa época. 
Alem disso, colônias mal nutridas podem ser um dos fatores determinantes para as perdas dessas colônias (Oldroyd, 2007; Naug e Gibbs, 2009). 


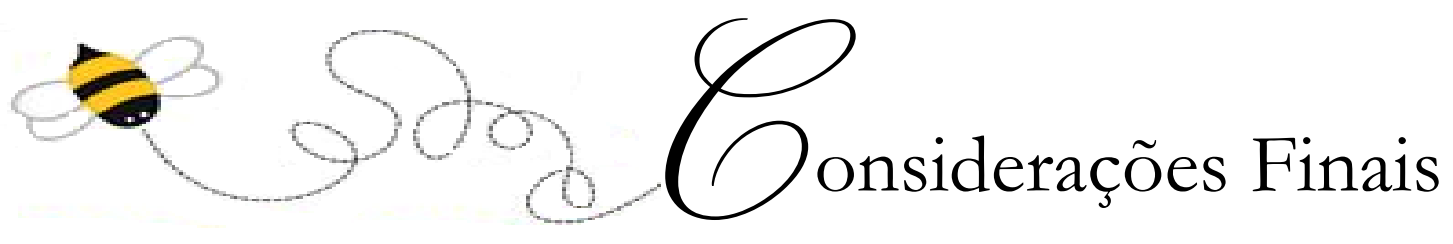




\section{Considerações Finais}

A redução da oferta de alimento na natureza, em diferentes estações, é refletida na diminuição do título de proteína na hemolinfa de operárias adultas de abelhas Apis mellifera. $\mathrm{O}$ alimento armazenado nessa época de escassez pelas colônias não é suficiente para permitir que as abelhas alcancem os títulos normais de proteína observados nas operárias que se desenvolvem em condições de fartura de alimento.

Os testes laboratoriais de quantificação de proteína total em abelhas confinadas mostraram ser eficientes para avaliar as dietas proteicas analisadas.

Observamos que a Dieta D3 (a base de levedura de cana, farinha de soja, farelo de arroz e açúcar) e a Dieta D4 (a base de levedura de cana, farinha de soja, farelo de arroz, açúcar e isca para fermentação), mostraram um bom resultado quando comparadas ao controle positivo e apresentaram diferença estatística em relação ao controle negativo, ou seja, apresentaram médias no nível proteico no hemolinfa superiores às abelhas alimentadas apenas com o xarope. Podemos dizer que essas dietas são semelhantes ao "Beebread" (Controle Positivo), sendo assim boas para suprirem as necessidades nutricionais das abelhas em épocas de escassez.

O perfil proteico da hemolinfa das operárias tratadas com as dietas artificiais D3 e D4 foi semelhante ao perfil das operárias alimentadas com "Beebread" (D1 - Controle Positivo).

Porém, ao analisarmos a expressão da proteína Vitelogenina (Vg) na hemolinfa das abelhas alimentada, os dados obtidos mostram que a densidade das bandas de $\mathrm{Vg}$ da dieta D4 possui diferença estatística em relação aos encontrados da dieta D3. Concluímos então que, as operárias confinadas e alimentadas com a Dieta D4 expressaram normalmente uma das principais proteínas de estocagem, a Vg, melhor às alimentadas com a Dieta D3. Em 
relação à expressão da proteína conhecida como Lipoforina, observamos que as abelhas alimentadas com ambas às dietas (D3 e D4) a expressaram normalmente.

Concluímos que tanto as abelhas alimentadas com a dieta D3, D4 ou com Beebread (Controle Positivo) sobrevivem mais tempo do que as abelhas alimentadas apenas com xarope (controle negativo) nas gaiolas plásticas de confinamento, mantidas em estufa.

Em relação aos testes feitos em colônias no campo, baseados no consumo de cada núcleo, concluímos que entre os núcleos que foram alimentados com as dietas D3 e D4, as abelhas consumiram em maior quantidade a dieta D4, mostrando ser mais palatável uma dieta fermentada (D4) do que uma que não possui tal característica (D3).

Ao colocarmos as duas dietas (D3 e D4) ao mesmo tempo em núcleos no campo, notamos que não há uma preferência por uma ou outra, pois ambas são consumidas.

Concluímos que as colônias alimentadas com a dieta proteica D3, ao analisarmos sua área de cria total, poderia ter sido mais conclusiva se tivéssemos um maior número de colônias para as repetições, pois como o núcleo 2 enxameou, não pudemos analisá-lo até o último dia de experimento.

Porém mesmo assim, observamos que os núcleos alimentados com a dieta D4 tiveram um aumento maior na área de cria e no peso, em relação ao alimentados com a dieta D3 e os núcleos do grupo controle.

Sendo assim, podemos concluir que em épocas de escassez alimentar, onde os apicultores perdem grandes quantidades de colônias, diminuindo assim o rendimento familiar, dietas artificiais proteicas fermentadas, como a dieta $\mathrm{D} 4$ que foi estudada, de fácil acesso ao apicultor, por ser fermentada com o próprio "Beebread" encontrados nas colmeias, além de serem mais palatáveis as abelhas, diminuem os riscos de enxameação por abandono, mantendo essas colônias estáveis até o período de florada, podendo até mesmo elevar os pesos dessas colmeias. 


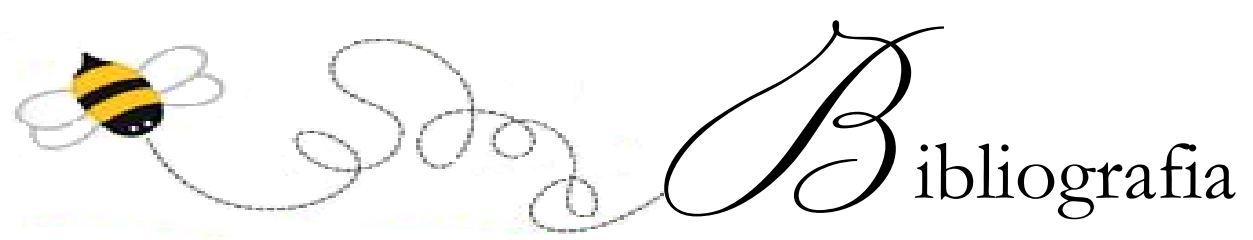




\section{Bibliografia}

ABBAS, T.; ABID, H. \& ALI, R. 1995. Black gram as a pollen substitute for honey bees. Animal Feed Science and Technology 54: 357-359

ALLEN, M. D. \& JE $\square$ REE, E. P. 1956. The influence of stored pollen and colony size on the brood rearing of honey bees. Annals of Applied Biology 44: 649656.

AL-TIKRITY, W. S.; HILLMANN, R. C.; BENTON, A. W. \& CLARKE JR., W. W. 1971. A new instrument for brood measurement in a honey colony. American Bee Journal 111: 20-26.

AMDAM, G. V.; SIMÕES, Z. L. P.; HAGEN, A.; NORBERG, K.; SCHRODER, K.; MIKKELSEN, O.; KIRKWOOD, T. B. L. \& OMHOLT, S. W. 2004. Hormonal control of the yolk precursor vitellogenin regulates immune function and longevity in honeybees. Experimental Gerontology 39: 767773.

AMDAM, G. V.; AASE, A. L.; SEEHUUS, S. C.; FONDRK, M. K.; NORBERG, K. \& HARTFELDER, K. 2005. Social reversal of immunosenescence in honey bee workers. Experimental Gerontology 40: 939947.

AZEVEDO-BENITEZ, A. L. G. \& NOGUEIRA-COUTO, R. H.. 1998. Estudo de algumas dietas artificiais visando à produção de geleia real em colônias de Apis mellifera. In: III ENCONTRO SOBRE ABELHAS, Ribeirão Preto, SP, 227-230.

BARKER, R. J. \& LEHNER, Y. 1974. Acceptance and sustenance value of naturally occurring sugars fed to newly emerged adult workers of honey bees (Apis mellifera L.). Journal of Experimental Zoology 187: 277-285. 
BITONDI, M. M. G. \& SIMÕES, Z. L. P. 1996. The relationship between level of pollen in the diet, vitellogenin and juvenile hormone titres in Africanized Apis mellifera workers. Journal of Apicultural Research 35: 27-36.

BITONDI, M. M.; NASCIMENTO, A. M.; CUNHA, A. D.; GUIDUGLI, K. R.; NUNES, F. M. \& SIMÕES, Z. L. 2006. Characterization and expression of the Hex 110 gene encoding a glutamine-rich hexamerin in the honeybee, Apis mellifera, Arch. Insect Biochemistry Physiology 63: 57-72.

BRADFORD, M. M. 1976. A rapid and sensitive method for the quantitation of microgram quantities of protein utilizing the principle of protein-dye binding. Analytical Biochemistry 72: 248-254.

BRANDEBURGO, M. A. M. \& GONÇALVES, L. S. 1989. A influência de fatores ambientais no desenvolvimento de colônias de abelhas africanizadas (Apis mellifera). Revista Brasileira de Biologia 49: 1035-1038.

BRODSCHNEIDER, R. \& CRAILSHEIM, K. 2010. Nutrition and health in honey bees. Apidologie 41: 278-294.

CARISEY, N. \& BAUCE, E. 1997. Impact of balsam fir flowering on pollen and foliage biochemistry in relation to spruce budworm growth, development and food utilization. Entomologia Experimentalis et Applicata 85: 17-31.

CRAILSHEIM, K. 1990. The protein balance of the honey bee worker. Apidologie 21: 417-429.

CRAILSHEIM, K. 1991. Interadult feeding of jelly in honeybee (Apis mellifera L.) colonies. Journal of Comparative Physiology 161B: 55-60.

CRAILSHEIM, K. 1998. Trophallactic interactions in the adult honeybee (Apis mellifera L.), Apidologie 29: 97-112.

CRAILSHEIM, K.; SCHNEIDER, L. H. W.; HRASSNIGG, N.; BÜHLMANN, G.; BROSCH, U.; GMEINBAUER, R. \& SCHÖFFMANN B. 1992. Pollen 
consumption and utilization in worker honeybees (Apis mellifera carnica): dependence on individual age and function. Journal Insect Physiology 38: 409-419.

CRANE, E. 1977. Dead bees under lime trees. Sugars poisonous to bees. Bee World 58: 129-130.

CRANE, E. 1978. Sugars poisonous to bees. Bee World 59: 37-38.

CREMONEZ, T. M. 1996. Avaliação de métodos para determinação da eficiência de dietas proteicas em abelhas Apis mellifera. Dissertação de Mestrado apresentada à FFCLRP-USP, Ribeirão Preto, 103 p.

CREMONEZ, T. M. 2001. Influência da nutrição sobre aspectos da fisiologia e nutrição de abelhas Apis mellifera. Tese de Doutorado apresentada à FFCLRPUSP, Ribeirão Preto, 87 p.

CREMONEZ, T. M.; DE JONG, D. \& BITONDI, M. M. G. 1998. Quantification of hemolymph proteins as a fast method for testing protein diets for honey bees (Hymenoptera: Apidae). Journal of Economic Entomology 91: 12841289.

COUTO, L. A. 1998. Nutrição de abelhas. In: XII CONGRESSO BRASILEIRO DE APICULTURA, Salvador. BA, 92-95.

CUNHA, A. D.; NASCIMENTO, A. M.; GUIDUGLI, K. R.; SIMÕES, Z. L. \& BITONDI, M. M. 2005. Molecular cloning and expression of a hexamerin cDNA from the honeybee, Apis mellifera. Journal of Insect Physiology 51: 11351147.

DEGRANDI-HOFFMAN, G.; CHEN, Y.; HUANG, E. \& HUANG, H.M. 2010. The effect of diet on protein concentration, hypopharungeal gland development and virus load in worker honey bees (Apis mellifera L). Journal of Insect Physiology 56: 1184-1191.

DE GROOT, A. P. 1953. Protein and amino acid requirements of the honey bee. Physiology Comparative Oecology 3: 1-90. 
DE JONG, D.; SILVA E. J.; KEVAN, P. \& ATKINSON, J. L. 2009. Pollen substitutes increase honey bee hemolymph protein levels as much as or more than does pollen. Journal of Apicultural Research 48: 34-37.

DETZEI, A. \& WINK, M. 1993. Attraction, deterrence or intoxication of bees (Apis mellifera) by plant allelochemicals. Chemoecology 4: 8-18.

DOULL, K. M. 1980. Relationships between consumption of a pollen supplement, honey production and broodrearing in colonies of honey bees Apis mellifera L. Apidologie 11: 367-374.

ELLIS, A. \& HAYES JR, G. W. 2009. An evaluation of fresh versus fermented diets for honey bees (Apis mellifera). Journal of Apicultural Research and Bee World 48: 215-216.

FOOTE, H. L. 1957. Possible use of microorganisms in synthetic bee bread production. American Bee Journal 97: 476-478.

FREE, J. B. 1980. A organização social das abelhas (Apis) E.P.U., EDUSP, São Paulo.

FREITAS, B. M. 1991. Potencial da caatinga para a produção de pólen e néctar para exploração apícola. Dissertação de Mestrado apresentada à Universidade Federal do Ceará, Fortaleza, 140 p.

GILLIAM, M. 1979. Microbiology of pollen and bee bread: the yeasts. Apidologie 10: 43-53.

GILLIAN, M. 1997. Identification and rules of non-pathogenic microflora associated with honey bees. FEMS Microbiology Letters 155: 1-10.

GREGORY, P. G. 2006. Protein diets and their effects on workers weight, longevity, consumption and hemolymph protein levels of Apis mellifera. Proceedings of the American Bee Research Conference, 2006. http://ars.usda.gov/SP2Userfiles/Place/64133000/PDFFILES/427ABJ\%20146.pdf 
GONÇALVES, N. M. 1978. Estudo dos materiais superficiais da região de Ribeirão Preto-SP e suas relações com elementos morfológicos da paisagem. Dissertação de Mestrado apresentada ao Instituto de Geociências-USP, São Paulo, 176 p.

HAGEDORN, H. H. \& MOELLER, F. E. 1968. Effect of the age of pollen used in pollen supplements on their nutritive value for the honeybee. I. Effect on thoracic weight, development of hypopharyngeal glands and brood rearing. Journal of Apicultural Research 7: 89-95.

HAYDAK, M. H. 1958. Pollen - pollen substitutes - beebread. American Bee Journal 98: 145-146.

HAYDAK, M. H. 1963. Influence of storage on the nutritive value of pollen for brood rearing by honeybees. Journal of Apicultural Research 2: 105-107.

HAYDAK, M. H. 1970. Honey Bee Nutrition. Annual Review of Entomology 15: 143-156.

HERBERT JR., E. W. 1992. Honey Bee Nutrition. In The Hive and The Honey Bee. Graham, J. M. (ed), Dadant \& Sons. Hamilton, Illinois, 197-233.

HERBERT, E. W.; BICKLEY, W. E. \& SHIMANUKI, H. 1970. The broodrearing capability of caged honey bees fed dandelion and mixed pollen diets. Journal of Economy Entomology 63: 213-218.

HERBERT JR., E. W; SHIMANUKI, H. \& CARON, D. 1977. Optimum protein levels required by honey bees (Hymenoptera: Apidae) to initiate and maintain brood rearing. Apidologie 8: 141-146.

HERBERT JR., E. W; SHIMANUK, H. 1979. Seasonal protein preferences of free flying colonies of honey bees. American Bee Journal 119: 298-302.

HERBERT JR., E. W. \& SHIMANUKI, H. 1978. Chemical composition and nutritive value of bee collected and bee stored pollen. Apidologie 9: 33-40. 
HRASSNIGG, N. \& CRAILSHEIM, K. 2005. Differences in drone and worker physiology in honeybees (Apis mellifera L.). Apidologie 36: 255-277.

HUANG, Z.Y. 2010. Honey bee nutrition. American Bee Journal 150: 773-776

KELLER, I.; FLURI, P. \& IMDORF, A. 2005. Pollen nutrition and colony development in honey bees: part I. Bee World 86: 1-10.

LAZZARINI, K. R. G. 2006. Expressão gênica das proteínas vitelogenina e lipoforina e seus receptores nas fases vitelogênicas e não vitelogênicas de Apis mellifera. Tese de doutorado apresentada à FMRP - USP, Ribeirão Preto, 159p.

LI, C.; XU, B.; WANG, Y.; FENG, Q. \& YANG, W. 2012. Effects of dietary crude protein levels on development, antioxidant status, and total midgut protease activity of honey bee (Apis mellifera lingustica). Apidologie 43: 576.

LIMA, A. O. N. 1995. Pólen coletado por abelhas africanizadas em apiário comercial na caatinga cearense. Dissertação de Mestrado apresentada à Universidade Federal do Ceará, Fortaleza, 118 p.

MANNING, R.; RUTKAY, A.; EATON, L. \& BERNARD, D. 2007. Lipidenhanced pollen and lipid-reduced flour diets and their effect on the longevity of honey bees (Apis mellifera L.). Australian Journal of Entomology 46: 251-257.

MARTINS, J. R.; NUNES, F. M.; SIMÕES, Z. L. \& BITONDI, M. M. 2008. A honeybee storage protein gene, hex 70a, expressed in developing gonads and nutritionally regulated in adult fat body. Journal of Insect Physiology 54: 867877.

MATTILA, H. R. \& OTIS, G. W. 2006. Effects of pollen availability and Nosema infection during the spring on division of labor and survival of worker honey bees (Hymenoptera: Apidae). Environmental Entomology 35: 708-717.

MELO, A. A.; VALLE, D; MACHADO, E. A.; SALERNO, A.; PAIVASILVA G. O.; CUNHA E SILVA, N. L.; SOUZA, W. \& MASUDA, H. 2000. 
Synthesis of vitellogenin by the follicle cells of Rhodnius prolixus. Insect Biochemistry and Molecular Biology 30: 549-557.

MOELLER, F. E. 1958. Relation between egg-laying capacity of queen bees and population and honey production of their colonies. American Bee Journal 98: 401402.

MORSE, R. A. 1975. Bees and beekeeping. Cornel University Press, Ithaca, NY.

NATION, J. L. \& ROBINSON, F. A. 1971. Concentration of some major and trace elements in honeybees, royal jelly and pollens, determined by atomic absorption spectrophotometry. Journal of Apicultural Research 10: 35-43.

NAUG, D. \& GIBBS, A. 2009. Behavioral changes mediated by hunger in honeybees infected with Nosema ceranae. Apidologie 40: 595-599.

OLDROYD, B. P. \& THOMPSON, G. J. 2007. Behavioral genetics of the honey bee, Apis mellifera. Advances in Physiology Education 33: 1-49.

PEREIRA, F. M.; FREITAS, B. M.; NETO, J. M. V.; LOPES, M. T. R.; BARBOSA, A. L. \& CAMARGO, R. C. R. 2005. Desenvolvimento de colônias de abelhas com diferentes alimentos proteicos. Pesquisa Agropecuária Brasileira 41: $1-7$.

PIAULACHS, M. D.; GUIDUGLI, K. R.; BARCHUK, A. R.; SIMÕES, Z. L. P. \& BELLÉS, X. 2003. The vitellogenin of honey bee. Apis mellifera: structural analysis of the cDNA and expression studies. Insect Biochemistry and Molecular Biology 33: 459-465.

ROUlSTON, T. H. \& CANE, J. H. 2000. Pollen nutritional content and digestibility for animals. Plant Systematics and Evolution 222: 187-209.

SAGILI, R. R. \& PANKIW, T. 2007. Effects of protein-constrained brood food on honey bee (Apis mellifera L.) pollen foraging and colony growth. Behavior Ecology Sociobiology 61: 1471-1478. 
SCHMICKL, T. \& CRAILSHEIM, K. 2001. Cannibalism and early capping: strategy of honeybee colonies in times of experimental pollen shortages. Journal of Comparative Physiology A 187:541-547.

SCHMICKL, T. \& CRAILSHEIM, K. 2002. How honeybees (Apis mellifera L.) change their broodcare behavior in response to non-foraging conditions and poor pollen conditions. Behavior Ecology Sociobiology 51: 415-425.

SCHMIDT, J. O. 1984. Feeding preference of Apis mellifera L. (Hymenoptera: apidae): individual versus mixed pollen species. Journal of the Kansas Entomological Society 57: 323-327.

SCHMIDT, J. O.; THOENES, S. C. \& LEVIN, M. D. 1987. Survival of honey bees, Apis mellifera (Hymenoptera: Apidae), fed various pollen sources. Journal of Economic Entomology 80: 176-183.

SCHMIDT, J. O. \& HANNA, A. 2006. Chemical Nature of Phagostimulants in Pollen Attractive to Honeybees. Journal of Insect Behavior 19: 521-532.

SEELEY, T. D. 1985. Honey bee ecology. Princeton University Press, New Jersey.

SEREIA, M. J. 2009. Suplementos proteicos para abelhas africanizadas submetidas à produção de geleia real. Dissertação de Mestrado apresentada à Universidade Federal de Maringá, Maringá, 92 p.

SOMERVILLE, D. 2005. Fat bees, skinny bees - a manual on honey bee nutrition for beekeepers. NSW Department of Primary Industries. RIRDC Publication No 05/054. www.rirdc.gov.au

STANDIFER, L. N.; HAYDAK, M. H.; MILLS, J. P. \& LEVIN, M. D. 1973. Value of three protein rations in maintaining honey bee colonies in outdoor flight cages. Journal of Apiculture Research 12: 137-143. 
TURCATTO, A. P. 2011. Desenvolvimento e análise do efeito de dietas proteicas como suplementação nutricional para abelhas Apis mellifera. Dissertação de Mestrado apresentada à FFCLRP-USP, Ribeirão Preto, 73 p.

VALLE, D. 1993. Vitellogenesis in insects and other groups - A review. Memórias do Instituto Oswaldo Cruz 88: 1-26.

VAN DER STENN, J. 2007. Effect of hone-made pollen substitute on honey bee colony development. Journal of Apiculture Research 46: 114-119.

WINSTON, M. L.; CHALMERS, W. T. \& LEE, P. C. 1983. Effects of two pollen substitutes on brood mortality and length of adult life in the honey bee. Journal of Apicultural Research 22: 49-52.

WINSTON, M. L. 2003. A biologia da abelha. 1 ed. Magister. Porto Alegre. 276 p. 